AUTARQUIA ASSOCIADA À UNIVERSIDADE DE SÃO PAULO

\begin{abstract}
A APLICABILIDADE DO ÍNDICE DE QUALIDADE DE VIDA, DA PEGADA ECOLÓGICA DO TURISMO E DOS INDICADORES DE SUSTENTABILIDADE DA ORGANIZAÇÃO DAS NAÇÕES UNIDAS PARA DESTINOS TURÍSTICOS DE PEQUENO PORTE: UM ESTUDO DE CASO NO JALAPÃO/TO
\end{abstract}

MARY LÚCIA GOMES SILVEIRA DE SENNA

Tese apresentada como parte dos requisitos para obtenção do Grau de Doutor em Ciências na Área de Tecnologia Nuclear - Materiais

Orientador:

Prof. Dr. Afonso Rodrigues de Aquino

São Paulo 
INSTITUTO DE PESQUISAS ENERGÉTICAS E NUCLEARES

Autarquia associada à Universidade de São Paulo

A APLICABILIDADE DO ÍNDICE DE QUALIDADE DE VIDA, DA PEGADA ECOLÓGICA DO TURISMO E DOS INDICADORES DE

SUSTENTABILIDADE DA ORGANIZAÇÃO DAS NAÇÕES UNIDAS PARA DESTINOS TURÍSTICOS DE PEQUENO PORTE: UM ESTUDO DE CASO NO JALAPÃO/TO

MARY LÚCIA GOMES SILVEIRA DE SENNA

Tese apresentada como parte dos requisitos para obtenção do Grau de Doutora em Ciências na área de Tecnologia Nuclear - Materiais.

Orientador:

Prof. Dr. Afonso Rodrigues de Aquino

Versão Corrigida

Versão Original disponível no IPEN

SÃO PAULO

2016 


\section{DEDICATÓRIA}

Recebi muitos incentivos na minha jornada. Mas, nenhum se compara ao seu. Ele acreditou em mim quando nem mesmo eu fui capaz disso. Mostrou-me que o difícil é mais prazeroso. E assim fui, dia após dia, superando as dificuldades. Suas palavras de apoio me resgatavam das noites turbulentas. Ah, sem você... Obrigada, André Machado de Senna, por mostrar-me o caminho sem volta da vida de estudos e dedicação. Forever and ever...

À minha princesinha encantada, Mariah Silveira de Senna, que entendeu desde os seus três aninhos o que era ter uma mamãe doutoranda. Você trazia água, frutas, desenhos e muito amor para o quarto de estudos para que meus momentos de dedicação a esse projeto fossem suaves. Amarei-te infinitamente!

Com vocês, por vocês e para vocês, dedico-lhes esse trabalho! 


\section{AGRADECIMENTOS}

A conclusão desse trabalho representa uma importante conquista da minha vida. Sem o auxílio de Deus e a intercessão de Nossa Senhora, não seria possível. E Ele colocou alguns anjos na minha vida para que esse projeto fosse concluído. Dessa forma, agradeço:

Ao Professor Dr. Afonso Rodrigues de Aquino pela orientação, que acreditou no projeto em meados de 2012, sempre apoiando, confiando e incentivando esse trabalho. Muito obrigada, professor Afonso, por ajudar-me a transformar 0 sonho em realidade.

Ao Instituto de Pesquisas Energéticas e Nucleares, IPEN e à Universidade de São Paulo pela oportunidade de crescimento profissional e acadêmico.

Aos professores do Doutorado em Ciências que compartilharam seus conhecimentos e com quem muito aprendi.

Ao Instituto Federal de Educação, Ciência e Tecnologia por conceder-me a oportunidade de capacitação e apoio a esta pesquisa.

Aos moradores da região do Jalapão e gestores públicos que me apoiaram na realização deste projeto que tão bem me receberam, acreditando em dias melhores e em um turismo sustentável para a região do Jalapão.

Aos alunos Pedro Messetti, Maria Eugênia Belém, Bernardo Alves de Senna e Amanda Nunes que me auxiliaram nas saídas de campo, sempre atentos e dedicados.

Aos meus amores, André Machado de Senna e Mariah Silveira de Senna, por terem sido os meus companheiros de todas as saídas de campo, que sempre estavam nas horas felizes e tristes ao meu lado dando-me sempre um sorriso amigo após cada dia no sol tocantinense.

À minha mãezinha, Maria Perpétua Gomes da Silveira, que abdicou momentaneamente do conforto do seu lar para ir para Palmas socorrer-me nas horas aflitas e foi a "mãevó" da minha princesinha! 
Ao meu Pai, Antônio Rodrigues da Silveira, in memoriam, que sempre lutou para que sua filha tivesse todas as oportunidades que ele não teve, e que me mostrou que para se ter caráter, dedicação à família, amor ao próximo, fé e coragem eu não precisaria frequentar os bancos das escolas e universidades.

Ao meu irmão, Marco Antônio Gomes da Silveira, que mesmo sem entender o que queria dizer esse complexo universo do doutorado, soube silenciar-se ou abraçar-me no momento certo para que esse projeto fosse adiante!

À minha comadre e prima-irmã, Fátima Silveira Filgueiras, que trouxe sua alegria contagiante e sempre me incentivou a estudar e buscar um lugar melhor ao sol!

A minha segunda família, Machado de Senna, que tão bem me acolheu e que sempre acreditaram o quão capaz eu era. O meu muito obrigada!

Aos meus colegas de área do IFTO que apoiaram incondicionalmente esse projeto e permitiram que eu pudesse dedicar-me a cada etapa dessa conquista. Veruska, Janaína, Daniella, Jaci, Jaimile, Stella, Felipe e Geruza, serei eternamente grata a vocês!

À minha amiga, Veruska Chemet Dutra. Você definitivamente foi uma das poucas pessoas que entendeu minhas angústias, alegrias e vitórias dessa jornada. Soube como ninguém acalmar-me e dar-me "o puxão de orelha" na hora certa! Juntas fizemos uma parceria que será lembrada por toda uma vida! Só posso agradecê-la! Obrigada, obrigada, obrigada! Conte comigo!

A toda família Tolentino, em especial ao meu amigo em Cristo, Carlos Henrique que tanto me ajudou nesse trabalho. Só tenho que agradecer-lhe e a declarar o meu respeito ao seu conhecimento!

A todos aqueles que eu não citei e que, seja com uma palavra simples ou com discussões acerca da pesquisa, muito contribuíram para a realização deste sonho.

A todos vocês o meu muito obrigada! 
O importante não é por quanto tempo viverás, mas que qualidade de vida

terás.

Sêneca 


\title{
A APLICABILIDADE DO ÍNDICE DE QUALIDADE DE VIDA, DA PEGADA ECOLÓGICA DO TURISMO E DOS INDICADORES DE SUSTENTABILIDADE DA ORGANIZAÇÃO DAS NAÇÕES UNIDAS PARA DESTINOS TURÍSTICOS DE PEQUENO PORTE: UM ESTUDO DE CASO NO JALAPÃO/TO
}

\author{
Mary Lúcia Gomes Silveira de Senna
}

\section{RESUMO}

Neste trabalho buscou-se conhecer as perspectivas de sustentabilidade socioambiental no contexto do desenvolvimento do turismo na cidade de Mateiros/Tocantins. Para tanto, foi avaliada a aplicabilidade em destino de pequeno porte dos indicadores de sustentabilidade: Índice de Qualidade de Vida (IQV), Indicadores de Sustentabilidade da Organização das Nações Unidas (ONU) e Pegada Ecológica do Turismo. Percebeu-se que houve um incremento no IQV da cidade de Mateiros de 32,82\% após o estabelecimento do turismo, com destaque para as famílias que atuam na produção das peças de artesanato de capim dourado. A mudança, de 0,162 para 0,215 , indica que apesar de ter havido uma elevação na qualidade de vida das famílias entrevistadas, o IQV permaneceu baixo, isto é, com valores entre zero e 0,499. Tal fato demonstra que a qualidade de vida das famílias não é satisfatória. Quanto à ferramenta da $\mathrm{ONU}$, percebeu-se que não há sistematização de dados suficientes para que esta ferramenta possa ser utilizada pelos órgãos governamentais na captação de recursos e utilização destes para criar novas políticas públicas para a região. Tal fato demonstra uma ineficácia em destinos de pequeno porte que se assemelhem à cidade de Mateiros na forma em que foi utilizado nesse trabalho. Quanto à Pegada Ecológica do Turismo, de acordo com a metodologia proposta, são necessários 2.194,2263 hectares de terras para absorver $\mathrm{O} \mathrm{CO}_{2}$ demandado pela atividade turística na região. A categoria com maior impacto foi terras de energia fóssil na subcategoria transporte terrestre. Conclui-se, então, que os indicadores de sustentabilidade Pegada Ecológica do Turismo e Índice de Qualidade de Vida mostraram-se ferramentas eficazes para se avaliar as perspectivas de sustentabilidade de destinos de pequeno porte.

Palavras-chave: Qualidade de Vida; Pegada Ecológica; Indicadores de Sustentabilidade da Organização das Nações Unidas; Jalapão. 


\title{
APPLICABILITY OF QUALITY OF LIFE INDEX, TOURISM ECOLOGICAL FOOTPRINT AND SUSTAINABILITY INDICATORS OF THE UNITED NATIONS FOR SMALL TOURIST DESTINATIONS: A CASE STUDY IN JALAPÃO/TO
}

\author{
Mary Lúcia Gomes Silveira de Senna
}

\begin{abstract}
This work aimed to investigate the possibilities for environmental sustainability in the context of tourism development in the community of Mateiros/Tocantins. Therefore, we evaluated the applicability of sustainability indicators in small tourist destination: Quality of Life Index (QLI), Sustainability Indicators of the United Nations and Tourism Ecological Footprint. It was concluded that there was an increase in the Quality of Life Index of Mateiros's community of $32.82 \%$ after the establishment of tourism, especially for families who work in the production of "capim dourado" handicrafts. The changes from 0.162 to 0.215 indicates that although there was a rise in the quality of life of the families interviewed, QLI remained low, that is, with values between zero and 0,499 . This shows that the families' quality of life is not satisfactory. As the UN tool, it was noticed that there is not systematic enough data. So the tool proposed by the UN can't be used by government agencies to create new public policies for the region. This fact demonstrates the ineffectiveness of its use in small destinations that are similar to the city of Mateiros. As for the Ecological Footprint of Tourism, according to the proposed methodology, it is needed 2194.2263 hectares of land to absorb $\mathrm{CO}_{2}$ demanded by tourism in the region. The category with the greatest impact is fossil energy land in sub ground transportation. It was concluded, then, that the Tourism Ecological Footprint and Quality of Life Index were effective sustainability indicators tools to evaluate small destinations.
\end{abstract}

Keywords: Quality of Life; Ecological Footprint; Sustainability Indicators of the United Nations; Jalapão. 


\section{SUMÁRIO}

Página

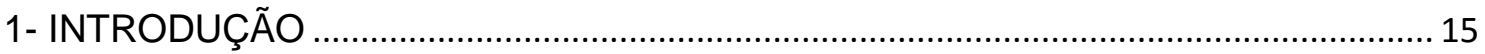

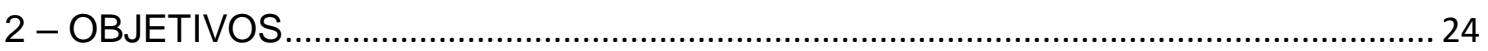

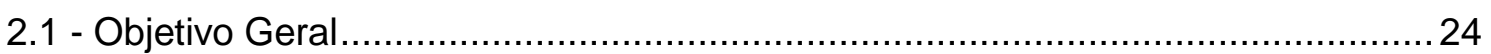

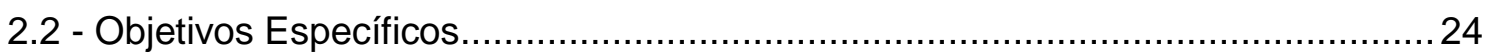

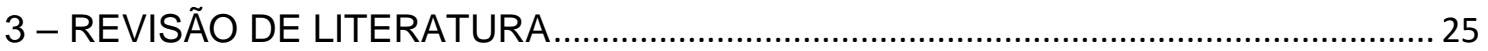

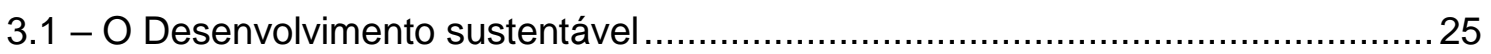

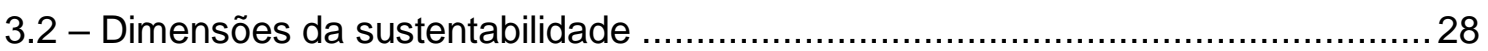

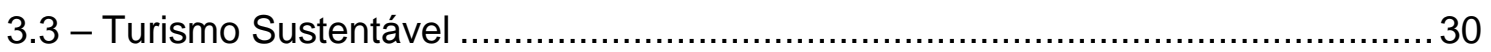

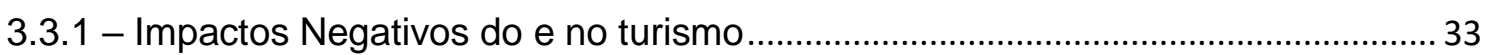

3.3.1.1 - Impactos econômicos negativos do turismo......................................................... 33

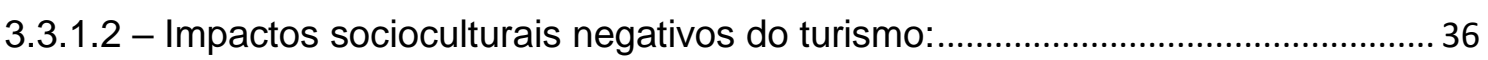

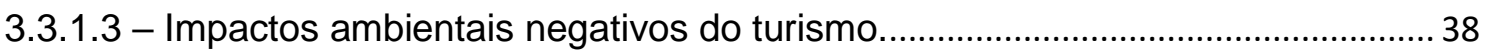

3.3.1.4 - Impactos Ambientais Globais que podem afetar o Turismo .............................. 41

3.3.2 - Impactos Positivos do Turismo Sustentável ......................................................... 42

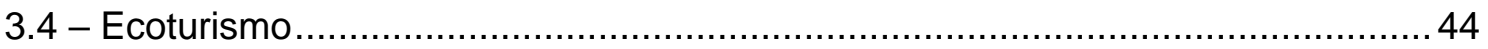

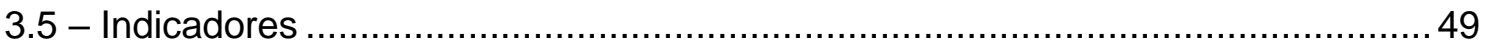

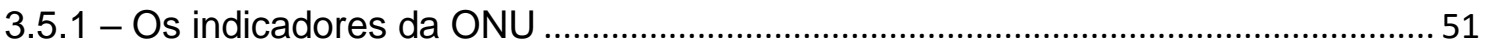

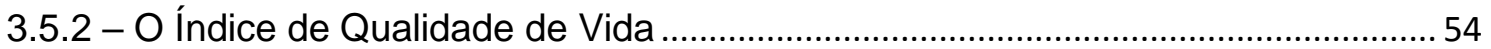

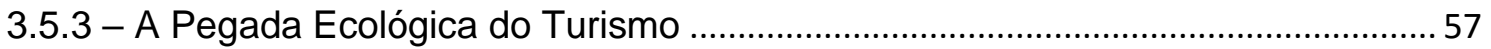

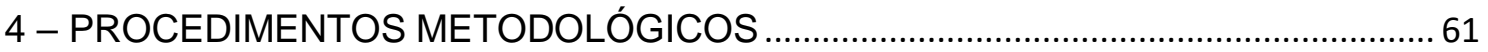

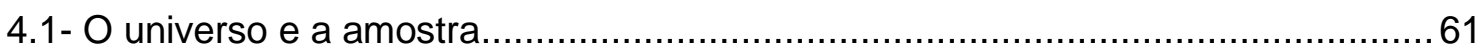

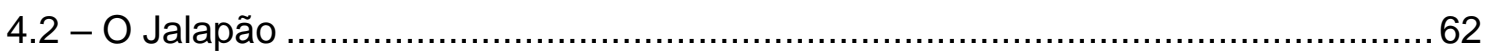

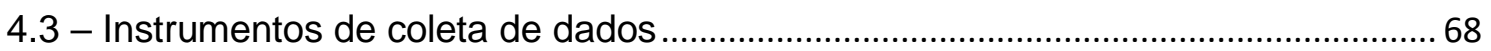

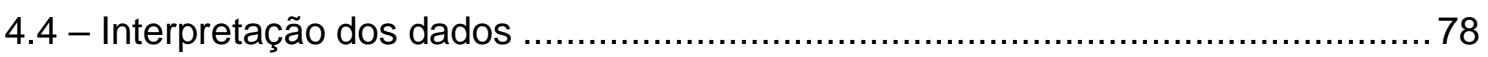

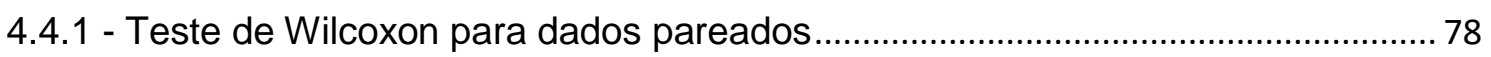

4.4.2 - Teste de Mann-Withney para 2 amostras independentes ........................................ 79

4.4.3 - Teste de Kruskal-Wallis para k amostras independentes ..................................... 80

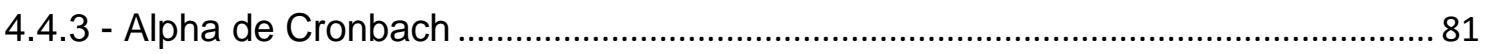

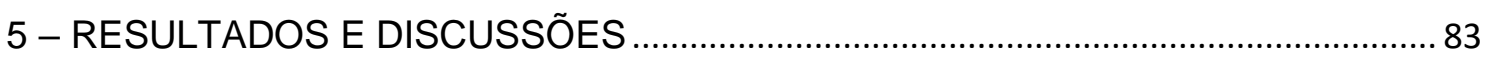

5.1 - Análise dos Indicadores da Organização das Nações Unidas. ..................... 83

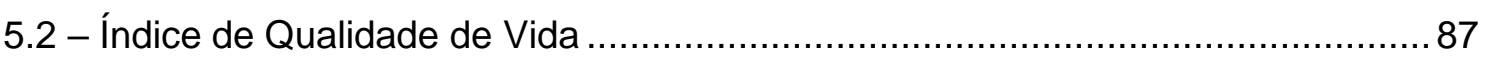

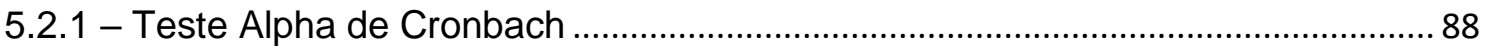

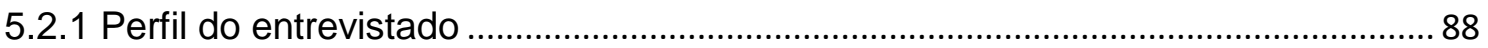




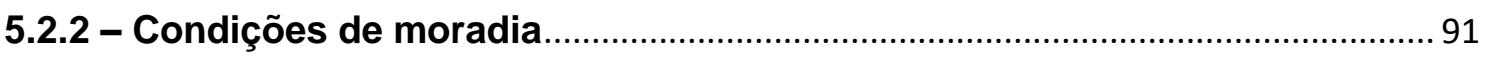

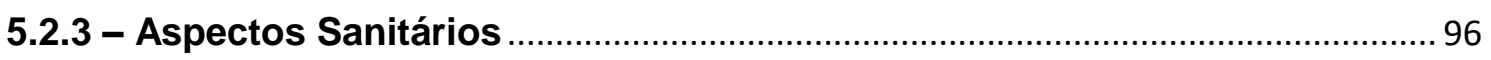

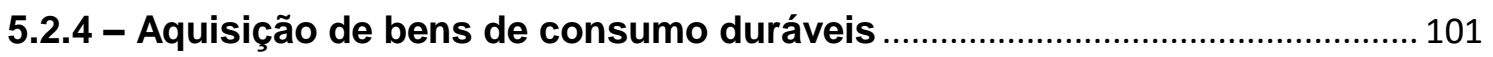

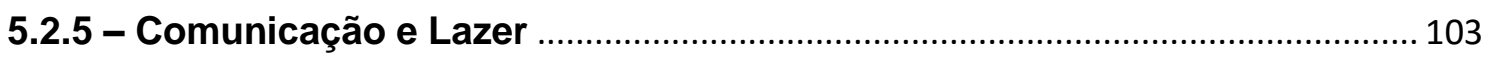

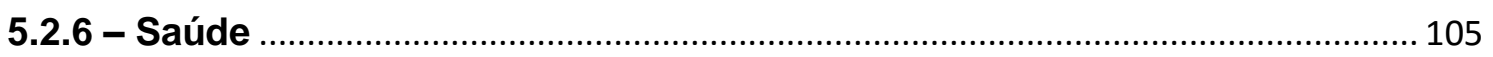

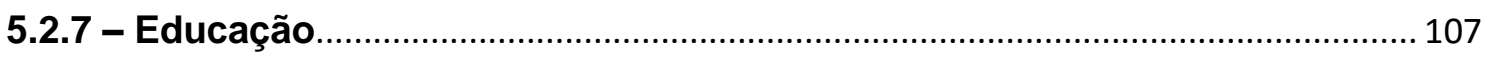

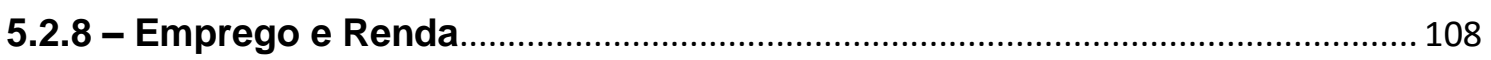

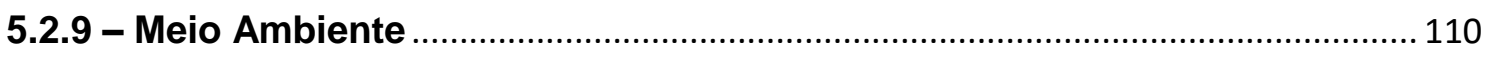

5.2.10 - Consolidação dos dados do Índice de Qualidade de Vida de Mateiros. 111

5.2.11 - Análise comparativa das variáveis do Índice de Qualidade de Vida de

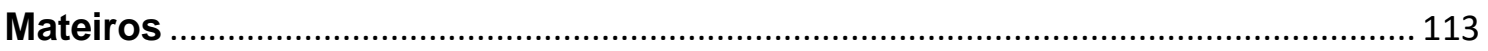

5.3 - Cálculo da Pegada Ecológica do Turismo. .............................................. 117

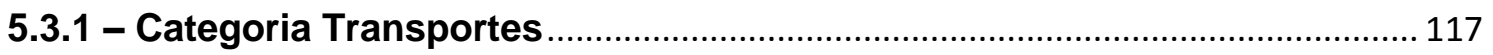

5.3.1.1 - Categoria Transporte - Subcategoria Terras Construídas. ...................... 117

5.3.1.2 - Categoria Transporte - Subcategoria Terras de Energia Fóssil............. 119

5.3.1.2.1 - Subcategoria Terras de Energia Fóssil Transporte Aéreo ...................... 120

5.3.1.2.2 - Subcategoria Terras de Energia Fóssil Transporte Terrestre ............... 123

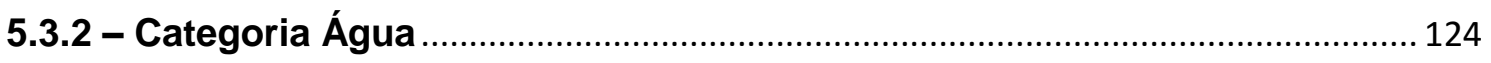

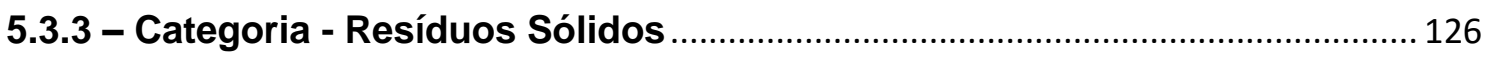

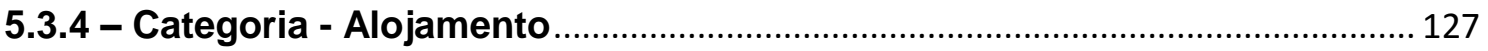

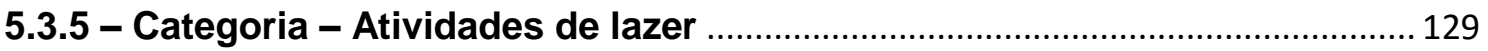

5.3.6 - Categoria - Alimentação e consumo de fibras ............................................ 130

5.3.7 - Pegada Ecológica do Turismo de Mateiros …................................................. 131

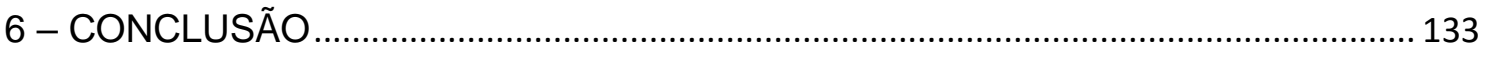

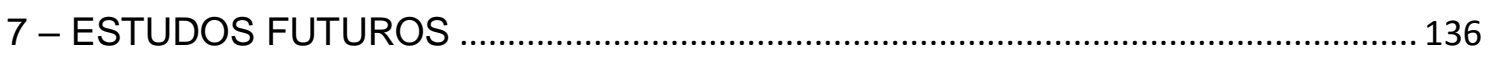

APÊNDICE A - Questionário Indicadores Ambientais ONU ........................................... 137

APÊNDICE B - Questionário Indicadores Econômicos ONU ........................................... 141

APÊNDICE C - Questionário Indicadores Sociais ONU................................................. 144

APÊNDICE D - Questionário para entrevista por residência IQV ................................... 148

APÊNDICE E - Questionário Prefeitura/NATURATINS - Pegada Ecológica do Turismo

APÊNDICE F - Questionário Pousada/Camping - Pegada Ecológica do Turismo .... 157

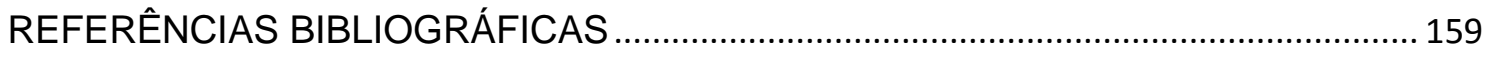




\section{LISTA DE TABELAS}

Tabela 3.1: Características do ecoturismo ativo e passivo 47

Tabela 4.1: Indicadores considerados em cada dimensão selecionada para composição do IQV 70

Tabela 4.2 - Indicadores das Nações Unidas 72

Tabela 4.3: Procedimentos para cálculo da Pegada Ecológica do Turismo 74 Tabela 5.1: Alpha de Crombach por indicador considerando separadamente os dois momentos da pesquisa 88

Tabela 5.2 - Valores dos indicadores e do IQV, obtidos na cidade de Mateiros (TO), antes e após o estabelecimento da atividade turística 112 Tabela 5.3: Frequência absoluta e relativa das variáveis da amostra e média, mediana, desvio padrão mínimo e máximo da variável idade

Tabela 5.4: Média, mediana, desvio padrão, mínimo e máximo de IQV antes, depois e da diferença (depois - antes) seguido do p-valor do teste de Wilcoxon pareado para diferença entre os momentos de avaliação

Tabela 5.5: média, mediana e desvio padrão de IQV antes e depois e diferença para cada categoria das variáveis sexo, idade, escolaridade, atividade turismo e bolsa família, seguidos do p-valor do teste de Mann-Whitney e Kruskal-Wallis.

Tabela 5.6: Medições das distâncias e larguras da estrada de Mateiros até os atrativos da região 119

Tabela 5.7: Conversão entre unidades de valores na categoria transportes....... 119 Tabela 5.8: Estimativa de distância total voada da origem à Palmas 122 Tabela 5.9: Distância total voada por passageiro-quilômetro para Palmas 122 Tabela 5.10: Resumo dos cálculos categoria transporte aéreo: terras de energia fóssil 123

Tabela 5.11: Resumo dos cálculos categoria transporte terrestre: terras de energia fóssil 124

Tabela 5.12: Resumo dos cálculos categoria água 125

Tabela 5.13: Resumo dos cálculos categoria resíduos sólidos 127

Tabela 5.14: Resumo dos cálculos categoria alojamentos: terras construídas 128

Tabela 5.15: Resumo dos cálculos categoria alojamentos: terras de energia fóssil 129

Tabela 5.16: Áreas construídas nos atrativos turísticos 130 


\section{LISTA DE FIGURAS}

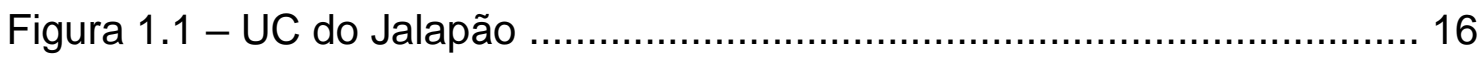

Figura 1.2 - Atrativos Turísticos - Parque Estadual do Jalapão ...................... 18

Figura 3.1: Princípios fundamentais do ecoturismo ...................................... 46

Figura 4.1 - Mapa da cidade de Mateiros dividido por regiões em que foram

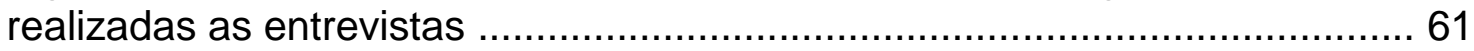

Figura 4.2: Distribuição dos biomas brasileiros e área de inserção do Projeto

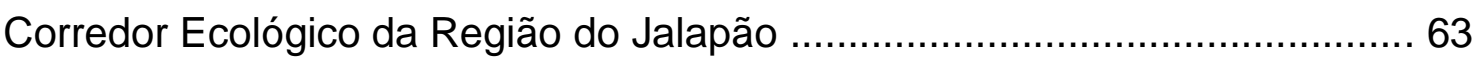

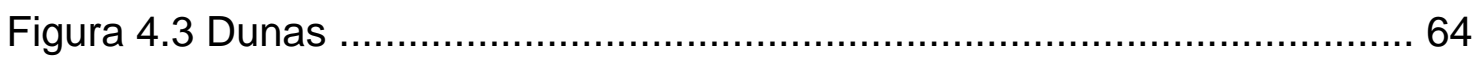

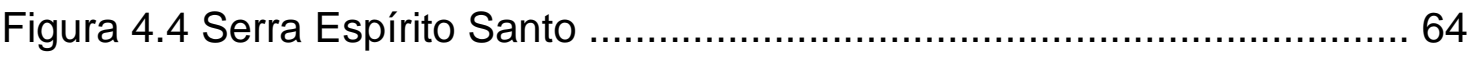

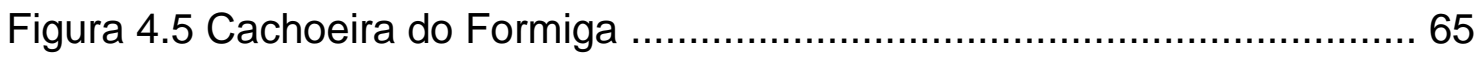

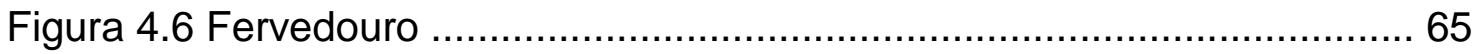

Figura 4.7 - Mapa com acessos à cidade de Mateiros / Jalapão .................... 66

Figura 4.8 - Condições da estrada via São Félix do Tocantins em setembro de

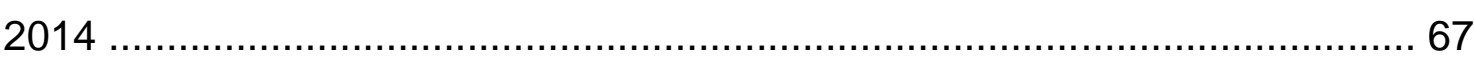

Figura 5.1 - Entrevista com a Secretária de Administração, Planejamento e

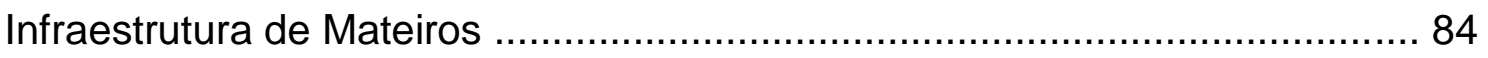

Figura 5.2: Entrevista com artesã de Mateiros ………............................. 87

Figura 5.3 - Atuantes e não atuantes com atividades ligadas ao turismo ....... 89

Figura 5.4 - Número de pessoas na casa que atuam com atividades ligadas ao

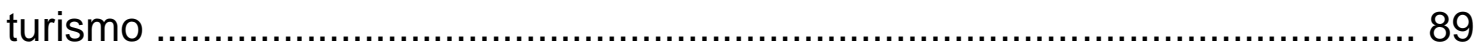

Figura 5.5 - Em que ano o entrevistado começou a trabalhar na atividade .... 89

Figura 5.6- Já trabalhava antes de atuar com turismo ................................. 89

Figura 5.7 - Idade do entrevistado ....................................................... 90

Figura 5.8- Estado Civil antes e depois do turismo ..................................... 90

Figura 5.9 - Quantas pessoas moram em sua residência? ........................... 91

Figura 5.10 - Quantos filhos você tem? ................................................. 91

Figura 5.11 - Situação de posse de sua moradia ........................................ 92

Figura 5.12 - Tipo de construção do domicílio ................................................93

Figura 5.13 - Piso do domicílio ................................................................ 94

Figura 5.14 - Tipo de iluminação do domicílio ............................................. 95

Figura 5.15 - Grau de satisfação com as condições de moradia .................... 95 
Figura 5.16 - Destino dado aos dejetos humanos segundo relato dos

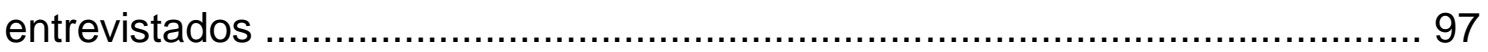

Figura 5.17 - Destino do lixo domiciliar ...................................................... 98

Figura 5.18 - Coleta do resíduo sólido de Mateiros. .................................... 98

Figura 5.19 - Origem da água para consumo humano .................................. 99

Figura 5.20 - Tratamento dada a água para consumo ................................... 99

Figura 5.21: Água saindo da torneira de um morador entrevistado ............... 101

Figura 5.22: Condição do tecido colocado na torneira para impedir acesso da

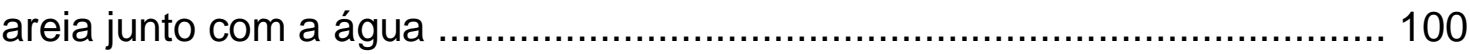

Figura 5.23 - Grau de satisfação com as condições sanitárias .................... 101

Figura 5.24 - Acesso a bens de consumo duráveis ................................... 102

Figura 5.25 - Grau de satisfação em relação ao acesso a bens de consumo

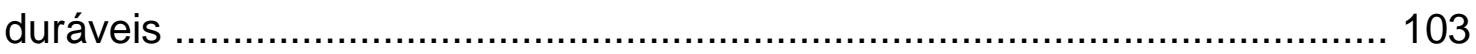

Figura 5.26 - Acesso aos meios de comunicação ..................................... 104

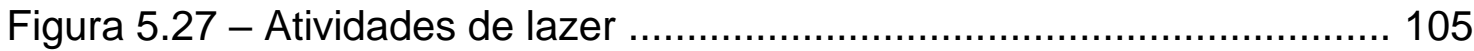

Figura 5.28 - Prestação de serviços de saúde na cidade ............................ 106

Figura 5.29 - Grau de instrução do entrevistado ......................................... 107

Figura 5.30 - Grau de satisfação em relação ao nível de educação da família 108

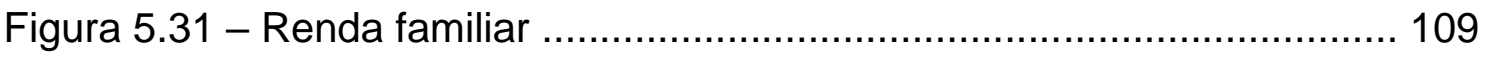

Figura 5.32 - Fonte de Renda das famílias de Mateiros/TO ........................ 109

Figura 5.33 - Famílias que utilizam o turismo para complementar a renda .. 110 Figura 5.34 - Situações que são percebidas com relação ao meio ambiente 111 Figura 5.35 - Grau de satisfação em relação a preservação do meio ambiente local 111

Figura 5.36 - Valores dos Indicadores e do IQV de antes e depois do turismo das famílias que atuam com turismo 112 Figura 5.37 - Valores dos Indicadores e do IQV de antes e depois do turismo de todas as famílias entrevistadas 113 Figura 5.38 - Distribuição de turistas por região 121 


\section{LISTA DE SIGLAS}

ADTUR - Agência de Desenvolvimento Turístico do Tocantins

APA - Área de Proteção Ambiental

ATS - Agência Tocantinense de Saneamento

$\mathrm{CH}_{4}-$ Gás Metano

$\mathrm{CO}_{2}$ - Dióxido de Carbono

CST - Certificacion para la Sostenibilidad Turística

DBO - Demanda Bioquímica por Oxigênio

EF - Ecological Footprint

GJ - Gigajoule

IBAMA - Instituto Brasileiro do Meio Ambiente e dos Recursos Renováveis

IBGE - Instituto Brasileiro de Geografia e Estatística

ICSU - Conselho Internacional de Uniões Científicas

IDH - Índice de Desenvolvimento Humano

IDHM - Índice de Desenvolvimento Humano Municipal

IFTO - Instituto Federal de Educação, Ciência e Tecnologia do Tocantins

IPCC - Intergovernmental Panel on Climate Change

IPEN - Instituto de Pesquisas Energéticas e Nucleares

IQV - Índice de Qualidade de Vida

LAC - Limite Aceitável de Câmbio

MJ - Megajoule

$\mathrm{ML}$ - Megalitro

MMA - Ministério do Meio Ambiente

MTUR - Ministério do Turismo

MWh - Megawatt-hora

NATURATINS - Instituto Natureza do Tocantins

NEATUS - Núcleo de Estudos Ambientais e Turismo Sustentável

ODM - Objetivos do Desenvolvimento do Milênio

OECD - Organization for Economic Co-operation and Developement

OMT - Organização Mundial do Turismo

ONG - Organização não-governamental

ONU - Organização das Nações Unidas

PE - Pegada Ecológica 
PEJ - Parque Estadual do Jalapão

PET - Pegada Ecológica do Turismo

PIB - Produto Interno Bruto

PNB - Produto Nacional Bruto

PNUD - Programa de Desenvolvimento das Nações Unidas

PNUMA - Programa das Nações Unidas para o Meio Ambiente

PROECOTUR - Programa de Desenvolvimento do Ecoturismo da Amazônia Legal SECOM - Secretaria de Comunicação Social

SEPLAN - Secretaria do Planejamento do Meio Ambiente

TEF - Tourism Ecological Footprint

TEFM - Tourism Ecological Footprint Method

TO - Tocantins

UC - Unidade de Conversação

UNEP - United Nations Environment Programme

UNESCO - Organização das Nações Unidas para a Educação, a Ciência e a Cultura UFT - Universidade Federal do Tocantins

WCED - World Commission on Environment and Development

WWF - World Wide Fund 


\section{1- INTRODUÇÃO}

O conceito de sustentabilidade perpassa por duas linhas que em sua origem são distintas, mas que podem se cruzar em busca do bem comum. $O$ primeiro conceito refere-se à biologia ou ecologia que trata da capacidade de recuperação e reprodução do ecossistema (resiliência) frente às agressões antrópicas com o uso abusivo de recursos naturais, desflorestamentos, fogo, dentre outros ou ainda os naturais como terremotos, tsunamis, etc. A segunda linha diz respeito a aspectos ligados à economia, desenvolvimento e à expansão cada vez maior do padrão de consumo e a finitude dos recursos naturais (NASCIMENTO, 2012).

Aquino et al. (2014) abordaram as dimensões da sustentabilidade como sendo: Dimensão Ambiental, a qualidade ambiental deve ser buscada incessantemente para que haja um melhor aproveitamento de suas riquezas pelas futuras gerações; Dimensão Institucional, que por meio de ações políticas seja possível o investimento em ciência e tecnologia, além de exigir uma atuação do poder público para a fiscalização e proteção do meio ambiente; Dimensão Social que prevê a diminuição das desigualdades sociais por meio de criação de postos de trabalho para que haja uma qualidade de vida da população; e Dimensão Econômica que analisa a influência do desempenho econômico sobre a sustentabilidade.

E exatamente para mensurar essas dimensões de sustentabilidade que foram pensados os indicadores. Soares, Medeiros e Sales Filho (2013) citaram a conceituação de indicadores segundo a Organization for Economic Cooperation and Developement (OECD) como sendo um conjunto de parâmetros ou valor derivado de parâmetro que apontam significado para um fenômeno com uma extensão representativa. Concluindo o conceito, os autores consideram que indicadores podem ser considerados como variáveis que 
juntas, podem representar um quadro de referências que, quando analisados trarão a realidade de uma dada região geográfica.

A região do Jalapão, no leste do Estado do Tocantins, compreende uma área espacial de 53,3 mil km², que faz divisa com os estados Maranhão, Piauí e Bahia. Desta área total, 34,1 mil $\mathrm{km}^{2}$ encontram-se dentro do Estado do Tocantins. Possui uma baixa densidade populacional (entre 0,3 e 0,7 hab./km²).

As Unidades de Conservação (UC) que encontram no Parque Estadual do Jalapão (PEJ) são um importante elo de conexão são Estação Ecológica Serra Geral do Tocantins com área de 716 mil hectares, Área de Proteção Ambiental do Jalapão (APA) com 467 mil hectares, APA Serra da Tabatinga e o Parque Nacional Nascentes do Parnaíba com quase 730 mil hectares de área. O conjunto de UCs do Jalapão forma uma das maiores regiões de Cerrado sob proteção ambiental (SCHMIDT, 2005), como pode ser visto na FIG. 1.1.

Mosaicos de Unidades de Conservação Região do Jalapão - Tocantins

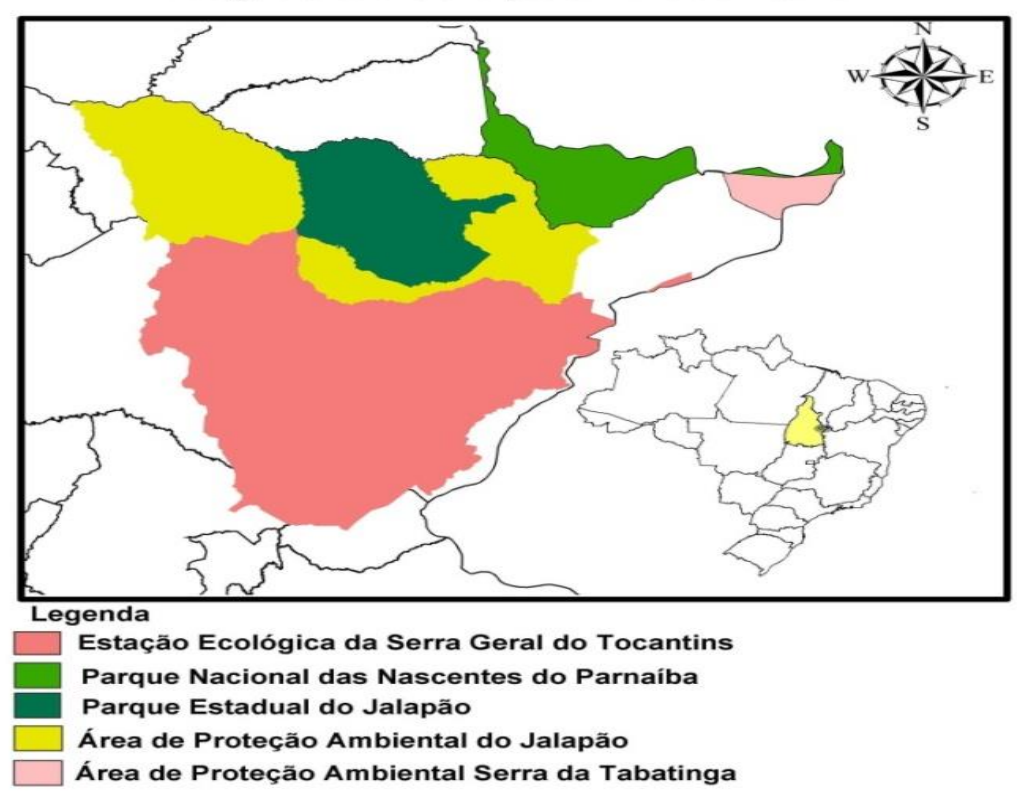

Fonte: SENNA, 2008

Figura 1.1 - UC do Jalapão 
É neste contexto que se buscou conhecer os impactos do ecoturismo na cidade de Mateiros, por entender a importância do PEJ para a cadeia produtiva do turismo no estado. Sabe-se também que sua relevância, independente da situação de sazonalidade turística, que é perceptível na região, deve ser estudada por várias áreas do conhecimento, dada a fragilidade ambiental local e o potencial turístico da região.

Mateiros é classificado como um destino de pequeno porte ao se considerar a definição de Pearce (2003) como sendo destinos turísticos urbano-periféricos com populações reduzidas, menor importância em sua função central e com tendência mais para receber do que para gerar turistas.

O Parque Estadual do Jalapão, criado pela Lei Estadual $n \cong 1.203$ de 12 de janeiro de 2001 e com área de 158.885,5 hectares, pertence à categoria de Unidade de Conservação de Proteção Integral. Seu principal objetivo é a preservação dos recursos naturais da região, fato este que limita as formas de exploração do local, permitindo apenas o aproveitamento indireto de seus benefícios. Restringindo-se apenas ao município de Mateiros, o acesso ao PEJ partindo de Palmas/TO é feito, principalmente, por dois caminhos, ao sul via Porto Nacional e Ponte Alta do Tocantins ou ao norte via Novo Acordo e São Félix (SEPLAN, 2003).

A região possui diversas sub-bacias que vão desembocar no Rio Tocantins, entre elas a Bacia do Rio Sono, que se contrasta com o aspecto árido do Cerrado. (SEPLAN, 2003). O resultado destes contrastes é uma imensidão semiárida recortada por águas límpidas, apresentando um forte potencial turístico, reconhecida pelo Ministério do Meio Ambiente (MMA) como ponto turístico do Brasil, incluído no Programa de Desenvolvimento do Ecoturismo da Amazônia Legal - PROECOTUR (SANTOS, 2007), como se podem citar os principais atrativos segundo dados da SEPLAN (2003):

- Cachoeira da Velha: possui formato de duas ferraduras com 15 metros de altura, suas águas permitem a prática de rafting.

- Dunas da Serra do Espírito Santo: com mais de 20 metros de altura, envolvidas por veredas, por Córrego das Areias e uma lagoa próxima; 
- Cachoeira do Formiga: suas águas cristalinas formam um poço para banho de aproximadamente 8 metros de diâmetro;

- Fervedouro: poço de águas ressurgentes hídricas que não permitem ao banhista afundar.

Como se pode perceber, a cidade foi escolhida para este estudo por ser a principal beneficiada com as práticas turísticas da região, por abrigar a maioria dos atrativos do Jalapão (FIG. 1.2).

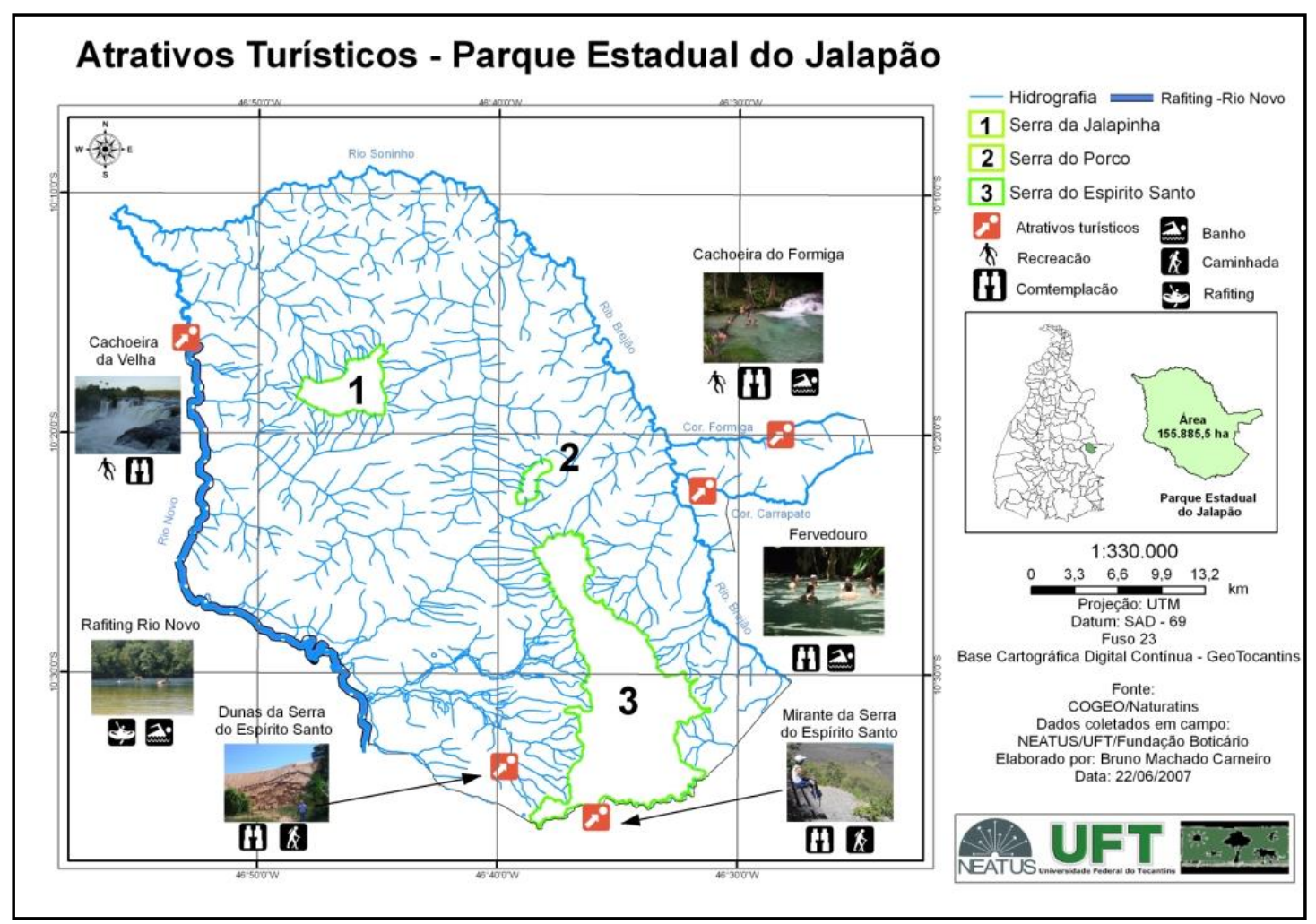

Fonte: SENNA, 2008

Figura 1.2 - Atrativos Turísticos - Parque Estadual do Jalapão.

De acordo com estudos de Dutra et al. (2007), que realizaram uma análise do perfil do turista que visita a região, mais da metade dos visitantes está entre a faixa de 15 e 45 anos (86\%), caracterizando um perfil jovem, mostrando ainda que grande parte tem uma renda alta e um alto nível de escolaridade, isto é, $41 \%$ dos visitantes disse receber acima dos $R \$ 4.000,00$ e $51 \%$ disseram que possuíam nível superior completo (51\%).

Através do método do Limite Aceitável de Câmbio (LAC), Ferreira (2007) analisou os impactos ambientais que vêm ocorrendo nos atrativos e 
acampamentos utilizados intensamente. Foram analisados aspectos biofísicos, como, por exemplo, quantidade de lixo, raízes expostas e árvores danificadas. Os principais impactos observados foram erosão do solo, abertura de vias de acesso aos atrativos, degradação da vegetação e lixo deixados nos atrativos. Foi então apresentado um estudo de capacidade de carga de cada atrativo local, onde foi possível mensurar a quantidade de pessoas que podem visitar o atrativo turístico simultaneamente. Apesar desses estudos de limitação de capacidade de carga, ao visitar a região percebe-se que muitas vezes estas limitações estabelecidas não estão sendo respeitadas, mesmo tendo sido explicitada para a cidade na época as necessidades para tal ação. Ainda há o agravante que a maioria dos atrativos naturais do local pertencem à proprietários particulares, logo, são vistos como uma forma de exploração turística por eles, dificultando as ações fiscalizatórias por parte dos órgãos ambientais.

Além disto, outra antiga discussão na região é se os acessos ao município de Mateiros devem ser asfaltados, criando a estrada parque, uma vez que hoje são estradas não asfaltadas que interligam o município à capital do estado e aos demais estados (DUTRA et al, 2008). Se por um lado teria como benefício de acesso inclusive no que tange aspectos de saúde, infraestrutura e outros, por outro lado, haveria também um incentivo ao turismo que poderia levar mais pessoas para uma região que não está totalmente preparada para receber um número maior de visitantes sem que haja estudos e controles ambientais.

Dada a fragilidade ambiental local e do crescimento do turismo na região, esse trabalho enfatizou a análise de indicadores socioambientais tais como, o Índice de Qualidade de Vida (IQV) para avaliar se o turismo trouxe benefícios para a comunidade local, a análise da tabela de Indicadores de Sustentabilidade da Organização das Nações Unidas (ONU) obtidas por meio de dados secundários, comparados com a Pegada Ecológica do Turismo (PET), para mensurar o impacto que o turismo deixou na região. Todos esses indicadores socioambientais foram avaliados quanto à sua aplicabilidade em destinos de pequeno porte, como é o caso de Mateiros/TO. 
A ideia para esta pesquisa surgiu como forma de continuidade da pesquisa realizada em 2007 por Santos et al., na comunidade quilombola chamada Mumbuca, pertencente ao município de Mateiros, bem como, propor a utilização de um instrumento de pesquisa que pudesse mensurar 0 antes e 0 depois do turismo. A principal conclusão do referido trabalho foi o IQV apurado de 0,390, que ainda representa baixo nível de desenvolvimento. Porém, houve um incremento do turismo na região com um aumento na ordem de aumento de $112,95 \%$ no índice. As narrativas orais demonstraram que os moradores estão satisfeitos com suas condições de vida e atribuem o ganho ao turismo e ao comércio do artesanato de capim dourado. Desta forma, percebeu-se que apesar dos baixos índices de qualidade de vida da região, a comunidade se mostra satisfeita com o que o turismo proporcionou para a comunidade. Ao analisar esses dados, surgiu então o desejo de conhecer se a realidade de Mateiros se assemelhava à comunidade de Mumbuca.

Um indicador é uma ferramenta que permite a obtenção de informações sobre uma dada realidade. Tem como principal característica o poder de sintetizar um conjunto complexo de informações retendo apenas o significado essencial dos aspectos analisados. É visto ainda como uma resposta sintomática às atividades exercidas pelo ser humano dentro de determinado sistema (MARZALL; ALMEIDA, 1999).

Dentro dos indicadores de desenvolvimento, destaca-se o Índice de Desenvolvimento Humano (IDH). Este índice tem sido utilizado desde 1993 pelo Programa de Desenvolvimento das Nações Unidas (PNUD) como importante ferramenta padronizada para medida do bem-estar de uma população. No entanto, é um indicador que apenas contempla variáveis da longevidade, educação e renda. Segundo Veiga (2005), o processo de desenvolvimento é muito mais amplo e mais complexo do que qualquer medida sumária conseguiria captar, mesmo quando completada com outros índices.

Outro possível indicador está relacionado à qualidade de vida. Segundo BAQUERO (2012), qualidade de vida geralmente envolve as condições materiais, condições primárias e fundamentais da vida humana, bem como as forças materiais de produção e transformações das condições materiais e a formação social. O IQV subsidia a análise do desenvolvimento. Lima (2003) 
observa que diversas abordagens têm sido utilizadas para conceituar e avaliar a qualidade de vida. Algumas centram na posse de bens materiais e outras, mais abrangentes, levam em consideração os aspectos materiais, culturais e sociais que influem na vida humana.

E é exatamente por entender que para analisar a qualidade de vida da população de Mateiros, necessitava-se analisar também os impactos advindos com a exploração da atividade turística na região, por intermédios de outros indicadores.

Sabe-se que o desenvolvimento da atividade turística, como qualquer outra atividade antrópica, provoca impactos negativos no meio ambiente, conforme destacam Feitosa e Gomez (2013): impacto estéticos e paisagísticos causados pela poluição arquitetônica; problemas com recolhimento, depósito e tratamento dos resíduos sólidos, poluição sonora e atmosférica, erosão dentre outros.

Para analisar esses impactos, pode se utilizar outro indicador que foi aplicado nessa pesquisa. Proposta por William Rees e Mathis Wackernagel (2002) a Pegada Ecológica (PE) ou Ecological Footprint (EF) que consistiu em sua metodologia original, em construir uma matriz de consumo de terra considerando algumas categorias principais de consumo humano, tais como: alimento, moradia, transporte, bens de consumo e serviços e as seis categorias principais do uso da terra, a saber, energia da terra, ambiente degradado construído, jardins, terra fértil, pasto e florestas sob controle. O principal objetivo deste índice é calcular a área de terra necessária para a produção e manutenção de bens e serviços consumidos por uma comunidade. Em 2002 foi realizada uma adaptação para sua utilização no turismo feita por Gössling et al. (2002) a partir do momento em que cria uma medida para determinar a quantidade de terras bioprodutivas, terras construídas e terras de energia fóssil necessárias para suportar a atividade turística.

Para efetivar essa análise, Gössling et al. (2002) estabeleceram quatro categorias de consumo, a saber: transportes, alojamento, atividades de lazer e por fim, alimentação e consumo de fibras, podendo possuir um ou mais tipos de terras associadas a cada categoria, conforme poderá ser verificado mais adiante no detalhamento da metodologia. 
Desta forma, também foi utilizada a Pegada Ecológica do Turismo para avaliar os impactos ambientais causados na região com a atividade turística de modo a perceber e comparar com a qualidade de vida da população de Mateiros para que fosse possível entender se o turismo estava gerando mais impactos positivos ou negativos na região estudada.

Nenhum estudo foi encontrado na literatura comparando os impactos do turismo utilizando os métodos da Pegada Ecológica do Turismo e do Índice de Qualidade de Vida de uma determinada população. Além disso, não se sabia ao certo se o turismo realmente trazia benefícios locais para se incentivar a implantação de um turismo sustentável para a região. Logo, caracterizou-se assim o aspecto de originalidade do presente estudo.

Como estratégia para o desenvolvimento sustentável, Campos (2005) relatou que vários autores caracterizam o ecoturismo como uma possibilidade de resposta ao modelo de desenvolvimento atual. $O$ autor destaca que conforme Molina (2001), essa nova concepção de turismo caracteriza-se pela valorização da conservação e aspectos educacionais da atividade turística, que, no entanto, da mesma forma que o turismo convencional, exige serviços básicos e um planejamento adequado às condições da realidade local. Segundo CAMPOS (2005) o ecoturismo exige planejamento e estudos de capacidade de suporte, infraestrutura adequada e não impactantes e normas que regulamentem a atividade.

O ecoturismo é descrito como o tipo de turismo adequado em habitats naturais que enfatiza o cuidado para não alterar a integridade do ecossistema, ao mesmo tempo em que produz benefícios econômicos para a população local (GOELDNER, RITCHIE, MCINTOSH, 2002). Nesse sentido se apresenta como uma ferramenta de desenvolvimento sustentável que oferece práticas operacionais de vivência do indivíduo ou de um grupo que afetam suas atitudes e valores em relação ao equilíbrio, conservação e uso do meio ambiente, bem como no reconhecimento dos impactos da atividade de exploração turística na estética e cultura existente.

Levando estas problemáticas em conta, buscou-se, por meio deste trabalho, a ampliação do estudo realizado por Santos et al. (2007) para a região de Mateiros, utilizando o Índice de Qualidade de Vida da população 
local, comparando com a Pegada Ecológica do Turismo na região, buscando avaliar se o turismo deve ou não ser investido na região estudada.

Dessa forma, será apresentado no capítulo dois os objetivos gerais e específicos desse trabalho. No capítulo três será apresentado um levantamento bibliográfico apresentando temáticas sobre o desenvolvimento sustentável, as dimensões da sustentabilidade, o turismo sustentável que apresentará os principais impactos positivos e negativos que a atividade turística pode ocasionar e no final do capítulo será apresentando a conceituação dos principais autores da literatura sobre os indicadores utilizados nesse trabalho, a saber: os indicadores das Organizações das Nações Unidas, o índice de qualidade de vida e a pegada ecológica do turismo.

No capítulo quatro se apresentará os procedimentos metodológicos que descreverão a amostra, os instrumentos de coleta de dados, a descrição também da região estudada e como foi feita a interpretação dos dados.

O capítulo cinco trará os resultados e discussões desse trabalho, iniciando pela análise dos indicadores da Organização das Nações Unidas, seguida pela análise dos resultados do índice de qualidade de vida que foi subdividida pelos principais indicadores, tais como: perfil do entrevistado, condições de moradia, aspectos sanitários, aquisição de bens de consumo duráveis, a comunicação e lazer da comunidade, saúde, educação, emprego e renda e meio ambiente. Após a apresentação deu-se a consolidação dos dados do índice de qualidade de vida e a finalização da análise desse indicador com a análise comparativa entre algumas variáveis do IQV. Para finalizar o capítulo foi apresentado o cálculo da pegada ecológica do turismo na região de Mateiros também subdividida por categoria de transporte com as terras construídas e terras de energia fóssil, as categorias de resíduos sólidos, água, alojamento, atividades de lazer e alimentação e consumo de fibras, sendo finalizado o capítulo com a apresentação do cálculo final da pegada ecológica do turismo da cidade de Mateiros. Finalizando o trabalho com a apresentação das principais conclusões do trabalho no capítulo seis. 


\section{2 - OBJETIVOS}

\section{1 - Objetivo Geral}

Este trabalho pretende, por meio de uma visão sistêmica, levantar, discutir e avaliar as perspectivas de sustentabilidade socioambiental no contexto do desenvolvimento do turismo do município de Mateiros/Tocantins, avaliando a aplicabilidade de indicadores socioambientais em destinos de pequeno porte.

\section{2 - Objetivos Específicos}

Construir, a partir de dados primários e secundários, o Índice de Qualidade de Vida da cidade Mateiros/TO;

$\checkmark$ Compatibilizar os índices aferidos com os indicadores de sustentabilidade das Nações Unidas;

$\checkmark$ Verificar a Pegada Ecológica do Turismo na cidade de Mateiros analisando os impactos do turismo na região;

$\checkmark$ Comparar os resultados do índice de qualidade de vida com a pegada ecológica do turismo, analisando se a atividade turística deve ou não ser incentivada na região;

$\checkmark$ Analisar a aplicabilidade dos indicadores de sustentabilidade das Nações Unidas, o índice de Qualidade de Vida e a Pegada Ecológica do Turismo para destinos de pequeno porte. 


\section{3 - REVISÃO DE LITERATURA}

\section{1 - O Desenvolvimento sustentável}

A busca pelo desenvolvimento sustentável permeia diversas esferas que vão desde o campo político, social, econômico, empresarial e pessoal. Mas, afinal, o que seria o desenvolvimento sustentável?

O conceito de desenvolvimento sustentável mais utilizado e disseminado nos estudos científicos é o anunciado por Brundtland em 1987 no relatório Our Common Future que foi publicado na World Commission on Environment and Development (WCED) em que conceitua desenvolvimento sustentável como processo que permite satisfazer as necessidades da população atual sem comprometer a capacidade de atender às gerações futuras (MUNCK E BORINDE-SOUZA, 2013).

A evolução da construção desse conceito pode ser visto em linhas gerais nos eventos que tomaram conta das décadas de 70 a 90 , segundo Beni (2003):

- 1972 - Conferência da ONU sobre Meio Ambiente Humano em Estocolmo: Examina-se a questão de maneira global e ordenada na busca de soluções aos problemas existentes buscando definir linhas de ação para a problemática ambiental;

- 1974 - Ignacy Sachs e sua equipe interdisciplinar, sediada no Cired Centre International de Recherche sur l'Environnment et le Dévéloppement, ampliam e diversificando os horizontes da questão do eco desenvolvimento, criada em Estocolmo em 1972;

- 1974/1975 - Com a Declaração de Cocoyoc de 1974, e o Relatório Que Paire apresentado no final de 1975 pela Fundação Dag Hammarskjold, por ocasião da $7^{a}$ Conferência Extraordinária das Nações Unidas, reutilizaram as ideias de Sachs e sua equipe, fazendo uso das as 
expressões "um outro desenvolvimento" e "desenvolvimento sustentado", sem utilizar o termo "eco desenvolvimento" de forma explícita;

- 1982 - Em Nairóbi, Quênia, sede do Programa das Nações Unidas para o Meio Ambiente (PNUMA) realizou-se reunião comemorativa do $10^{\circ}$ aniversário da Conferência de Estocolmo, avaliando os resultados até então obtidos e a um exame da mudança de percepção da problemática ambiental;

- 1983 - Em resposta a uma decisão da Assembleia Geral da ONU, foi estabelecida a Comissão Mundial sobre Meio Ambiente e Desenvolvimento, presidida pela norueguesa Gro Brundtland. Com o objetivo de reexaminar a questão ambiental, inter-relacionando-a com a questão do desenvolvimento, e propor programas de ação. Quatro anos depois elaborou-se o relatório final da comissão, intitulado "Nosso Futuro Comum", conhecido também como Relatório Brundtland. Desse relatório surge a expressão "desenvolvimento sustentável", com intenção de despertar a conscientização pública e evidenciar a necessidade de um melhor gerenciamento do meio ambiente para sustentar o planeta Terra; e

- 1992 - Muitas das ideias e percepções do Relatório Brundtland foram discutidas na Rio-92. Entre as principais destacam-se: a Carta da Terra, uma declaração de princípios básicos a serem seguidos por todos os povos com respeito ao meio ambiente e ao desenvolvimento; e a Agenda 21, um plano de ação com as metas aceitas universalmente para o período pós - 1992 e entrando pelo século XXI.

A Eco-92 inicia um processo mais concreto ao delimitar um programa de desenvolvimento sustentável, a Agenda 21. Ela pode ser definida com um instrumento de planejamento para a construção de uma sociedade mais sustentável, que pode em qualquer base geográfica, seja internacional, nacional ou local. Ela concilia métodos de proteção ambiental, justiça social e eficiência econômica (ONU, 1992). 
Drummond (1998) traz uma leitura de Paul Claval em que categoricamente afirma que é um utopismo o desenvolvimento sustentável, pois para ele o desenvolvimento sempre envolve uma maior pressão sobre os recursos naturais por conduzir a padrões de consumo mais elevados.

O que a ciência pode fazer pelo desenvolvimento sustentável? A Secretaria Geral da Eco-92 solicitou ao Conselho Internacional de Uniões Científicas (ICSU) que fosse criado um órgão de aconselhamento científico, para colaborar com discussões governamentais que permeavam o encontro. Em novembro de 1991, um grupo de cientistas reuniu-se em Viena para discutir as questões que seriam trazidas para a Conferência no Rio em 1992. Seu principal objetivo foi examinar como a ciência poderia entrar em contato com os emergentes problemas ambientais (MENON, 1994). O mesmo autor afirma que o papel da ciência é observar, monitorar e analisar as mudanças globais ocorridas e mantendo a sociedade informada.

Pereira e Beltrão (2007) afirmam que a informação e o conhecimento são as principais fontes de riqueza. Eles também trazem a leitura de Prusak (1994) que destaca que na sociedade da informação, o sucesso é determinado pelo saber e não somente pelo que se possui.

Sabe-se que não adiantaria apenas a disseminação do conhecimento. Deve-se utilizar adequadamente os meios de comunicação disponíveis, decodificando a linguagem academicista de forma a construir um diálogo com os saberes e com a cultura local (PEREIRA e BELTRÃO, 2007). Os autores destacam ainda a importância da formalização de redes interinstitucionais para o planejamento, produção, aplicação, avaliação de estratégias e políticas públicas para o desenvolvimento sustentável.

Vale lembrar que o que é sustentável em uma localidade, pode não ser em outras. Por isso, muitos municípios aderiram a construção coletiva da Agenda 21 levando em consideração a suas realidades. Mas ainda pouca efetividade se percebe de fato, pois a problemática ambiental está diretamente ligada ao desenvolvimento, mas esse na maioria das vezes é definido pelo crescimento econômico de um país ou região. Dessa forma, tem-se uma dualidade nesse conceito. 
Segundo Aquino et al. (2015) a construção de indicadores de desenvolvimento sustentável no Brasil integra-se ao conjunto de esforços internacionais no que diz respeito aos pressupostos trazidos pela Conferência das Nações Unidas sobre o Meio Ambiente e Desenvolvimento, a Eco-92, sobre meio ambiente, desenvolvimento e informações para a tomada de decisões. Em 2008, segundo os autores, foi feita a publicação "Os Indicadores de Desenvolvimento Sustentável: Brasil 2008", onde dá continuidade à serie iniciada em 2002, categorizando as dimensões da sustentabilidade, como se verá a seguir.

\section{2 - Dimensões da sustentabilidade}

Sachs em 2000 apontou que o desenvolvimento sustentável deve ser implementado por uma metodologia de planejamento, como sendo um espaço de aprendizado social, equidistante e materializando-se sobre uma síntese pedagógica (BENI, 2003). E é nesse sentido que o autor afirma que o planejamento participativo recupera a participação social da sociedade, fazendo com que o cidadão contribua na elaboração das eco-estratégias desde a informação até a execução da ação proposta, transformando a sociedade civil em um terceiro sistema.

O autor categoriza algumas dimensões de sustentabilidade para auxiliar na elaboração das eco-estratégias do desenvolvimento, a saber:

1 - Sustentabilidade Social: baseia-se no ser e que seja sustentado por uma maior equidade na distribuição do ter, nos direitos e nas condições das amplas massas da população, e achatamento da distância entre os padrões de vida dos mais ricos e mais pobres.

2 - Sustentabilidade Econômica: possibilita uma melhor alocação e gestão mais eficiente dos recursos e por um fluxo regular do investimento público e privado.

3 - Sustentabilidade Ecológica: Sachs em 2000 traz nessa dimensão a ideia de incrementar o aumento da capacidade de recursos naturais, limitando os recursos não-renováveis ou ambientalmente prejudiciais, reduzindo o volume de poluição, autolimitando o consumo material pelas 
camadas sociais mais privilegiadas, intensificando a pesquisa de tecnologias limpas e definindo regras para uma adequada proteção ambiental.

4 - Sustentabilidade Espacial: volta-se a uma configuração rural-urbana mais equilibrada com ênfase nas questões de concentração excessiva nas áreas urbanas, processos de colonização descontrolados, promoção de projetos modernos de agricultura regenerativa e agroflorestamento, industrialização centralizada, criação de empregos rurais não-agrícolas, e o estabelecimento de uma rede de reservas naturais e de biosfera para proteger a biodiversidade.

5 - Sustentabilidade Cultural: Prioriza-se o respeito das tradições culturais, e até mesmo a pluralidade das soluções particulares

6 - Sustentabilidade Política: privilegia a negociação da diversidade de interesses envolvidos em questões fundamentais desde o âmbito local ao global.

Ainda nas dimensões da sustentabilidade, Aquino et al. (2015) afirmam que a escolha dos indicadores de desenvolvimento pode, por meio de produção regular de estatísticas sobre os temas abordados, refletir as situações e especificidades de cada país, permitindo ainda comparações entre países e regiões, indicando necessidades e prioridades para a formulação, monitoramento e avaliação de políticas ambientais.

E para auxiliar a análise dos indicadores são aplicadas as dimensões que envolvem a sustentabilidade (AQUINO et al., 2014), dimensões essas que foram os parâmetros de análises para o presente trabalho:

- Dimensão ambiental: o capital natural é incluso no sistema capitalista. Dessa forma, busca-se incessantemente a melhoria da qualidade ambiental pela sociedade para que as novas gerações possam usufrui-las de forma satisfatória;

- Dimensão institucional: a orientação política é referenciada para que as mudanças sejam implementadas na sociedade em 
forma de ciência, tecnologia de processo e produtos, bem como, a forma atuante do poder público quanto à fiscalização e proteção do meio ambiente;

- $\quad$ Dimensão social: a qualidade de vida e a justiça social devem prevalecer, respeitando a satisfação das necessidades humanas. A busca aqui, refere-se à redução das desigualdades sociais com criação de postos de trabalho que deem condição de sobrevivência humana dentro dos padrões mínimos de atendimento às necessidades básicas.

- Dimensão econômica: o desempenho econômico pode influenciar os aspectos de sustentabilidade, buscando uma mudança gradativa em busca de uma almejada sustentabilidade.

Cunha e Cunha (2005) afirmam que para que haja o desenvolvimento local com base no turismo sustentável é necessário o envolvimento de relações bastante complexas e só poderá ser concretizado se forem levadas em conta as diversas dimensões de uma dada região ou território.

\section{3 - Turismo Sustentável}

Assim como o desenvolvimento sustentável, também é necessário que haja a compreensão do conceito de turismo sustentável. Segundo a Organização Mundial do Turismo (OMT), turismo sustentável seria aquele capaz de diminuir as assimetrias regionais existentes entre os países e no interior dos países, na medida em que esse vai ao encontro das necessidades das regiões turísticas por proteger e aumentar as oportunidades de desenvolvimento nas regiões. Mas as diretrizes para o desenvolvimento do turismo devem ser aplicadas em todas as formas de turismo (OLIVEIRA E MANSO, 2010):

- Otimizar o uso dos recursos ambientais, mantendo-se os processos ecológicos essenciais; 
- Ajudar na conversação dos recursos naturais e da biodiversidade local;

- Respeitar a autenticidade sociocultural das comunidades receptoras, conservando suas culturas arquitetônicas e seus valores tradicionais; e

- Assegurar atividades viáveis em longo prazo que reportem benefícios socioeconômicos a todos os agentes.

De acordo com Weaver (2005) turismo sustentável envolve basicamente minimizar os impactos negativos e maximizar os impactos positivos. $O$ autor afirma que os debates do turismo sustentável se iniciaram após a Agenda 21, quando a "UN Commission on Sustainable Development" implementou o "Tourism Programme" para facilitar a implementação da Agenda 21 no setor de turismo.

Beni (2003) destacou que em abril de 1995, por iniciativa da ONU, realizou-se a Primeira Conferência sobre Turismo Sustentável, em Lanzarote, nas Ilhas Canárias. Foi copatrocinada pelo Programa Ambiental dessa mesma organização, e pelo Programa sobre o Homem e a Biosfera da Organização das Nações Unidas para a Educação, a Ciência e a Cultura (Unesco) e pela OMT. Teve como uma das principais preocupações a observação que expressou a maioria dos participantes, de que a iniciativa privada, da época, pouco se sensibilizava com os programas e as ações de preservação ambiental. O autor ainda destaca que de Estocolmo até a Rio-92 foi evidente a polarização desenvolvimentista, formada pela riqueza dos países desenvolvidos ou industrializados do Norte e pela pobreza dos países em desenvolvimento ou do terceiro mundo do Sul.

Insere-se nesse evento os conceitos como certificação ambiental, atuação responsável e gestão ambiental, buscando assim mudar a postura reativa na relação entre empresas e órgãos governamentais, de ordenamento, normalização, legislação e fiscalização e as instituições ambientais, notadamente as Organizações não-governamentais (ONG). 
Beni (2003) ainda destaca que nesse mesmo ano, entra em vigor as normas britânicas (British Standard - BS 7750) Especification for Environmental Management Systems que serviriam de base para a elaboração de um sistema de normas ambientais em âmbito mundial.

\begin{abstract}
A entrada em vigor dessas normas internacionais de gestão ambiental, denominadas de série ISO-14000 e sua já anunciada integração futura com as normas de gestão de qualidade (ISO9000), constituíram o coroamento de uma longa caminhada em direção da conservação do meio ambiente e do desenvolvimento em base sustentável (BENI, 2003).
\end{abstract}

Weaver (2005) traz uma importante análise sobre turismo sustentável. O termo turismo sustentável incentiva a perpetuação de um insustentável statu quo. Para o autor, o termo "sustentabilidade" em si tem conotações de estado estacionário que sugerem a manutenção da situação existente. Ele utiliza o exemplo: uma área de deserto ou ambiente rural bucólico. Se o ambiente natural e sociocultural de um destino não seja indevidamente estressado, então este não é problemático e uma abordagem de statu quo de sustentabilidade se justifica, isto é, manter-se como está. No entanto, se esses ambientes são degradados, como no caso de cidades do interior arruinadas, praias poluídas ou pastagens infestadas com plantas exóticas, a abordagem do turismo sustentável é necessária para corrigir um statu quo insustentável.

Segundo Rodrigues et al. (2014) o desenvolvimento turístico sustentável exige uma abordagem multidisciplinar dada a transversalidade do setor. Os autores ainda afirmam que atuar no setor pressupõe projetos e estratégias de desenvolvimento que englobem as diferenças entre as dimensões econômicas, sociais e culturais, não esquecendo o envolvimento dos residentes locais.

Beni (2003) traz uma análise sobre as pesquisas de instituições internacionais de defesa, preservação ecológica e certificação ecológica, como a World Wildlife Foundation, Forest Stewardship, Rainforest Alliance, a International Ecoturism Society, a CST - Certificacion para la Sostenibilidad Turística, dentre outros. Para o autor, todas essas organizações trabalhavam e ainda trabalham com metodologia e parâmetro de qualidade, preservação e 
sustentabilidade ambiental. A maioria não se preocupa em aprofundar os estudos e pesquisas econômicas e político-sociais, resistindo à ideia de trazer o turismo para a ocupação de espaços naturais e de áreas protegidas, limitando-se a estudar os impactos nesses locais.

\subsection{1 - Impactos Negativos do e no turismo}

O turismo é hoje uma importante ferramenta de desenvolvimento econômico, social e cultural de uma dada região. Mas ao mesmo tempo é uma indústria muito complexa que envolve inúmeros intervenientes. Dessa forma, ele pode ter um papel positivo em todos os aspectos já levantados, mas ao mesmo tempo pode levar a impactos negativos que em muitos lugares tornamse irreversíveis.

Segundo a United Nations Environment Programme - UNEP (2015), os impactos negativos do turismo ocorrem quando o nível de utilização do visitante é maior do que a capacidade do meio ambiente para lidar com este uso dentro dos limites aceitáveis de mudança. O uso irracional dessa indústria pode representar uma ameaça para muitas áreas naturais em todo o mundo, conduzindo a impactos como erosão do solo, o aumento da extinção de espécies ameaçadas e a vulnerabilidade do meio frente aos constantes incêndios florestais.

O programa subdivide as principais ameaças para o desenvolvimento de um turismo sustentável nas regiões: impactos econômicos, socioculturais e ambientais. A seguir serão descritas as formas de impactos do turismo.

\subsubsection{1 - Impactos econômicos negativos do turismo.}

Segundo a UNEP (2015) a indústria do turismo gera benefícios econômicos substanciais tanto para os países receptores quanto para os países de origem dos turistas. Tal como acontece em outras formas de 
impacto, o desenvolvimento econômico traz consequências positivas e negativas.

De acordo com dados do Ministério do Turismo (MTUR, 2014) o turismo é responsável por $9 \%$ do Produto Interno Bruto (PIB), sendo que 1 em cada 11 empregos no mundo são vinculados ao turismo. Além disso, os embarques internos passaram de 28 milhões em 2000 para 89 milhões em 2013.

Sabe-se também que nem sempre esses números são revertidos para aspectos economicamente positivos.

A UNEP destaca que há muitos custos ocultos para o turismo que geram efeitos econômicos desfavoráveis sobre a comunidade de acolhimento. Para a organização, os países desenvolvidos conseguem obter mais lucros com o turismo do que os países em desenvolvimento, isso porque os países menos desenvolvidos tem a necessidade mais urgente para a renda, emprego e aumento geral do nível de vida por meio do turismo. Eles afirmam ainda que a razão para isso também se deve a transferência, em grande escala, de receitas do turismo fora do país de acolhimento e exclusão de empresas e produtos locais.

A UNEP denomina como "leakage" (que em uma tradução literal equivaleria a "fuga") os valores subtraídos do valor total gasto pelo turista após pagamento de pessoal, impostos, dentre outros. $\mathrm{Na}$ maioria dos pacotes turísticos com tudo incluído, os valores vão para companhias aéreas, hotéis e outras, muitas vezes internacionais, e não nas empresas locais. Segundo a organização, de cada U $\$ 100$ gastos em um passeio turístico por um turista de um país desenvolvido, apenas cerca de $U \$ 5$, na verdade, permanece na economia do destino dos países em desenvolvimento.

Essas "fugas" podem ocorrer de duas formas: com a fuga de importação, isto é, quando o país receptor não possui os padrões exigidos pela demanda turística estrangeira, como é o caso de bebidas e alimentos. Os países muitas vezes não têm uma indústria fornecedora e grande parte da renda como turismo, deixa o país para pagar por essas importações. A outra forma de acontecer essa "fuga" se dá com a exportação. As corporações multinacionais 
e grandes empresas estrangeiras contribuem substancialmente para essa fuga de exportações. Muitas vezes em destinos menos desenvolvidos, eles são os únicos que possuem capital necessário para investir na construção de infraestrutura e equipamentos turísticos. Logo, essas grandes corporações financiam a construção de grandes estruturas e depois acabam retirando os lucros para seus países de origem.

A ONU citado por UNEP (2015) constatou "fugas" significativas associadas com o turismo. O relatório da ONU avaliou a contribuição do turismo para a renda nacional, os níveis brutos de rendimentos ou cambial bruto, e descobriu que o lucro líquido do turismo, após as deduções que foram feitas para as despesas de câmbio necessárias, eram muito significativos para a indústria. Este relatório constatou "fugas" associadas com: (a) as importações de materiais e equipamento para construção; (b) as importações de bens de consumo, especialmente alimentos e bebidas; (c) repatriação de lucros auferidos por investidores estrangeiros; (d) gastos promocionais no exterior e (e) amortização da dívida externa contraída no desenvolvimento de hotéis e resorts.

Outro destaque dado aos impactos econômicos negativos foram as empresas que oferecem "tudo incluído" em seus pacotes. Eles exemplificam a permanencia de turistas durante todo um dia em navio de cruzeiro ou resorts, não sobra espaço para que a população local possa lucrar com o turismo.

Outro aspecto a ser considerado aqui são os custos de infraestrutura turística necessária para que a atividade se desenvolva. Em muitos casos, as grandes empresas turísticas podem exigir que o governo local melhore as condições aeroportuárias, estradas e outras infraestruturas básicas para o turismo, além de em alguns casos exigir incentivos fiscais e outras vantagens financeiras que são onerosas para o governo. Isso muitas vezes acaba comprometendo investimentos em outras áreas sociais como saúde e educação que certamente sofrerão impactos.

UNEP (2015) ainda destaca que quando ocorre uma procura crescente de serviços básicos e bens por parte dos turistas, muitas vezes, isto pode causar aumento de preços que afetam diretamente os moradores da 
localidade, cuja renda não cresce proporcionalmente. Além disso, como desenvolvimento do turismo, o aumento na demanda imobiliária também pode ocorrer, ocasionando o mesmo com os valores da terra e custos de construção. Isso agrava ainda mais quando investidores de fora se tornam dominantes, aumentando assim a especulação imobiliária.

Além disso, a dependência econômica da comunidade local sobre o turismo pode levar a sérios problemas. Muitos países abraçam o turismo como uma maneira de impulsionar a economia, mas uma recessão econômica e os impactos de desastres naturais ou alterações dos padrões de turismo podem ter um efeito perigoso sobre o setor do turismo local. Hoje em dia, o terrorismo pode esvaziar uma temporada turística com graves consequências socioeconômicas.

Um reflexo da dependência do turismo também pode refletir nos postos de trabalho, isso porque a indústria do turismo tem um caráter sazonal. Logo, a insegurança de não se saber se estarão empregados no fim da estação, dificuldades para obtenção de treinamento, benefícios médicos relacionados com o emprego, dentre outros aspectos. Além disso, as crises econômicas podem ser devastadoras para os fluxos de turismo receptivo.

\subsubsection{2 - Impactos socioculturais negativos do turismo:}

O principal impacto sociocultural ligado ao turismo é a perda de identidade e dos valores locais por influências que podem estar relacionadas a aspectos tais como:

- Mercantilização da cultura local na medida em que os rituais são modificados para atender a expectativa daqueles que visitam a localidade;

- Padronização dos serviços turísticos para atender as demandas dos visitantes, isto é, iniciam-se a chegada de conhecidos restaurantes de fast-food e cadeias hoteleiras em detrimento à alimentação local e hospedagem domiciliares;

- Perda de autenticidade ou autencidade encenada na medida em que há adaptações das manifestações culturais com o gosto dos 
turistas ou ainda fazendo apresentações culturais como se fossem parte do cotidiano e na verdade constituem uma autencidade encenada;

- Adaptação às demandas turísticas, como por exemplo, as lembranças, artes, artesanato e manifestações culturais que fogem de sua proposta original para adaptar ao mercado de compras e vendas. Ao mesmo tempo em que isso contribui para a autoestima dos artesãos por terem seus produtos melhor aceitos pelos turistas e a fuga cultural pode ocorrer também; e

- Poluição estética, pois muitas vezes há um choque entre construções históricas locais dando lugar a prédios ou construções modernas que não condizem com o espírito tradicional ou característico local.

Todos esses fatores podem ocorrer devido a choques culturais como resultado do encontro de diferentes culturas, grupos étnicos e religiosos, valores e estilos de vida, línguas e níveis de prosperidade. Isso pode gerar tanto estágios de euforia, quanto de repulsa por não aceitarem intervenções em suas culturas. As diferenças nos padrões de consumo e estilos de vida podem acarretar também um comportamento de cópia com o modelo que lhes parece mais adequado.

Além disso, é comum ocorrer irritação devido ao comportamento de algum turista que deixaram de respeitar os costumes locais e valores morais. Por exemplo, em países muçulmanos há alguns conflitos entre povos por aqueles possuirem padrões rígidos com relação à aparência e comportamento das mulheres muçulmanas.

Outrossim, ainda há os conflitos de uso de recurso, como a concorrência entre o turismo e as populações locais. A comunidade ainda pode arcar com investimentos locais, como por exemplo, o aumento de imposto para investimentos em abastecimento de água ou instalações sanitárias.

Ainda há a deterioração cultural que ocorre por vandalismo, desordem, furtos e remoção ilegal de itens do patrimônio cultural. Normalmente ocorre 
quando os locais históricos estão desprotegidos ou ainda quando o ambiente construído tradicional é substituído ou praticamente desaparece.

Outro ponto a ser analisado são os conflitos com usos da terra tradicionais. Os conflitos surgem quando a escolha tem que ser feita entre 0 desenvolvimento da terra para instalações turísticas ou de infraestrutura e uso da terra tradicional local.

Ainda podem existir problemas mais graves como aumento nos índices de criminalidade local, prostituição e turismo sexual nas cidades turísticas. Além disso, ainda estudos da OIT (UNEP, 2015) mostram que muitos postos de trabalho deixam muito a desejar, como: longas horas de trabalho, emprego instável, baixa remuneração, pouca formação e poucas chances de qualificação ou pior, que seria a exploração de mão de obra infantil.

\subsubsection{3 - Impactos ambientais negativos do turismo.}

O UNEP (2015) destaca alguns dos impactos negativos que podem surgir ou se evidenciar com o advento do turismo em algumas regiões:

- Perda da diversidade biológica: o programa destaca as principais ameaças, caso ocorra, que são: o comprometimento do abastecimento de comida, oportunidades de lazer e turismo e desmatamentos e deficiência no fornecimento de energia. Isso pode interferir no equilíbrio de espécies, ou ainda, desestabilizar os ecossistemas e enfraquecer sua capacidade de lidar com desastres naturais, como inundações, secas e furacões e as alterações climáticas. Essa perda pode indicar a perda do potencial turístico de uma dada região;

- Os turistas, mesmo que inconscientemente, podem levar espécies que não são nativas para o ambiente local em que vivem. $E$ isso pode acarretar enormes perturbações e mesmo destruição de ecossistemas;

- A indústria do turismo pode contribuir para a destruição da camada de ozônio com a construção de novos empreendimentos e suas operações diárias com geladeiras, ar condicionado (apesar de tais eletrodomésticos 
terem uma preocupação maior com a minimização dos impactos ambientais), e principalmente a utilização de aviões nas viagens, também contribuem significativamente para a emissão de dióxido de carbono $\left(\mathrm{CO}_{2}\right)$ uma vez que podem contribuir para as mudanças climáticas ao emitirem gases que contribuem para emissão de gases de efeito estufa;

- Recursos aquáticos: A indústria do turismo em geral utiliza excessivamente recursos hídricos para hotéis, piscinas, campos de golfe e uso pessoal da água pelos turistas. Isso pode resultar em escassez de água e degradação dos recursos hídricos, bem como a geração de um maior volume de águas residuais. Por causa do clima quente em algumas regiões, há uma tendência dos turistas consumirem mais água quando estão em férias do que em casa. Outro ponto de destaque do Programa é quanto à manutenção de campos de golfe que podem levar a um esgotamento dos recursos de água doce, por exemplo, se forem desenvolvidos desordenadamente;

- Os recursos locais: o turismo pode criar uma grande pressão sobre os recursos locais, como energia, alimentos e outras matérias-primas que podem já estar em falta. Devido ao carácter sazonal da indústria, muitos destinos têm dez vezes mais habitantes na época de alta como na de baixa temporada. A alta demanda é colocada sobre estes recursos para atender as altas expectativas que os turistas têm muitas vezes (aquecimento adequado, água quente, etc.);

- A degradação da terra: recursos terrestres importantes incluem minerais, combustíveis fósseis, solos férteis, florestas, zonas úmidas e da vida selvagem. $O$ aumento das construções para atender ao turismo e o lazer aumentou a pressão sobre esses recursos e em paisagens cênicas. $O$ programa destaca o impacto direto sobre os recursos naturais que podem vir com o turismo e com a provisão de infraestruturas turísticas. Além disso, as florestas podem sofrer impactos negativos do turismo na forma de desmatamento causado pela coleta de lenha e limpeza de terrenos;

- O turismo pode causar as mesmas formas de poluição como qualquer outra indústria: as emissões de $\mathrm{CO}_{2}$, ruído, resíduos sólidos e lixo, 
lançamentos de esgoto, óleo e produtos químicos, até mesmo a poluição arquitetônica / visual;

- A poluição atmosférica e sonora: os transportes aéreos, rodoviários, ferroviários estão aumentando consideravelmente e uma das consequências disso é que segundo UNEP (2015) um estudo estima que atualmente mais de $60 \%$ das viagens aéreas são realizadas a passeio ou para fazer turismo. Além da poluição atmosférica relatada acima ainda há a poluição sonora que inclui também outros meios de transporte utilizados em turismo, como motos de neve, jet skis, carros e ônibus, que além de causar estresse pode levar até à perda da audição em seres humanos, animais silvestres, dentre outros;

- Resíduos sólidos e lixos produzidos pela atividade turística: a eliminação de resíduos é um problema sério; o descarte inadequado pode ser um grande problema no ambiente natural - rios, áreas cênicas e estradas. Resíduos sólidos e lixos podem degradar os aspectos física da água, da orla costeira e causar a morte de animais aquáticos;

- A construção de hotéis, recreações e outras instalações turísticas muitas vezes levam a um aumento da poluição com esgotos. E a poluição por esgotos sendo descartados desordenadamente podem ameaçar a saúde dos seres humanos e animais;

- Locais de paisagens atraentes, como praias, lagos, ribeiras e topos de montanhas e encostas são zonas de transição que se caracterizam por possuir um ecossistema rico em espécies, mas ao mesmo tempo se tornam ambientalmente frágeis. Esses mesmos lugares são ambientes que costumam atrair visitantes em busca de conhecer tais paisagens. A utilização desordenada desse ambiente pode causar sérios problemas ambientais que nem sempre serão percebidas em curto prazo;

- A construção de alojamentos frequentemente requer o desmatamento de florestas e áreas antes arborizadas. Essas atividades podem causar perturbações graves e erosões no ecossistema local;

- Ainda que haja trilhas construídas em locais turísticos, alguns turistas não conscientizados, eventualmente, desviam dessas trilhas estabelecidas em busca de aventura. E esse pisoteio pode causar danos ainda mais extensos ao meio ambiente; 
- Em áreas marinhas muitas atividades turísticas ocorrem em ecossistemas frágeis, dentre elas: ancoragem, mergulho, pesca desportiva, iatismo dentre outros; $\mathrm{e}$

- Algumas atividades turísticas também podem causar estresse para animais e alterar o seu comportamente natural, tais como a observação da vida selvagem, quando turistas vêm perto demais ou produzem barulho e agitação, podendo provocar pressão sobre hábitos e comportamentos animais.

\subsubsection{4 - Impactos Ambientais Globais que podem afetar o Turismo}

Para que aconteça o turismo depende primordialmente de paisagens naturais ou construidas. Mas a atividade pode não só causar impactos negativos como foi visto anteriormente, como também ser impactado por desastres naturais que acontecem nessas regiões turísticas.

Catástrofes como enchetes, terremotos, incêndios, vulcões, avalanches, secas ou doenças podem ter um grave efeito no turismo receptivo de algumas localidades. Cita-se aqui a tragédia ocorrida em dezembro de 2004 na Tailândia quando um tsunami atingiu a costa asiática matando mais de 200 mil pessoas entre habitantes e turistas.

O turismo não só contribui para as mudanças climáticas, como também é afetado por ele. Essas alterações climáticas podem aumentar a gravidade e frequência das tempestades e eventos climáticos extremos, além de provocar secas, doenças e ondas de calor.

O aquecimento global pode resultar em efeitos como os acima descritos e por consequência impactar o turismo na medida em que, por exemplo, se terá menos neves em estações de esquis ou o oposto como o excesso de calor, pode afastar turistas de regiões com medo de doenças ou escassez de água. Ou ainda o aumento do nível do mar, resultado do derretimento de geleiras e calotas polares, pode ameaçar áreas costeiras e marinhas com inundações generalizadas em países de baixa altitude (ELSASSER; BÜRKI, 2002). 
Além disso, ainda pode ocorrer o aumento de eventos de condições meteorológicas extremas, tais como tornados, furacões e tufões. Danos provocados pelo vento, ondas de tempestades, fortes chuvas e inundações causam grandes perdas para o local turístico. Outro exemplo que impacta 0 turismo é a grande queimada que dependendo de sua gravidade pode levar ao fechamento temporário de parques ecológicos (UNEP, 2015).

Analisanda essas informações, pode se concluir que o turismo tenha mais aspectos negativos e não deva ser incentivado a acontecer. Mas deve-se levar em consideração que o turismo, quando praticado de forma sustentável, permite a proteção das áreas naturais, podendo até reduzir os impactos negativos.

\subsection{2 - Impactos Positivos do Turismo Sustentável}

O turismo pode ser um importante aliado na preservação ambiental. Uma das contribuições que ele pode trazer são as receitas originadas de taxas para entrada nos atrativos serem realocados para a proteção e gestão de áreas ambientalmente frágeis (UNEP, 2015).

As próprias agências governamentais podem contribuir para 0 recolhimento de receitas oriundas de taxas de utilização, imposto de renda, imposto sobre vendas, taxas de licença para atividades ambientais dentre outros, que podem ser reinvestido na localidade turística.

A boa gestão ambiental das instalações pode aumentar ainda mais o potencial turístico, uma vez que muitos turistas estão mais criteriosos na escolha dos locais que oferecem bem estar, com um menor impacto no meio ambiente. Mas, isso só é possível por meio do planejamento visando um turismo sustentável como será visto mais adiante. Técnicas menos poluentes de produção, como os edifícios verdes (utilizando energia mais eficiente, materiais não poluentes na construção, sistema de tratamento de esgoto, dentre outros) podem ser ferramentas importantes para se utilizar posteriormente no marketing do atrativo ou hotel. 
O turismo tem a grande vantagem de ser possível a realização de sensibilização ambiental em suas atividades, principalmente o turismo de natureza. Pode ocorrer um aumento da consciência para a preservação ambiental e em alguns casos, mudanças de hábitos do turista que também é cidadão e pode disseminar isso em suas localidades. O turismo pode desempenhar um papel importante no fornecimento de informações e à sensibilização dos turistas para as consequências ambientais de suas ações.

E para que seja considerado sustentável, o turismo deve incorporar os princípios e práticas de consumo sustentável, isto é, devem ser incluídos produtos que foram feitos utizando técnicas de produção mais limpa e serviços que são fornecidos de uma forma que minimize os impactos ambientais.

A seguir se verá alguns exemplos de como o turismo contribuiu para localidades antes ambientalmente ameaçadas:

- No Havaí novas leis e regulamentos foram promulgadas para preservar a floresta tropical havaiana e para proteger espécies nativas. O Havaí se tornou um centro de pesquisas sobre sistemas ecológicos e o turismo foi o principal fator motivacional para essas ações;

- Um resort na República Dominicana, o Grupo Punta Cana, é responsável por atrair um grande número de turistas de luxo na região. Em sua construção eles preservaram 10 mil hectares de terras como reserva natural com árvores frutíreras, 11 nascentes cercadas por floresta tropical. Aos turistas são permitidas a exploração por trilhas que conduzem a praia por manguezais, lagoas de água doce e nascentes, dentre outras ações de preservação;

- O turismo também tem tido bons resultados na conservação e proteção dos animais selvagens na África, América do Sul, Ásia. Muitos países tem estabelecido reservas de vida selvagem criando leis rigorosas para proteção da natureza local. Como resultado da medida, vários animais que antes estavam em vias de extinção, começaram a aparecer novamente nos ambientes naturais;

- A Eco-escuela de espanhol é uma escola de línguas espanhola criada em 1996 como parte de um projeto de conservação internacional na 
aldeia Guatemalteco de San Andrés. A escola combina cursos de línguas individuais com oportunidades de ficar em casa da comunidade local, empregando cerca de 100 habitantes dos quais 60\% estavam envolvidos em extração de madeira ilegal e caça. Um estudo de 2000 mostrou que a maioria reduziu significativamente as práticas ilegais.

Estes são apenas alguns exemplos de como o turismo pode auxiliar na preservação ambiental. Algumas medidas regulatórias ajudam a compensar os impactos negativos, como por exemplo, o controle do número de turistas dentro de uma determinada área.

O turismo pode contribuir consideravelmente para a economia local, tornando-se até a principal fonte de recursos e arrecadações de uma dada localidade, fazendo com que mude o padrão de vida de muitos moradores. Mas ele precisa ser bem gerido para se maximizar os efeitos positivos e minimizar os impactos negativos.

A OMT afirma que o desenvolvimento de turismo sustentável requer a participação de todas as partes interessadas e destaca que deva existir uma forte liderança política que garanta uma ampla participação e construção de consenso. E para o sucesso dessas ações, essa organização ainda afirma que o processo deve ser contínuo e requer constante monitorização dos impactos para que sejam introduzidas medidas preventivas e/ou corretivas (RODRIGUES et al, 2014).

\section{4 - Ecoturismo}

O início do ecoturismo, segundo Jesus (2010), se deu nos anos de 1960 quando se tentou controlar a expansão do turismo de massa, aqui definido como tipo de turismo de aglomeração, enfatizando a necessidade de comportamento mais comedido como forma de mitigar os impactos negativos advindos com o turismo. 
Segundo Weaver (2001) para se classificar um destino como ecoturístico, três elementos devem estar presentes. Primeiro, o foco da atração deve ser natural, ou seja, um turismo baseado na natureza. Em segundo lugar, deve-se enfatizar o aprendizado como um resultado da interação entre o homem e o ambiente natural. E por fim, a sustentabilidade local, que segundo o autor, o desejo de compreender e apreciar os atrativos naturais deve assegurar que esses atrativos não sejam ambientalmente impactados.

O autor traz ainda uma análise comparativa entre dois perfis de viagem ecoturística. O primeiro, chamado por ele de "Hard" ou "forte" em tradução literal ou ainda o "Soft" ou "Leve" em português. A seguir as características de cada um desses perfis são apresentadas na TAB. 3.1:

Tabela 3.1: Características do ecoturismo ativo e passivo.

\begin{tabular}{|c|c|}
\hline \\
\hline $\begin{array}{ll}\text { Forte (ativo) } & \text { Espectro do Ecoturismo } \\
\text { Forte compromisso ambiental } & \text { Moderado compromisso ambiental }\end{array}$ & \\
\hline Sustentabilidade em constante aprimoramento. & Sustentabilidade em estado estacionário \\
\hline 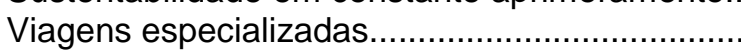 & ..............Viagens com multi-propósitos \\
\hline Viagens longas................... & W.................. Viagens curtas \\
\hline Grupos pequenos de turistas... & ...Grupos com grande número de turistas \\
\hline Fisicamente ativa..... & ...Fisicamente passiva \\
\hline Poucos ou nenhum serviços esperados.. & ........Serviços esperados \\
\hline Énfase na experiência pessoal.... & .............Ênfase na interpretação \\
\hline
\end{tabular}

Fonte: Weaver (2001) adaptado pela pesquisadora.

Cobbinah (2015) destaca que existem alguns teóricos (como Courvisanos e Jain, 2006; Drumm e Moore, 2002; Wheeller, 1993) que argumentam que o ecoturismo é apenas uma tática de marketing, e que os objetivos do ecoturismo não são seguidos por muitos, resultando no mau uso do conceito para atrair turistas conscientes a programas turísticos com a bandeira do ecoturismo, que muitas vezes geram impactos ambientais e sociais negativos. O mesmo autor destaca outros autores (como por exemplo, Courvisanos e Jain, 2006; Donohoe e Needham, 2006) que defendem que devido à inconsistência no significado do ecoturismo, expressaram preocupação sobre a lacuna cada vez maior entre a teoria e a prática do ecoturismo, que, até certo ponto, tem sido impraticável. 
Em busca de definições do termo, Cobbinah (2015) argumenta que há um conjunto de princípios baseados em valores que são frequentemente associados com o conceito de ecoturismo, incluindo a conservação/preservação, ética, sustentabilidade, educação, benefícios econômicos. Mas o autor afirma que na prática, a impressão que permeia é do fracasso dos governos, agências de conservação, organizações não governamentais (ONG) e comunidades locais para fazer qualquer ação sobre efetivação dos princípios básicos do ecoturismo.

O autor classifica o ecoturismo em cinco princípios fundamentais: conservação do meio ambiente, preservação cultural, participação da comunidade, benefícios econômicos e emprego/capacitação para os grupos vulneráveis (FIG. 3.1).

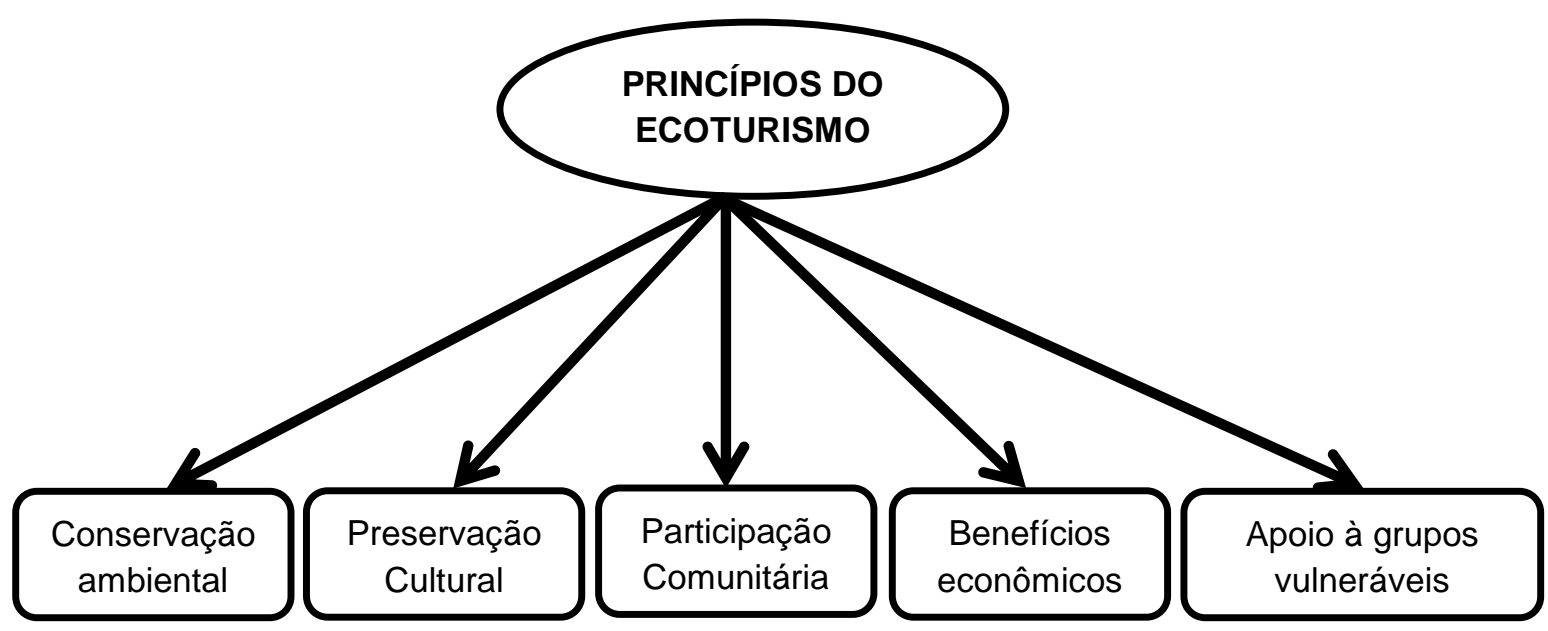

Fonte: COBBINAH, 2015

Figura 3.1: Princípios fundamentais do ecoturismo.

De acordo com Machado (2005), no Brasil, foi realizada uma ação interministerial onde o Instituto Brasileiro do Meio Ambiente e dos Recursos Renováveis (IBAMA) e o Instituto Brasileiro de Turismo - Embratur, se reuniram e classificaram o ecoturismo como uma forma estratégica de se almejar o desenvolvimento sustentável: 
É um segmento da atividade turística que utiliza, de forma sustentável, o patrimônio natural e cultural, incentiva sua conservação e busca a formação de uma consciência ambientalista através da interpretação do ambiente, promovendo o bem-estar das populações envolvidas (MACHADO, 2005).

O Ministério do Turismo - MTUR (2008) destaca que o Ecoturismo deve utilizar o patrimônio natural e cultural de forma sustentável sendo ecologicamente suportável em longo prazo, economicamente viável, ser ética e socialmente equitativo para as comunidades locais. Para isso: "Exige integração ao meio ambiente natural, cultural e humano, respeitando a fragilidade que caracteriza muitas destinações turísticas".

Além disso, o mesmo documento destaca que a atividade ecoturística pressupõe reflexão e integração do homem e ambiente, em uma inter-relação vivencial com o ecossistema, com os costumes e a história local:

\begin{abstract}
Sob esse enfoque, o Ecoturismo caracteriza-se pelo contato com ambientes naturais, pela realização de atividades que possam proporcionar a vivência e o conhecimento da natureza e pela proteção das áreas onde ocorre. Ou seja, assenta-se sobre o tripé interpretação, conservação e sustentabilidade. Assim, o Ecoturismo pode ser entendido como as atividades turísticas baseadas na relação sustentável com a natureza, comprometidas com a conservação e a educação ambiental. (MTUR, 2008).
\end{abstract}

Ainda se deve considerar que algumas características devem estar presentes em destinos ecoturísticos, a saber, segundo o MTUR (2008):

- Atividades praticadas: fala-se em turismo que a atividade não se baseia somente na experiência no atrativo e sim, em todo um conjunto de meios que compõe a atividade, tais como: hospedagem, transporte, alimentação, recreação, entretenimento, operação, agenciamento, recepção, guiamento, dentre outros. O ecoturismo necessita que haja uma conscientização de todos esses segmentos do turismo para que seja praticado adequadamente. Eles devem levar em consideração aspectos construtivos das instalações em relação ao porte, estilo arquitetônico e materiais utilizados. Além disso, os meios e vias de transporte de baixa potencialidade de degradação e poluição devem ser 
seguidos. Assim como a atividade de observação de animais devem ser estudadas as características da fauna e flora previamente, possuir técnicas de interpretação ambiental, além de possuir guias ou condutores locais especializados;

- A escala: o volume e a intensidade do fluxo turístico devem ser analisados previamente para que não haja sobrecarga de uso. Refere-se aqui a necessidade de realização do estudo da capacidade de carga do atrativo turístico de forma a mensurar o número máximo de pessoas que devem visitar o local por dia;

- Proteção e conservação dos recursos naturais: deve-se dispor de um conjunto de medidas planejadas, organizadas e gerenciadas de forma sistêmica, que sejam capazes de promover a conservação, recuperação, preservação e manejo da área turística. Para que isso ocorra é necessário a orientação de instrumentos reguladores como normas, regras, dentre outros; licenciamento ambiental para que se possa instalar atividades e projetos com objetivo de minimizar os impactos negativos; zoneamentos ambientais de forma a destacar o que é e o que não é permitido em áreas naturais; utilização de tecnologias limpas como geração de energia de baixo impacto (solar e eólica), tratamento de resíduos líquidos e sólidos, reutilização de água, entre outros;

- A Paisagem: a paisagem é condição sine qua non para que o turismo ocorra. Dessa forma, deve se buscar infraestrutura, equipamentos e serviços que sejam harmônicas com o meio ambiente de forma a fortalecer a identidade local, seja nos aspectos físicos, biológicos (fauna e flora) ou culturais;

- Interpretação ambiental: essa ação trata-se de proporcionar o entendimento do ambiente natural, despertando a atenção e o interesse do visitante em relação à natureza e à cultura, de forma a esclarecer dados, fatos, que não são claros ao simples olhar. Além disso, serve como forma de sensibilizar e conscientizar em relação às questões ambientais, como forma estratégica de educação ambiental. Torna-se um excelente caminho para proporcionar oportunidade de trabalho e renda para a comunidade local, promovendo a interação entre turistas e comunidade local; 
- Educação Ambiental: a educação ambiental é entendida como um processo pelo qual o indivíduo e a coletividade constroem valores sociais, conhecimentos, habilidade, atitudes e competências voltadas para a conservação do meio ambiente. Em turismo essa é uma prática mais do que necessária para que o visitante possa vivenciar os atrativos locais sem que haja uma vivência insustentável.

Todas essas características apresentadas acima devem ser levadas em consideração pelos locais que planejam realizar práticas ecoturísticas. E aos que já realizam, deveriam se adaptar as essas orientações dadas pelo Ministério do Turismo para que houvesse um turismo sustentável em locais com potenciais naturais.

Nesse sentido o ecoturismo - aqui entendido como o tipo de turismo adequado em habitats naturais que enfatiza o cuidado para não alterar a integridade do ecossistema, ao mesmo tempo em que produz benefícios econômicos para a população local (GOELDNER, RITCHIE, MCINTOSH, 2002) - se apresenta como uma ferramenta de desenvolvimento sustentável que oferece práticas operacionais de vivência do indivíduo ou de um grupo que afetam suas atitudes e valores em relação ao equilíbrio, conservação e uso do meio ambiente, bem como no reconhecimento dos impactos da atividade de exploração turística na estética e cultura existente.

\section{5 - Indicadores}

Segundo Aquino (2014) a grande discussão que permeia em torno da sustentabilidade é como mensurar a sustentabilidade para retirá-la do campo subjetivo em que muitas vezes é percebida. E para auxiliar isso, surgem então os indicadores, que podem permitir avaliar a sustentabilidade de diferentes sistemas. Essa ideia surgiu na Conferência Mundial de Meio Ambiente (Rio-92) conforme documento final, a Agenda 21. "A proposta era definir padrões sustentáveis de desenvolvimento que considerassem aspectos ambientais, econômicos, sociais, éticos e culturais" (AQUINO, 2014; SICHE et al., 2007). 
Um indicador é então, uma ferramenta que permite a obtenção de informações sobre uma dada realidade. Tem como principal característica o poder de sintetizar um conjunto complexo de informações retendo apenas 0 significado essencial dos aspectos analisados. É visto ainda como uma resposta sintomática às atividades exercidas pelo ser humano dentro de determinado sistema (MARZALL; ALMEIDA, 1999).

De acordo com Soares et al. (2013) a Organization for Economic Cooperation and Development - OECD considera os indicadores como um parâmetro, ou valor derivado de parâmetro que informam dados sobre um fenômeno com uma extensão significativa. Os autores destacam que os indicadores podem ser considerados como variáveis que juntas podem representar o quadro de referência e que após analisados mostrarão a realidade de um dado geográfico. Os autores ainda citam Tunstall (1994) para destacar as cincos principais funções dos indicadores: avaliar as condições e tendências; comparar lugares e situações; avaliar condições e tendências em relação às metas e aos objetivos; prover informações de advertência e antecipar futuras condições e tendências.

Jannuzzi (2005) corrobora esse conceito dizendo que um indicador pode subsidiar as atividades de planejamento público e a formulação de políticas sociais nas diferentes esferas do governo, possibilitando o monitoramento das condições de vida e bem estar da população por parte do poder público e da sociedade civil, permitindo ainda 0 aprofundamento das investigações acadêmicas.

Para que haja uma melhor compreensão conceitual, é preciso uma diferenciação entre dois conceitos que parecem a princípio convergentes, mas que na verdade são diferentes: índices e indicadores. Os índices são os valores agregados no final de todo um procedimento de cálculo onde se utilizam, inclusive, indicadores como variáveis que o compõem por meio de cálculo, bases científicas e métodos adequados. Já os indicadores formam um parâmetro selecionado e considerado isoladamente ou em combinações com outros para analisar uma condição do sistema. Logo, os indicadores são normalmente utilizados como pré-tratamento aos dados originais, enquanto os índices correspondem a um nível superior de agregação de um jogo de indicadores ou variáveis (SICHE et al., 2007). 
Soares Júnior (2008) cita o IDH e o IQV como dois possíveis indicadores. Por sua vez, indicadores de felicidade e saúde, para o autor são tratados de maneira subjetiva.

Dentro dos indicadores de desenvolvimento, destaca-se o IDH. Este índice tem sido utilizado mundialmente como importante ferramenta padronizada para medida do bem-estar de uma população e vem sendo usado desde 1993 pelo PNUD. No entanto, é um indicador que apenas contempla variáveis da longevidade, educação e renda. Segundo Veiga (2005), o processo de desenvolvimento é muito mais amplo e mais complexo do que qualquer medida sumária conseguiria captar, mesmo quando completada com outros índices.

Existem muitos indicadores que podem ser usados. Nesse trabalho, serão abordados alguns desses indicadores, a saber, o Índice de Desenvolvimento Humano (IDH), o Índice de Qualidade de Vida (IQV), A Pegada Ecológica do Turismo ou Tourism Ecological Footprint (TEF).

\subsection{1 - Os indicadores da ONU}

Como foi visto anteriormente, a ONU possui um importante papel nas definições conceituais e parâmetros para análise do desenvolvimento sustentável. O Programa das Nações Unidas para o Desenvolvimento (PNUD) ajuda na construção de nações que possam ser capazes de resistir a crises, sustentando e conduzindo um crescimento capaz de melhorar a qualidade de vida da população (PNUD, 2015).

No ano de 2000, alguns líderes mundiais assumiram o compromisso de alcançar os Objetivos de Desenvolvimento do Milênio, em um conjunto de oito metas que visam transformar o mundo em um lugar mais justo, solidário e melhor para se viver (PNUD, 2015).

Os oito objetivos do desenvolvimento do milênio (ODM) são:

- Redução da pobreza: para o programa são consideradas pessoas em situação de pobreza extrema aquelas que apresentam uma renda média 
de $R \$ 2,36$ por dia, ou $R \$ 71,75$ por mês. Segundo dados PNUD, ainda que a parcela da população mundial considerada nesse patamar de pobreza tenha diminuído de $47 \%$ para $22 \%$, mais de 1,2 bilhões de pessoas ainda se mantem nessa condição. No Brasil houve um grande avanço nessa meta ao passar de $25,5 \%$ da população vivendo abaixo da linha de pobreza na década de 90 para 3,5\% em 2012;

- Atingir o ensino básico universal: essa meta não seria alcançada segundo o Relatório de Desenvolvimento do Milênio em 2013 devido ao ritmo de expansão educacional lento, bem como das disparidades existentes, principalmente com relação a meninas e crianças de zonas rurais. Segundo o relatório, ainda assim houve um crescimento de $80 \%$ para $90 \%$ das crianças matriculadas no ensino primário em países em desenvolvimento. No Brasil, a percentagem de jovens de 15 a 24 anos com pelo menos seis anos completos de estudos passou de 59,9\% em 1990 para $84 \%$ em 2012. O que mostra que houve avanços, mas ainda há um longo caminho para alcançar o objetivo;

- Igualdade entre sexos e autonomia das mulheres: o Relatório de 2013 mostrou que esse objetivo estava próximo de atingir a meta de eliminar as disparidades entre os sexos em todos os níveis educacionais. No Brasil houve um progresso nesse indicador, principalmente quanto ao acesso à educação. De 90 a 2012 a escolarização dos homens no ensino médio aumentou mais que das mulheres. Quanto à participação feminina no trabalho, a percentagem de mulheres em atividades fora da agricultura já era de 42\% em 1992 e passou 47\% em 2012. As mulheres chegam a representar $59,5 \%$ dos empregados no setor não agrícola com educação superior;

- Reduzir a mortalidade na infância: houveram avanços também nesse indicador, pois a taxa mundial de mortalidade na infância caiu $47 \%$ em 22 anos, mas sabe-se que muito deve ser feito para a atingir a meta de $75 \%$ de redução dessa taxa. No Brasil, segundo o Relatório Nacional de Acompanhamento dos Objetivos do Milênio (2013), a taxa passou de 53,7 em 1990 para 17,7 óbitos por mil nascidos vivos em 2011, considerando crianças até 5 anos de idade. A meta também foi 
alcançada para crianças menores de 1 ano de idade, passando de 47,1 para 15,3 óbitos por mil nascidos vivos;

- Melhorar a saúde materna: nos países em desenvolvimento, a mortalidade materna caiu de 440 para 240 óbitos por 100 mil nascidos vivos, ocorrendo uma redução de $45 \%$ entre 1990 e 2010. A meta B que é a percentagem de partos atendidos por profissionais de saúde treinados também não foi atingida, pois alcançou apenas $51 \%$ das gestantes que realizavam no ano menos quatro consultas de pré-natal, percentual abaixo da meta que era $66 \%$. No Brasil a taxa de mortalidade materna caiu $55 \%$. Já em $2011,99 \%$ dos partos foram realizados em hospitais ou outros estabelecimentos de saúde, sendo que $90 \%$ das gestantes fizeram ao menos quatro consultas pré-natais, apontando assim um satisfatório avanço nesse objetivo;

- Combater o HIV, malária e outras doenças: esse objetivo não foi alcançado segundo o Relatório ODM de 2013, pois apenas 55\% das pessoas que necessitavam de tratamento contra o HIV/aids o receberam até 2011. Em contrapartida o número de novas infecções anuais por HIV caiu de 0,09 para 0,06 entre 100 pessoas de 15 a 49 anos. Mas ainda assim a ONU alerta para a infecção de 2,5 milhões de pessoas todos os anos. No Brasil, a taxa de detecção de HIV/aids se estabilizou nos últimos dez anos e o coeficiente de mortalidade pela doença diminui;

- Garantir a sustentabilidade ambiental: o relatório mostrou que há cinco anos antes do prazo a meta de diminuição do percentual da população mundial sem acesso a água potável, pois passou de $24 \%$ para $11 \%$. Houve ainda uma redução de $98 \%$ do consumo de substância que destroem a camada de ozônio. O Brasil cumpriu integralmente a meta por, em 2012, apresentar redução considerável no percentual da população sem acesso à água e ao esgotamento sanitário que caiu abaixo da metade do nível de 1990. Além disso, a população urbana em condições de moradia inadequada caiu de $53,3 \%$ em 1992 para $36,6 \%$ em 2012; e

- Parceria Mundial para o desenvolvimento: um dos principais indicadores tem apresentado queda que seria a relação entre a renda nacional bruta e o montante comprometido por eles com cooperação e assistência 
internacional. Brasil, Turquia e Emirados Árabes tem aumentado suas iniciativas de assistência internacional, de forma a contribuir para a promoção do desenvolvimento socioeconômico.

Inácio (2010) traz uma leitura sobre a importância das técnicas estatísticas avançadas para melhorarem a condição de vida da população, à medida que sua utilização engloba desde a elaboração até a implementação de políticas e programas nacionais. O autor cita Paris 21 (2010) para frisar:

\begin{abstract}
Por sua vez, estas informações fornecem as evidências necessárias à implementação e ao controle de políticas de desenvolvimento efetivas. Indicam onde os recursos são mais necessários e fornecem meios para avaliar o progresso e medir o impacto de diferentes políticas. Estatísticas de boa qualidade também aprimoram a transparência e a responsabilidade quanto à prestação de contas na elaboração de políticas, dois elementos essenciais para uma gestão pública eficiente e eficaz, pois permitem que os cidadãos avaliem o sucesso de políticas governamentais e desafiem as autoridades a responder por essas políticas.
\end{abstract}

Dessa forma, conhecer os indicadores de sustentabilidade, bem como, buscar sua adequação para níveis locais podem se tornar uma ferramenta de melhoria constante da qualidade de vida da população.

\title{
3.5.2 - 0 Índice de Qualidade de Vida
}

A qualidade de vida tem sido estudada principalmente por duas grandes áreas, a saber, as ciências da saúde e as ciências sociais. Apesar de suscitar muitas discussões sobre a subjetividade conceitual do termo, muitos estudiosos buscam desenvolver metodologias que possam mensurar esse conceito, transformando-o em um conceito mais concreto.

Como foi visto anteriormente, a partir do momento em que o PNUD desenvolve o IDH para comparar o nível de desenvolvimento entre países, outros estudiosos iniciaram uma busca por novos índices que permitissem analisar o desenvolvimento humano, as condições de vida e da qualidade de vida de uma dada população. Nahas (2005) destaca que esses novos 
indicadores fortaleceram os vínculos entre desenvolvimento sustentável, justiça social e qualidade ambiental.

O conceito de qualidade de vida introduz uma valorização de desejos almejados por grupos sociais, podendo tornar-se referência para superação de diferenças, permitindo comparações por meio de indicadores. Keinert et al. (2012) citam Herculano (1998) para definir qualidade de vida como a soma das condições econômicas, ambientais, científico-culturais e políticas coletivamente construídas e postas à disposição dos indivíduos, incluindo a acessibilidade à produção e ao consumo, o acesso aos meios de cultura, ciência e arte, além de existência de mecanismos de comunicação, de informação, assegurando água e ar limpos, higidez ambiental, alimentos saudáveis e ecossistemas naturais.

KEINERT et al. (2012) consideram qualidade de vida relacionada às necessidades do ser humano, nesse aspecto podem ser citadas a saúde e educação, enquanto os aspectos relacionados ao bem-estar são considerados subjetivos para análise. Keinert et al. (2012) afirmam ainda que alguns autores consideram o conceito de qualidade de vida como algo construído socialmente e dessa forma, cada sociedade teria uma conceituação diferente.

Pereira et al. (2007) trazem um levantamento conceitual sobre qualidade de vida:

\begin{abstract}
Dependendo da área de interesse o conceito, muitas vezes, é adotado como sinônimo de saúde (...), felicidade e satisfação pessoal (...), condições de vida (...), estilo de vida (...), dentre outros; e seus indicadores vão desde a renda até a satisfação com determinados aspectos da vida. Devido a essa complexidade, (...) a qualidade de vida apresenta-se como uma temática de difícil compreensão e necessita de certas delimitações que possibilitem sua operacionalização em análises científicas.
\end{abstract}

Os mesmos autores ainda discutem uma conceituação mais holística para qualidade de vida, aonde sai-se do conceito biomédico de bem estar na saúde quanto à sobrevivência das pessoas, e passa-se à uma conceituação mais ampla remetida a representações sociais mais subjetivas como bemestar, felicidade, amor, prazer, realização pessoal, sem deixar de analisar aspectos objetivos como satisfação das necessidades básicas e/ou criadas pelo grau de desenvolvimento econômico e social de uma dada sociedade. 
Dentro desse contexto holístico e interdisciplinar, há alguns estudos que correlacionam a atividade turística de uma dada região à qualidade de vida proporcionada a comunidade que se beneficia dela (KIM et al., 2013; BRANDÃO, BARBIERI, REYES-JUNIOR, 2013; SILVA, CARVALHO, 2014), bem como, a sustentabilidade do local (Weaver, 2005; FEITOSA e GOMEZ, 2013). Dessa forma, a atividade turística pode beneficiar a qualidade de vida da população do destino turístico e ainda auxiliar na sustentabilidade ambiental, econômica e social do lugar.

Uysal et al. (2015) afirmam que a eficácia do turismo como parâmetro de tomada de decisões para implementação de políticas de qualidade de vida para redução de pobreza nas comunidades receptoras, revitalização do patrimônio cultural, preservação e proteção dos recursos naturais tem permeado os estudos acadêmicos. Mas, que para sua efetividade comprovada é preciso a inovação e a análise das questões e mostrar experiências bem-sucedidas.

Os autores ainda afirmam que, apesar das pesquisas mostrarem que a comunidade tende a perceber o impacto econômico trazido pelo turismo como positivo, também há uma preocupação com os impactos sociais e ambientais que, algumas vezes tendem a ser vistos como negativos, comprometendo assim a qualidade de vida daquela comunidade. Vale lembrar que o turismo pode propiciar uma maior qualidade de vida da comunidade a partir do momento em que as esferas públicas investem em melhorias na cidade para a recepção ao turista e essa mesma infraestrutura turística pode ser utilizada pelas comunidades que lá habitam.

Kim et al. (2013) afirmam que o impacto do turismo no bem-estar da comunidade está ligado ao desenvolvimento do ciclo do turismo no local (introdução, crescimento, maturidade e/ou declínio). Isto porque, por exemplo, em cidades que o turismo não foi bem planejado, há uma perda da qualidade de vida da população com o desenvolvimento do turismo, isto é, na medida em que ele vai crescendo, por exemplo, com o auge do turismo na alta temporada trazendo consigo os impactos negativos já analisados nesse estudo e, consequentemente, não ser tão bem visto pela comunidade receptora como na fase inicial.

Acredita-se, então, que é importante conhecer todas essas percepções dos moradores para que se (re) avalie o (re) investimento em uma atividade e 
em uma região com potencial turístico. Dessa forma, conhecer a percepção dos moradores sobre sua qualidade de vida se torna importantíssimo para que sejam moldadas novas políticas públicas e investimentos na região.

\subsection{3 - A Pegada Ecológica do Turismo}

As publicações sobre Pegada Ecológica (PE) surgiram pela primeira vez no início dos anos 90 por William Rees e Mathis Wackernagel (AGOSTINHO E PEREIRA, 2013) quando Rees em 1992 a descreveu como uma ferramenta que permite avaliar as condições mínimas para a sustentabilidade. A ferramenta pode estimar pelo cálculo da área de terra, quanto seria necessário produzir ou criar produtos consumidos e suportar a quantidade de resíduos produzidos pela população estudada. Dessa forma, a ferramenta permite o entendimento da carga produzida sobre o meio ambiente causada pela atividade em estudo.

Em outras palavras Cidin e Silva (2004) descrevem que a pegada ecológica contrasta o consumo dos recursos pelas atividades humanas com a capacidade de suporte da natureza e mostra se os impactos causados são ou não sustentáveis a longo prazo.

A Pegada Ecológica tem sido defendida por alguns estudiosos como um importante aliado na análise e busca para o desenvolvimento de um turismo sustentável (Hunter e Shaw, 2007; Castellani e Sala, 2012; Munday, Turner e Jones, 2013; Nakajima e Ortega, 2016).

Hunter e Shaw (2007) afirmam que a Pegada Ecológica foi criada para analisar o impacto ambiental agregado em termos de pressão sobre a biosfera global. A sua utilização no contexto do Turismo Sustentável ainda é pouco estudada. Os autores ainda destacam que o turista deixa de gerar a pegada ecológica em sua localidade quando estão em viagem ao destino turístico por ele escolhido.

Normalmente a PE realiza cálculos combinando a utilização de energia, alimentos, matérias-primas e água e também para mensurar os impactos 
relacionados ao transporte e à produção de resíduos, bem como a perda de terra produtivas associadas à construção de edifícios, estradas e outros aspectos do ambiente construído (HUNTER e SHAW, 2007). Os fatores de conversão para a unidade de hectares globais (gha) são utilizados para expressar a magnitude do impacto em todos os componentes (TEIXEIRAS, 2012).

As viagens de turismo, apesar de serem uma importante área da indústria do turismo, são pouco estudadas no que se refere a impactos ambientais de turistas, e menos ainda sobre as implicações de fornecimento de energia, comida e água para atender as demandas locais das cidades turísticas em época de alta temporada, segundo Hunter e Shaw (2007).

Munday, Turner e Jones (2013) afirmam que os gestores públicos têm em suas mãos difíceis tomadas de decisões em espaços turísticos quando há poucas informações sobre a relação econômica, social e os custos ambientais em destinos turísticos. Dessa forma, a pegada ecológica tem sido utilizada pela comunidade científica por sua fácil compreensão na maneira de expressar os resultados finais: hectares de terra (AGOSTINHO e PEREIRA, 2013).

Em 2002 Gössling et al. realizaram uma adaptação para a utilização da metodologia da Pegada Ecológica no turismo feita a partir do momento em que criam uma medida para determinar a quantidade de terras bioprodutivas, terras construídas e terras de energia fóssil necessárias para suportar a atividade turística. Eles aplicaram a metodologia adaptada nas ilhas de Seychelles, que ficam no continente Africano. Foi percebido que a pegada ecológica atribuída ao transporte aéreo era muito alta. Os resultados levaram a análises políticas de modo a desestimular o transporte aéreo em excesso para que se buscasse a sustentabilidade local (HUNTER e SHAW, 2007).

Foi estabelecido por Gössling et al. (2002) quatro categorias de consumo, a saber: transportes, alojamento, atividades de lazer e alimentação e consumo de fibras. Podendo possuir um ou mais tipos de terras associadas a cada categoria, conforme poderá ser percebido mais adiante no detalhamento da metodologia. Para a Pegada Ecológica do Turismo as terras consideradas foram: terras bioprodutivas, terras construídas e terras de energia fóssil. 
$\mathrm{Na}$ categoria transporte considera-se terras de energia fóssil (queima de combustíveis fósseis nos transportes), bem como as terras construídas para atendimento ao transporte, como, por exemplo, os aeroportos. Já na categoria de acomodação estão relacionadas as terras construídas na construção de hotéis, pousadas, restaurantes; e as terras de energia fóssil com o consumo energético diário dos mecanismos de hospedagem. A categoria atividades está vinculada tanto com terras de energia fóssil (demanda de energia nas atividades de lazer) quanto com terras construídas (construção de parques, áreas de recreação etc.). E a categoria alimentação e consumo de fibras está associada a terras bioprodutivas (florestas, áreas de cultivo, pastagens, pesca), segundo Feitosa e Gomez (2013).

As mesmas autoras ainda destacam que a proposta de adaptação da PE para o turismo feita por Gössling et al. (2002) considera a categoria acomodação como toda área requerida para a construção de quartos/apartamentos, jardins, restaurantes dentre outros. E as terras de energia fóssil dessa categoria equivalem ao uso da energia (seja aquecimento, ar condicionado, cozinha, iluminação, limpeza e etc). Já na categoria atividades os autores consideram as visitações aos locais recreativos, avaliando a quantidade de terra e energia que essas atividades demandam para serem realizadas. Logo, a unidade de mensuração utilizada é área ocupada em hectares. E por fim, a categoria de alimentos e fibras mensura o total de terras de cultivo, espaços aquáticos produtivos, florestas e pastagens necessárias para a produção de alimentos e fibras consumidas pelo turista.

Feitosa e Gomez (2012) propuseram uma adaptação nos estudos de Gössling et al., por considerarem que há uma lacuna na análise dos autores originais da Pegada Ecológica do Turismo (PET) por desconsiderarem as categorias de consumo de água e geração de resíduos sólidos. Em relação ao total de água consumida pelo equipamento hoteleiro, as autoras afirmam que ela pode ser transformada em hectare de terra, a medida que, a partir das diretrizes de Wackernagem e Rees em 2002, considera-se que para cada megalitro de água tratada, encanada e distribuída, são lançados na atmosfera 0,37 toneladas de dióxido de carbono $\left(\mathrm{CO}_{2}\right)$. Esses gases podem ser 
transformados em hectares considerando que uma tonelada de $\mathrm{CO}_{2}$ é absorvida por 1 hectare de terra.

Quanto a categoria de geração de resíduos sólidos na hotelaria também pode ser transformada em hectares de terra. Considera-se que 0,00135t de resíduos sólidos equivalem a $0,00045 t$ de $\mathrm{CO}_{2}$ e que uma tonelada de $\mathrm{CO}_{2}$ é assimilada por um hectare de terra. 


\section{4 - PROCEDIMENTOS METODOLÓGICOS}

\section{1- $O$ universo e a amostra}

A população estudada foi constituída pelo universo de moradores da cidade de Mateiros / TO, que possui população estimada em 2.524 pessoas (IBGE, 2015). A cidade foi dividida em quatro grandes áreas para que na amostragem houvesse o maior número possível de respondentes e assim evitar, que houvesse direcionamento de resposta de alguma determinada região. A FIG. 4.1 mostra o mapa da cidade e a divisão das regiões.

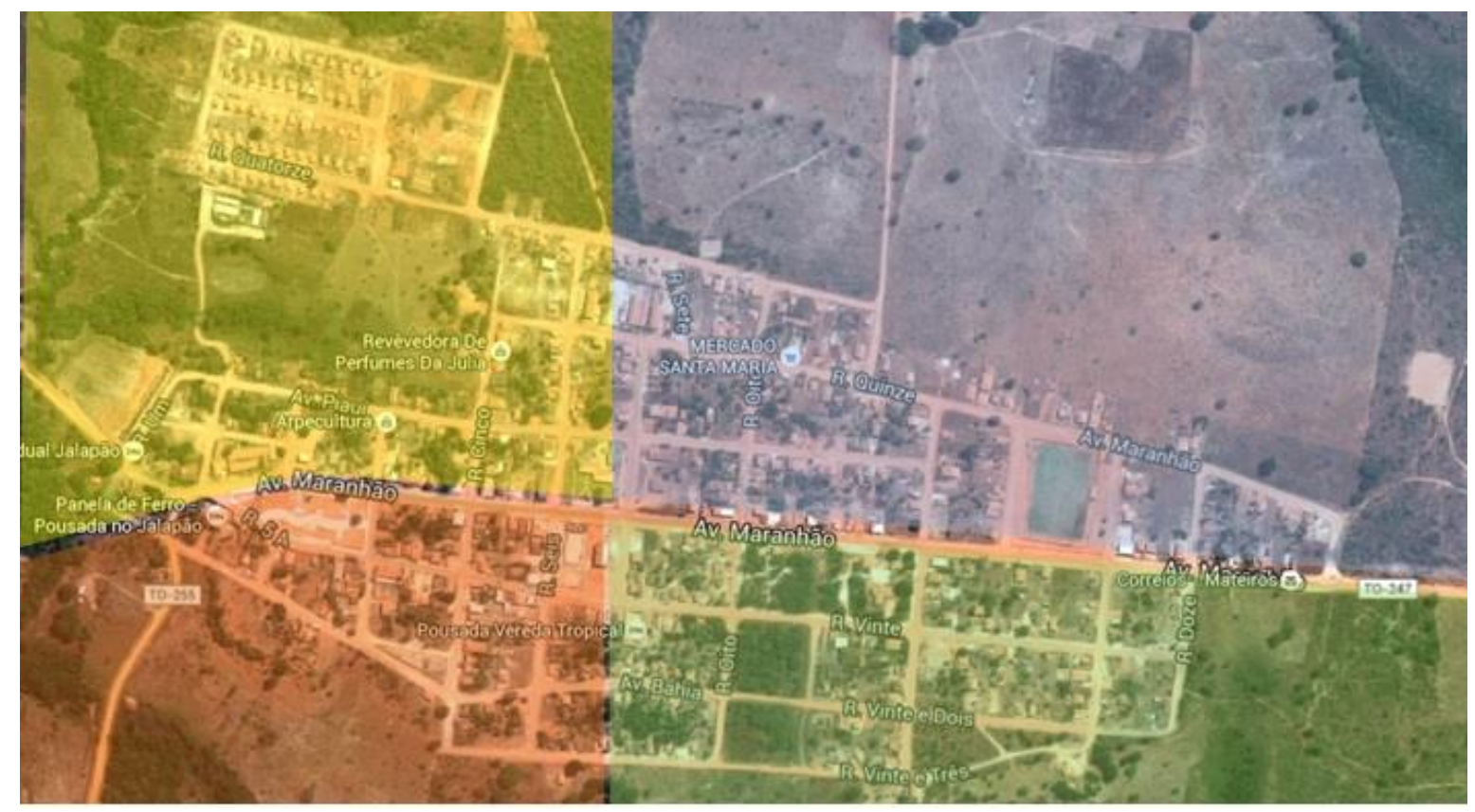

Fonte: Adaptado de Google Maps (2016)

FIG. 4.1 - Mapa da cidade de Mateiros dividido por regiões em que foram realizadas as entrevistas

Como o objetivo foi analisar a qualidade de vida das famílias de Mateiros, realizou-se o cálculo da amostragem pelo número de residências na cidade. $\mathrm{Na}$ prefeitura da cidade não havia dados sistematizados sobre a quantidade de residências existentes na região para que pudesse servir como 
parâmetro. Segundo informações dos representantes da prefeitura (MOKFA, 2014), muitas casas foram abandonadas em algumas regiões da cidade após a construção pelo governo, de residências populares em um dos setores da cidade. Realizou-se então a contagem utilizando as fotos de satélite da região estudada, conforme exibido na FIG. 4.1. Constatou-se que a cidade possui 434 residências, mas o novo bairro possui 57 residências ocupadas. Desta forma, considerou-se que haviam de fato 385 residências nas quais de fato existiam moradores. Dessa forma, foram realizadas 141 entrevistas com residentes na cidade, o que representaria $37 \%$ das famílias moradoras de Mateiros.

Ao se iniciar os procedimentos nas residências, o responsável pela família era convidado a conceder a entrevista. Caso ele não estivesse presente, outro morador da casa, desde que maior de 18 anos, e conhecedor da rotina e história da família, poderia substituí-lo.

As entrevistas ocorreram em dias da semana e finais de semana previamente selecionados de modo a não coincidir com feriados, férias ou eventos na cidade. Tal procedimento foi adotado para que não houvesse influência negativa na disponibilidade dos entrevistados em conceder entrevista e para que o maior número de representantes da família pudesse participar.

\section{2 - 0 Jalapão}

Segundo diagnóstico realizado pela Secretaria de Planejamento do Meio Ambiente do Tocantins - SEPLAN (2006), a área do Jalapão, onde se insere a comunidade Mateiros, é uma região isolada e pouco desenvolvida. Situa-se na porção leste do Tocantins e alcança também os estados do Maranhão, Piauí e Bahia. Os paradoxos da região são predominantemente de natureza ambiental e social. A região do Jalapão compreende uma área espacial de 81,5 mil Km², que faz divisa com os estados Maranhão, Piauí e Bahia (ICMBIO, 2016). Desta área total, 34,1 mil $\mathrm{Km}^{2}$ encontram-se dentro do Estado do Tocantins (FIG. 4.2). Possui uma baixa densidade populacional (entre 0,3 e 0,7 hab. $/ \mathrm{km}^{2}$ ). 

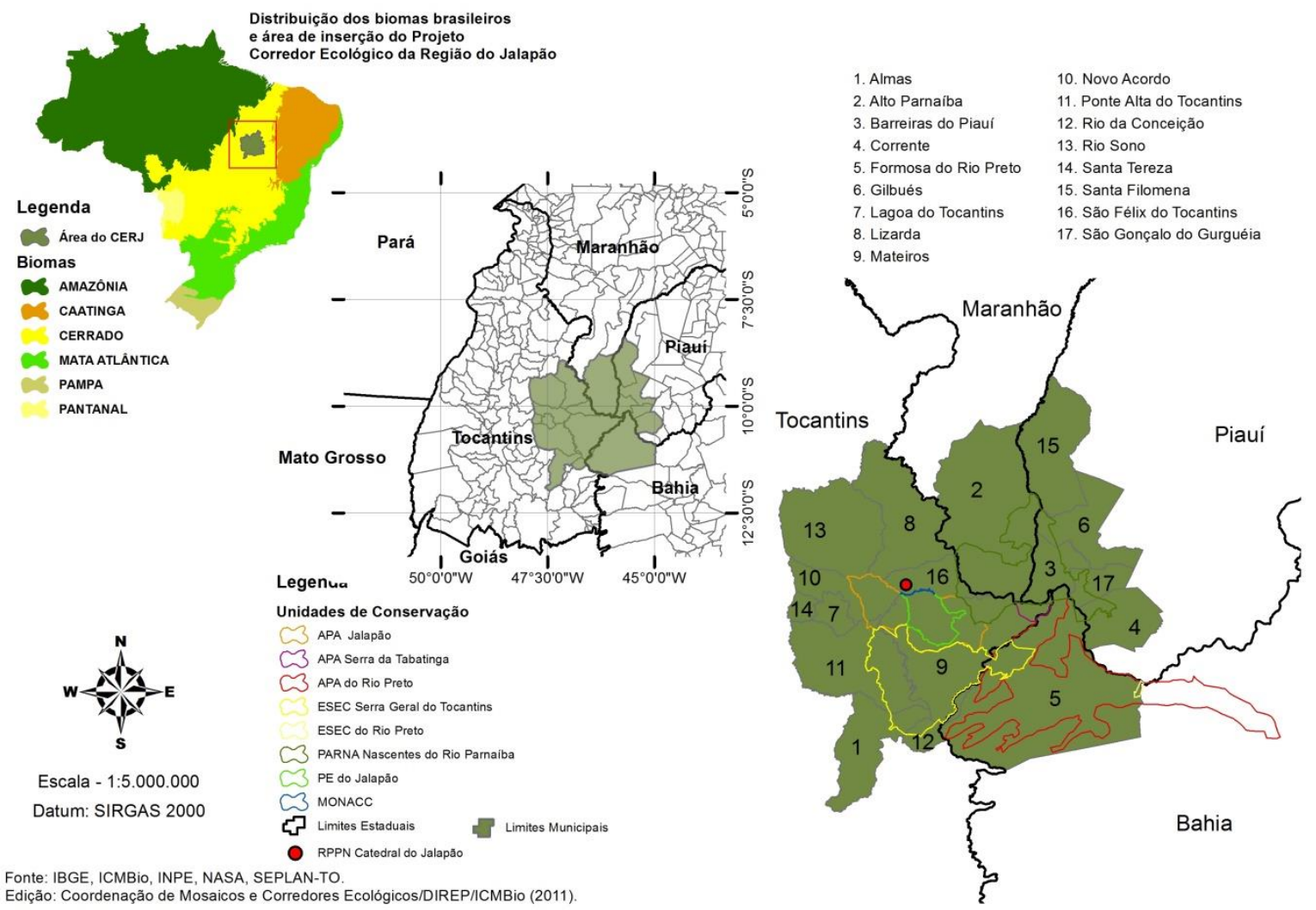

Figura 4.2: Distribuição dos biomas brasileiros e área de inserção do Projeto Corredor Ecológico da Região do Jalapão.

A cidade de Mateiros dista $275 \mathrm{Km}$ da capital do Tocantins, Palmas, sendo essa uma das oito cidades que compõe a região conhecida como Jalapão. A localidade era inicialmente distrito de Ponte Alta do Tocantins do Norte, atual Ponte Alta do Tocantins. Por meio da Lei Estadual nํ251, de 20 de fevereiro de 1991 o distrito de Mateiros torna-se cidade. A região abriga a maior área de proteção ambiental, o Parque Estadual do Jalapão, conhecida como "Deserto das águas" devido à sua aparência desértica, mas com muitas cachoeiras e rios que compõe as belas paisagens do local.

A população local estimada em 2015 de 2.524 habitantes segundo o Instituto Brasileiro de Geografia e Estatística (MESSETI, 2015). Por se encontrarem vários atrativos nas proximidades, a cidade recebe um grande número de turistas na alta temporada.

Em termos sociais, a miséria e a escassez de recursos são iguais para os habitantes daquela área e são justamente os contrastes ecológicos as maiores riquezas do lugar. Opondo-se ao aspecto árido do cerrado campo 
limpo que recobre o solo arenoso do Jalapão, estão as nascentes, rios e cachoeiras que são abundantes em toda parte. Diversas sub-bacias desembocam no Rio Tocantins, entre elas a Bacia do Rio Sono, que se contrasta com o aspecto árido do cerrado. (SEPLAN, 2006). O resultado destes contrastes é uma imensidão recortada por águas límpidas, apresentando um forte potencial turístico, reconhecida pelo Ministério do Meio Ambiente como ponto turístico do Brasil, incluído no Programa de Desenvolvimento do Ecoturismo da Amazônia Legal - PROECOTUR (SANTOS, 2007). Os principais atrativos segundo dados da SEPLAN (2006) são:

- Cachoeira da Velha: possui formato de duas ferraduras com 15 metros de altura, suas águas permitem a prática de rafting.

- Dunas da Serra do Espírito Santo: com mais de 20 metros de altura, envolvidas por veredas, por Córrego das Areias e uma lagoa próxima (FIG. 4.3 e 4.4);

- Cachoeira do Formiga: suas águas cristalinas formam um poço para banho de aproximadamente 8 metros de diâmetro (FIG. 4.5);

- Fervedouro: poço de águas ressurgentes que não permite ao banhista afundar (FIG. 4.6). Este atrativo é cercado de mistérios, que foram estudados por Senna e Magalhães (2008).

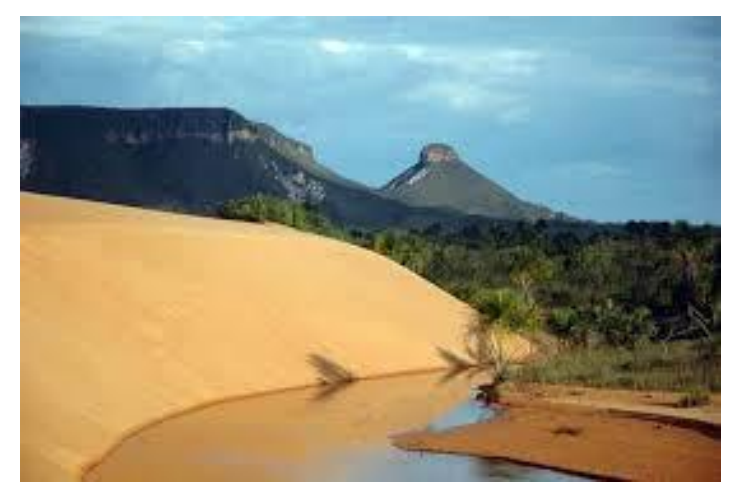

Fonte: SENNA et al., 2015

FIG.4.3 Dunas

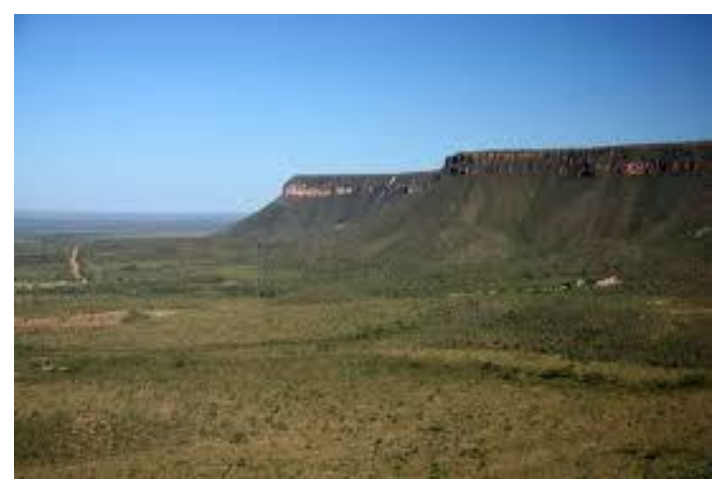

Fonte: SENNA et al., 2015 FIG.4.4 Serra Espirito Santo 


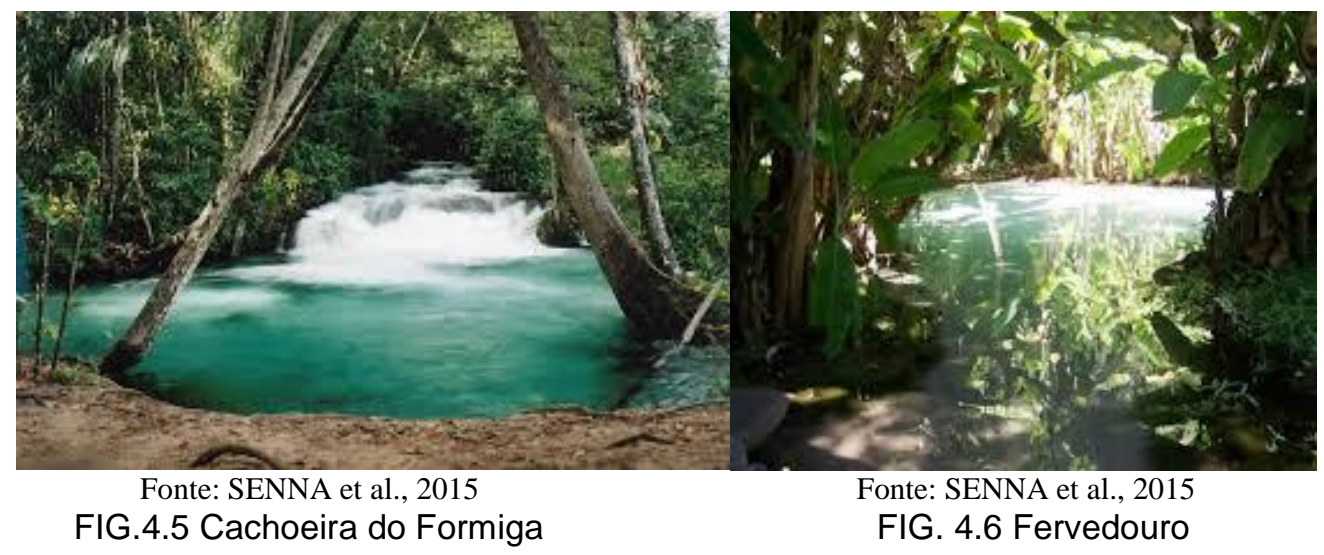

As Unidades de Conservação (UC) encontradas na região se conectam (FIG. 4.2). Destacam-se a Estação Ecológica Serra Geral do Tocantins (716 mil hectares), Área de Proteção Ambiental (APA) do Jalapão (467 mil hectares), APA da Serra da Tabatinga e APA das Nascentes do Parnaíba (quase 730 mil hectares). O conjunto de UC do Jalapão forma uma das maiores regiões de cerrado sob proteção (SCHMIDT, 2005).

Segundo dados de Tocantins (2011), o nome da cidade de Mateiros, distante $341 \mathrm{Km}$ de Palmas - capital do Estado do Tocantins, se deve à grande quantidade de veados mateiros encontrada na região. A cidade de Mateiros concentra a maior parte dos atrativos consagrados do Jalapão. Os principais acessos à cidade se dão pelas estradas TO-030, TO-110 e TO-255 ou ainda pela TO-247 e TO-476 todas não asfaltadas (FIG. 4.7). 


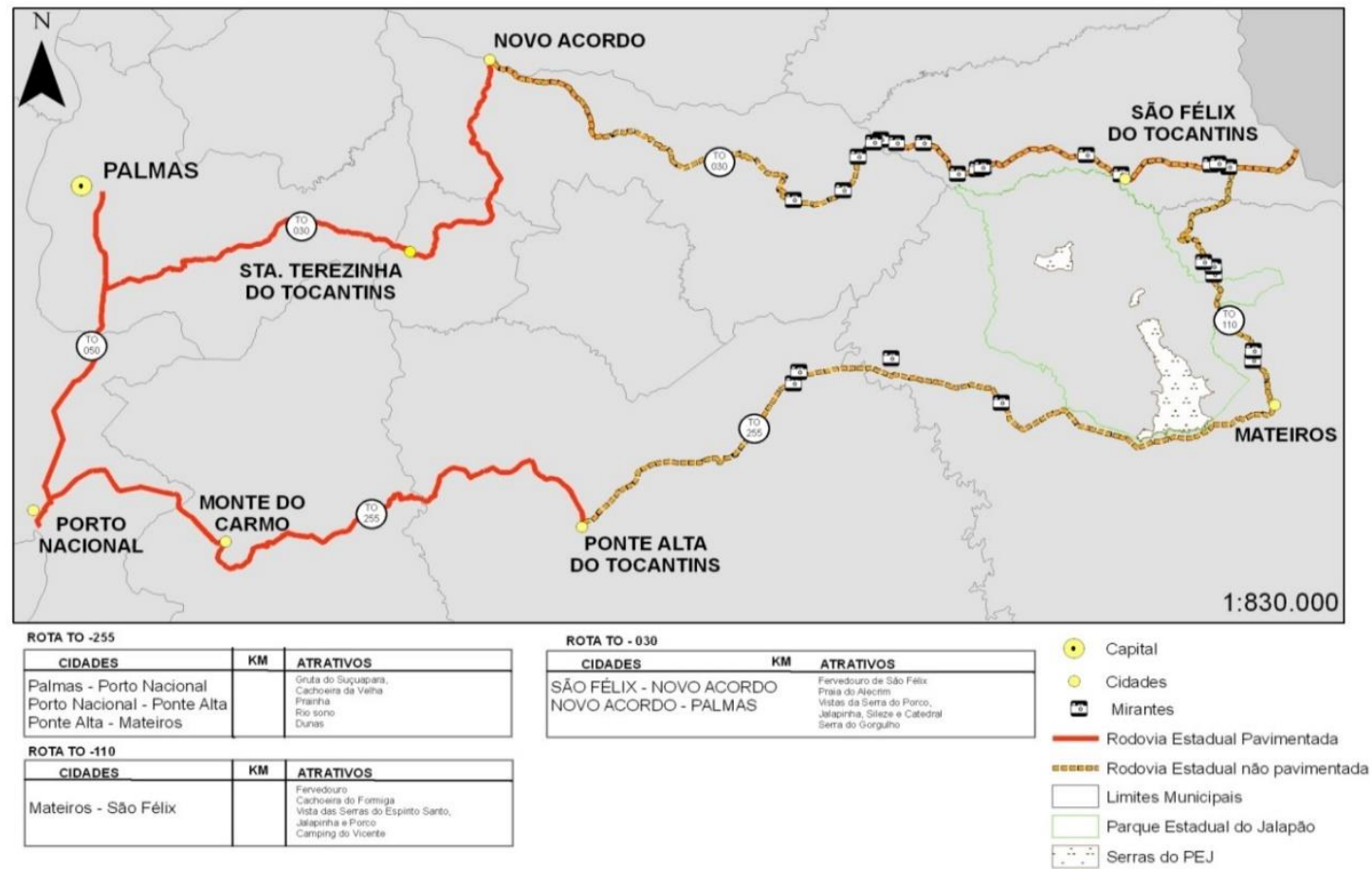

Fonte: Cartilha: Jalapão - Turismo Consciente, 2008.

Figura 4.7 - Mapa com acessos à cidade de Mateiros / Jalapão.

As estradas não são pavimentadas e, em alguns períodos do ano, possuem trechos de difícil acesso, sendo que para se chegar em alguns atrativos é preciso utilizar veículos de tração $4 \times 4$ (FIG. 4.8). No detalhe é possível comparar o tamanho do carro, o qual parece pequeno frente ao tamanho da erosão na estrada. 


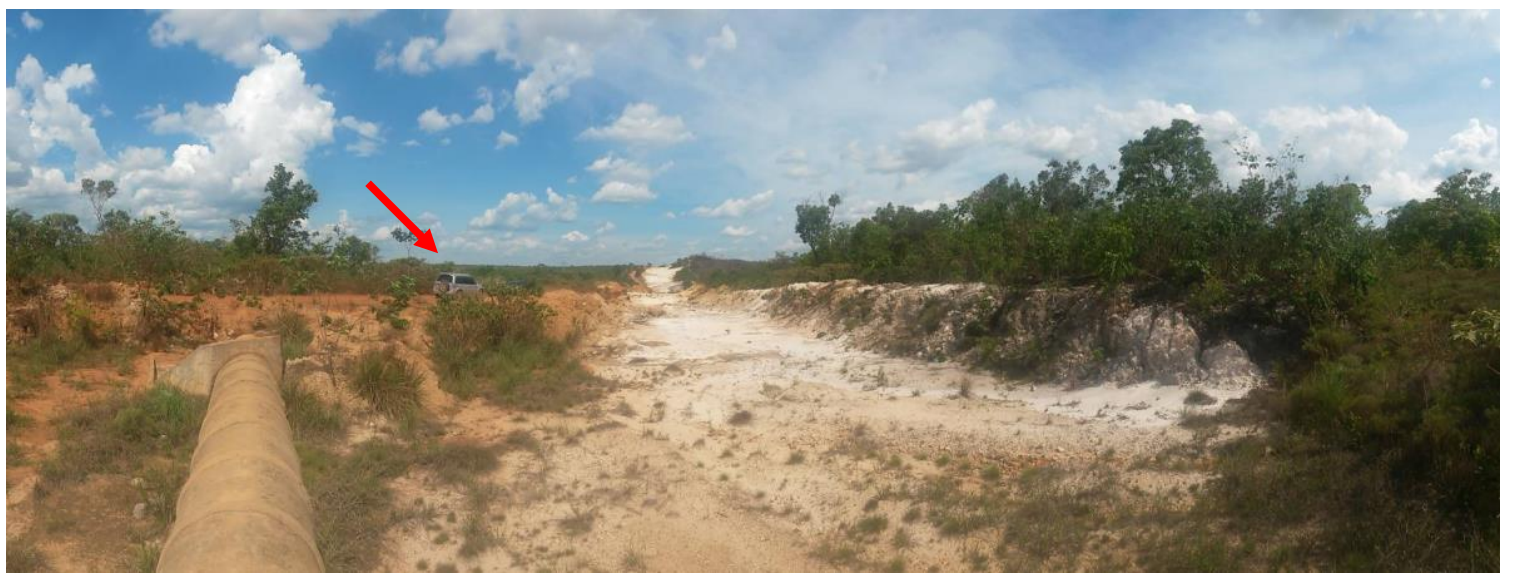

FIG. 4.8 - Condições da estrada via São Félix do Tocantins em setembro de 2014.

A cidade de Mateiros também é responsável pela produção de artesanatos confeccionados com o capim dourado (Syngonanthus nitens) sempre-viva típica da região, tendo como núcleo a comunidade de Mumbuca, que foi reconhecida pelo Ministério da Cultura, por meio da Fundação Cultura Palmares, em 2004, como remanescente das comunidades dos quilombos (SENNA, 2008). Esta atividade, atrelada às ações de recepção aos turistas, vem substituindo as práticas econômicas tradicionais da lavoura e pecuária, o que tem contribuído para a inclusão da comunidade nos programas sociais em função da comunidade permanecer menos dispersa (PIRES; OLIVEIRA, 2006).

Esse mesmo reconhecimento da comunidade, traz também alguns entraves, como por exemplo, a desapropriação dos atrativos turísticos do Parque Estadual do Jalapão. A maioria dos atrativos pertence hoje a proprietários particulares. Eram regiões habitadas pelos pioneiros que acabaram vendo nas belezas naturais, possíveis atrativos turísticos que hoje tornaram-se negócios familiares. Na criação do PEJ, muitos foram informados que seriam desapropriados, uma vez que essa UC objetiva a preservação dos recursos naturais da região, restringindo suas formas de exploração, admitindo assim o seu aproveitamento indireto. Após longos anos de debates judiciais quanto a essa desapropriação, em conversa informal com os proprietários dos atrativos, foi informado que, por suas famílias terem conseguido 0 reconhecimento como remanescentes de quilombolas, eles estavam prestes a 
conseguir a posse da terra e consequentemente poderiam utilizá-la da forma que lhes parecesse conveniente. Crê-se que isso ainda demandará muitos debates.

Em relação aos impactos ambientais percebidos na região do Jalapão, Ferreira (2007) desenvolveu uma análise por meio do método do "Limite Aceitável de Câmbio (LAC)", que vêm ocorrendo nos atrativos e acampamentos utilizados intensamente. Foram analisados aspectos biofísicos, como, por exemplo, quantidade de lixo, raízes expostas e árvores danificadas. Os principais impactos observados foram erosão do solo, abertura de vias de acesso aos atrativos, degradação da vegetação, lixo deixados nos atrativos. A pesquisa demonstra o quão frágil é este ecossistema da região.

Em virtude desta inserção da comunidade como descendentes de quilombolas e produtores das peças de capim dourado e a percepção de impactos ambientais evidentes na comunidade, é importante um estudo sobre como a cidade de Mateiros tem realizado suas atividades de extrativismo e a sustentabilidade local. Esta última possui parcela significativa para a sobrevivência da comunidade, tanto sob os aspectos culturais e sociais como sob os aspectos ligados as condições mínimas de qualidade de vida, tais como, saúde, moradia, trabalho e por consequência de sobrevivência humana como um todo.

\section{3 - Instrumentos de coleta de dados}

A natureza dessa pesquisa é de caráter descritiva, uma vez que procura observar, registrar, analisar e correlacionar dados sem que haja manipulação dos mesmos, conforme descrito por Cervo e Bervian (1996).

Para a realização deste trabalho foram utilizados três métodos de pesquisa distintos: Levantamento dos indicadores de sustentabilidade selecionados para compor o IQV; a Pegada Ecológica do Turismo para avaliar os possíveis impactos ambientais gerados pela atividade turística; e as narrativas orais para compor as perspectivas da cidade de Mateiros/TO quanto à sua própria situação sócio-política, frente à relação com o turismo, inserido 
na região do Jalapão, como alternativa econômica.

Para levantamento de dados primários, foi consolidado um questionário estruturado e um roteiro de perguntas aplicado por residência, abordando tanto a metodologia do Índice de Qualidade de Vida, quanto das narrativas orais. Foram realizadas 141 entrevistas com moradores em suas residências na cidade de Mateiros, sendo o questionário apenas um roteiro de perguntas para as entrevistas, buscando a entrevistadora sanar possíveis interpretações equivocadas por parte dos entrevistados. O questionário foi validado na pesquisa de SANTOS et al. (2007) realizando alguns ajustes, como por exemplo, mudanças nos bens de consumo para adequação ao padrão mais atual (DVD) e padronização da nomenclatura para as diferentes bolsas-auxílio que foram incluídas no Programa Bolsa-Família. Foi ainda aplicado um piloto pela pesquisadora em Abril de 2014, onde foi possível detectar adaptações para a realidade do município.

O grupo de pesquisadores foi dividido em duplas, seguindo a estratégia de Alberti (2004): o primeiro conduziu a entrevista formulando perguntas e ouvindo suas respostas; e o segundo entrevistador ficou responsável pelos elementos de apoio, controlando a gravação da conversa e tomando nota das questões a serem aprofundadas ou esclarecidas.

Como indicador de sustentabilidade, utilizou-se o método adotado por Fernandes (1997, apud LIMA, 2003) e reproduzido por Senna et al. (2008) para mensurar o IQV, que considera: condições de moradia, aspectos sanitários, bens de consumo duráveis, acesso aos meios de comunicação e lazer, saúde, educação e emprego e renda, conforme apresentado na TAB. 4.1. 
Tabela 4.1: Indicadores considerados em cada dimensão selecionada para composição do IQV:

\begin{tabular}{|c|c|c|c|}
\hline \multirow{6}{*}{ INDICADORES } & \multicolumn{3}{|c|}{ DIMENSÕES } \\
\hline & Social & Econômica & Ambiental \\
\hline & $\begin{array}{l}\text { Condições de } \\
\text { moradia }\end{array}$ & Renda & Aspectos sanitários \\
\hline & $\begin{array}{l}\text { Comunicação e } \\
\text { lazer }\end{array}$ & $\begin{array}{c}\text { Bens de consumo } \\
\text { duráveis }\end{array}$ & Meio Ambiente \\
\hline & \multicolumn{3}{|l|}{ Saúde } \\
\hline & \multicolumn{3}{|l|}{ Educação } \\
\hline
\end{tabular}

Foi acrescentado a estes dados o indicador ambiental que constituiu a percepção dos entrevistados sobre o item meio ambiente. Este indicador teve sua medição realizada por meio da coleta de dados primários, obtidos pela aplicação do questionário, referente aos dados coletados para formulação do IQV, junto à comunidade, alcançando-se valores depois do estabelecimento do turismo.

O procedimento de uso do IQV foi realizado segundo Monte et al. (1999) e definido pela equação 4.1 :

$\mathrm{IQV}=\frac{1}{\mathrm{Z}} \sum_{i=1}^{Z}[\mathrm{Ci}]$, onde:

Onde:

IQV = índice de qualidade de vida antes e durante o estabelecimento da atividade turística na cidade de Mateiros/TO;

$\mathrm{Ci}$ = contribuição do indicador ( $\mathrm{i}$ ) no índice de qualidade de vida;

$E v j=$ escore da $-v$ ésima variável, obtido pelo - j ésima família;

$P v j=$ peso da $-v$ ésima variável, definido pelo - j ésima família; 
$v=1,2, \ldots m$ variáveis;

$j=1,2, \ldots n$ famílias;

$i=1,2, \ldots z$ indicadores;

$E$ max $v=$ escore máximo da $-v$ ésima variável;

$P \max v=$ peso máximo da $-v$ ésima variável;

$m$ = número de variáveis;

$n$ = número de famílias;

$z=$ número de indicadores

A consideração para estabelecer o crescimento do índice foi realizada como no Índice de Desenvolvimento Humano - IDH, quanto mais próximo de 1, maior o valor do Índice de Qualidade de Vida na comunidade. Optou-se por estabelecer o seguinte critério para consolidação dos indicadores (PNUD, 2006):

a) baixo nível $-0<\mathrm{IQV}<0,499$

b) médio nível - 0,5 $<\mathrm{IQV}<0,799$

c) alto nível - 0,8 $<\mathrm{IQV}=1,0$

Somando-se a este indicador foram ainda analisados os indicadores das Nações Unidas (ONU, 1996) que foram obtidos por meio de dados primários e secundários junto gestores públicos e Rede Energisa que é a empresa prestadora de serviços elétricos e Saneatins que é a empresa prestadora de saneamento estaduais. Essas entrevistas foram realizadas entre os meses de agosto a dezembro de 2014 , seguindo questionário elaborado (Apêndices A, B e C). Os indicadores da ONU serão apresentados a seguir: 
TABELA 4.2 - Indicadores das Nações Unidas:

SUSTENTABILIDADE SOCIAL

\begin{tabular}{|c|c|c|}
\hline Tema & Subtema & Indicador \\
\hline \multirow[t]{4}{*}{ Equidade } & De Pobreza & $\begin{array}{l}\text { Porcentagem da população vivendo abaixo da linha } \\
\text { da pobreza }\end{array}$ \\
\hline & & Índice GINI de iniquidade \\
\hline & & Taxa de Desemprego \\
\hline & Do Gênero & $\begin{array}{l}\text { Razão do salário feminino médio pelo salário } \\
\text { masculino médio }\end{array}$ \\
\hline \multirow[t]{5}{*}{ Saúde } & Status Nutricional & Status Nutricional das crianças \\
\hline & Mortalidade & Coeficiente de mortalidade até cinco anos de idade \\
\hline & Saneamento & $\begin{array}{l}\text { Expectativa de vida ao nascer } \\
\text { Percentagem da população com dispositivo de esgoto } \\
\text { sanitário }\end{array}$ \\
\hline & Água Potável & $\begin{array}{l}\text { Percentagem da população com acesso a água } \\
\text { tratada }\end{array}$ \\
\hline & $\begin{array}{l}\text { Distribuição da atenção a } \\
\text { Saúde }\end{array}$ & $\begin{array}{l}\text { Percentagem da população com acesso às unidades } \\
\text { de atenção primária a saúde } \\
\text { Imunização contra doenças infecciosas infantis } \\
\text { Coeficiente de prevalência contraceptiva }\end{array}$ \\
\hline \multirow[t]{2}{*}{ Educação } & Nível de educação & $\begin{array}{l}\text { Porcentagem das crianças fora da escola fundamental } \\
\text { com } 5 \text { anos de duração } \\
\text { Nível de educação média (secundária) entre adultos }\end{array}$ \\
\hline & Alfabetização & Taxa de analfabetismo de adultos \\
\hline Moradia & Condições de & Área construída de moradia por pessoa \\
\hline Segurança & Crime & $\begin{array}{l}\text { Número de crimes registrados por grupos de } 100.000 \\
\text { pessoas }\end{array}$ \\
\hline População & Mudanças demográficas & $\begin{array}{l}\text { Taxa de crescimento da população } \\
\text { População urbana em moradias formalmente } \\
\text { regularizadas ou irregulares }\end{array}$ \\
\hline
\end{tabular}

SUSTENTABILIDADE AMBIENTAL

\begin{tabular}{l|l|l}
\hline Tema & Subtema & Indicador \\
\hline Atmosfera & Mudança Climática & Emissão de gases que contribuem para o efeito estufa \\
\hline Terra & Agricultura & $\begin{array}{l}\text { Área de cultura agrícola permanente e de terras } \\
\text { agricultáveis }\end{array}$ \\
\hline
\end{tabular}




\begin{tabular}{|c|c|c|}
\hline & & Uso de fertilizantes e uso de agrotóxico \\
\hline & Florestas & Área permanente de floresta \\
\hline & & Revestimento da mata intensiva \\
\hline & Desertificação & Área Desertificada \\
\hline & Urbanização & Área de Urbanização legal e ilegal \\
\hline \multirow{5}{*}{$\begin{array}{l}\text { Oceanos, } \\
\text { Mares } \\
\text { Costas }\end{array}$} & Zona Costeira & Concentração de algas em águas costeiras \\
\hline & & $\begin{array}{l}\text { Porcentagem da população total vivendo em zonas } \\
\text { costeiras }\end{array}$ \\
\hline & Pesqueiros & $\begin{array}{l}\text { Captura anual de espécies de maior interesse } \\
\text { comercial }\end{array}$ \\
\hline & Quantidade de água & $\begin{array}{l}\text { Porcentagem de fornecimento anual de água } \\
\text { subterrânea e de superfície por disponibilidade total } \\
\text { de água }\end{array}$ \\
\hline & Qualidade da água & $\begin{array}{l}\text { Demanda Bioquímica por Oxigênio (DBO) em corpos } \\
\text { d'agua }\end{array}$ \\
\hline \multirow[t]{3}{*}{ Biodiversidade } & Ecossistemas & Áreas protegidas \\
\hline & & Porcentagem da área protegida por área total \\
\hline & Espécies & Abundância das espécies protegidas \\
\hline \multicolumn{3}{|c|}{ SUSTENTABILIDADE ECONOMICA } \\
\hline \multirow[t]{3}{*}{$\begin{array}{l}\text { Estrutura } \\
\text { Econômica }\end{array}$} & Crescimento econômico & $\begin{array}{l}\text { Produto Nacional Bruto (PNB) per capita } \\
\text { Investimento em ações na forma do PNB }\end{array}$ \\
\hline & Comércio & Balança Comercial \\
\hline & Sistema Financeiro & $\begin{array}{l}\text { Divida Externa pelo PIB } \\
\text { Assistência Financeira prestada ou recebida pelo país } \\
\text { em percentagem do PNB }\end{array}$ \\
\hline \multirow{3}{*}{$\begin{array}{lr}\text { Consumo } & \text { e } \\
\text { padrões } & \text { de } \\
\text { produção } & \end{array}$} & Matérias primas & Intensidade de consumo das matérias primas \\
\hline & Uso de Energia & $\begin{array}{l}\text { Consumo anual per capita de energia } \\
\text { Investimento em ações de energia renováveis e não } \\
\text { renováveis Intensidade do uso da energia }\end{array}$ \\
\hline & Gerenciamento de efluentes & $\begin{array}{l}\text { Gerenciamento do lixo industrial e outros resíduos } \\
\text { urbanos. Geração de lixo perigoso } \\
\text { Geração de lixo radioativo }\end{array}$ \\
\hline
\end{tabular}

Fonte: ONU, 1996.

Somando-se a estes indicadores foi também analisada outra 
metodologia conhecida como Tourism Ecological Footprint Method (TEFM), ou Pegada Ecológica do Turismo, que foi proposta por Gössling et al. (2002) e que permitiu a avaliação dos impactos ambientais do turismo local.

Para essa análise da Pegada Ecológica foram escolhidos, para fins do cálculo da Pegada Ecológica do Turismo na cidade de Mateiros, as seguintes categorias, baseadas no trabalho de Feitosa e Gomez (2012), com exceção da categoria Transporte marítimo, por não se aplicar à região, e acréscimo da categoria Transporte terrestre, por essa sim, se adequar à região pesquisada, conforme pode ser visto na TAB. 4.3:

Tabela 4.3: Procedimentos para cálculo da Pegada Ecológica do Turismo:

\begin{tabular}{|c|c|c|}
\hline $\begin{array}{l}\text { Categoria de } \\
\text { Análise }\end{array}$ & $\begin{array}{l}\text { Tipo de Terra } \\
\text { Associada }\end{array}$ & $\begin{array}{l}\text { Procedimentos para Cálculo da Pegada Ecológica } \\
\text { do Turismo referente à categoria transporte }\end{array}$ \\
\hline \multirow{3}{*}{ TRANSPORTE } & $\begin{array}{l}\text { Terras } \\
\text { Construídas }\end{array}$ & $\begin{array}{l}\text { 1) Estimar o total de turistas de lazer que estiveram no } \\
\text { destino turístico no ano que se optou por realizar a } \\
\text { investigação; } \\
\text { 2) Identificar a área (ha) da infraestrutura de transportes } \\
\text { utilizada pelos turistas (aeroportos, portos, aeródromos, } \\
\text { parques de estacionamento, rodovias, caminhos de } \\
\text { ferro existentes); } \\
\text { 3) Somar todas as áreas para obter a área total da } \\
\text { infraestrutura aeroportuária; e } \\
\text { 4) Dividir a área total pelo número de turistas. }\end{array}$ \\
\hline & \multirow[b]{2}{*}{$\begin{array}{l}\text { Terras de } \\
\text { Energia Fóssil }\end{array}$} & $\begin{array}{l}\text { Para o Transporte Aéreo: } \\
\text { 1) Estimar o total de passageiros por voo com destino } \\
\text { Jalapão; } \\
\text { 2) Estimar a distância percorrida por voo; } \\
\text { 3) Determinar a distância total voada por passageiro- } \\
\text { quilômetro (pkm), multiplicando a distância voada (km) } \\
\text { pelo total de passageiros; } \\
\text { 4) Multiplicar a distância total voada (pkm) pelo fator de } \\
\text { intensidade energética ( } 2 \mathrm{MJ} / \mathrm{pkm} \text { ) para obter o consumo } \\
\text { energético do voo; } \\
\text { 5) Converter para Gigajoule (GJ) o resultado encontrado } \\
\text { no item } 4 \text {, considerando que } 1 \mathrm{GJ}=1.000 \mathrm{MJ} \text {; } \\
\text { 6) Dividir o consumo energético do voo (GJ) pelo total } \\
\text { de passageiros para identificar o consumo energético } \\
\text { per capita; } \\
\text { 7) Dividir o consumo energético per capita (GJ/cap) por } \\
\text { 73 GJ/ha/ano, para determinar a quantidade de terra de } \\
\text { energia fóssil demandada per capita (ha/cap); e } \\
\text { 8) Estimar novamente a terra de energia fóssil requerida } \\
\text { por passageiro, multiplicando-se o resultado do item } 7 \\
\text { pelo fator de correção para grandes altitudes, isto é, } 2,7 \text {. }\end{array}$ \\
\hline & & $\begin{array}{l}\text { Para o Transporte Terrestre (adaptado de acordo com o } \\
\text { trabalho de ANDRADE, 2006): } \\
\text { 1) Estimar o total de turistas que visitam o destino }\end{array}$ \\
\hline
\end{tabular}




\begin{tabular}{|c|c|c|}
\hline & & 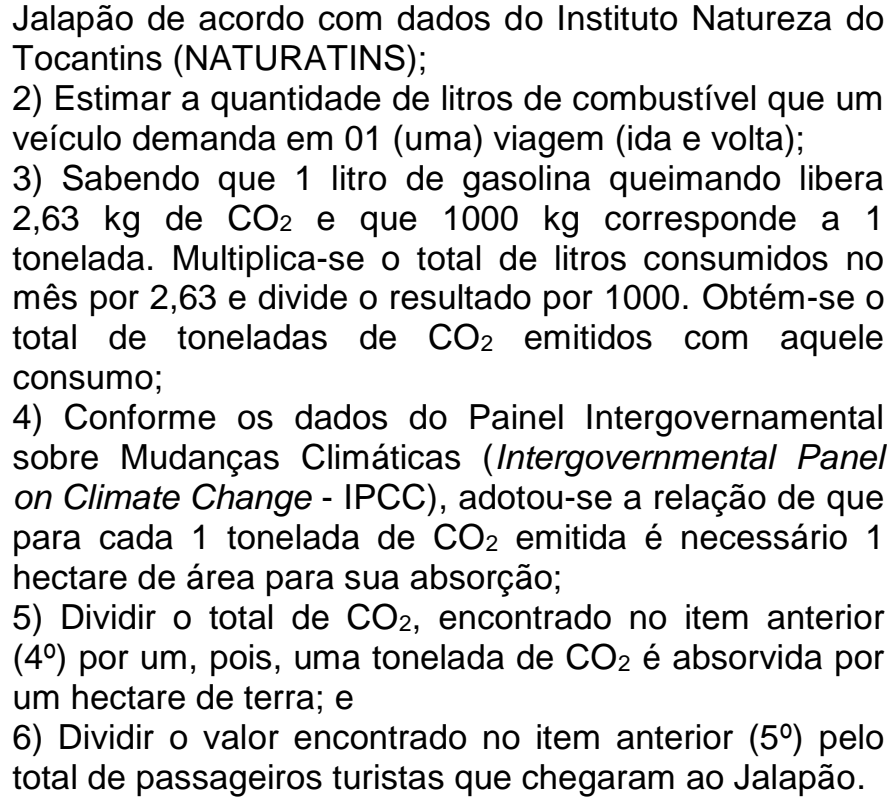 \\
\hline & & 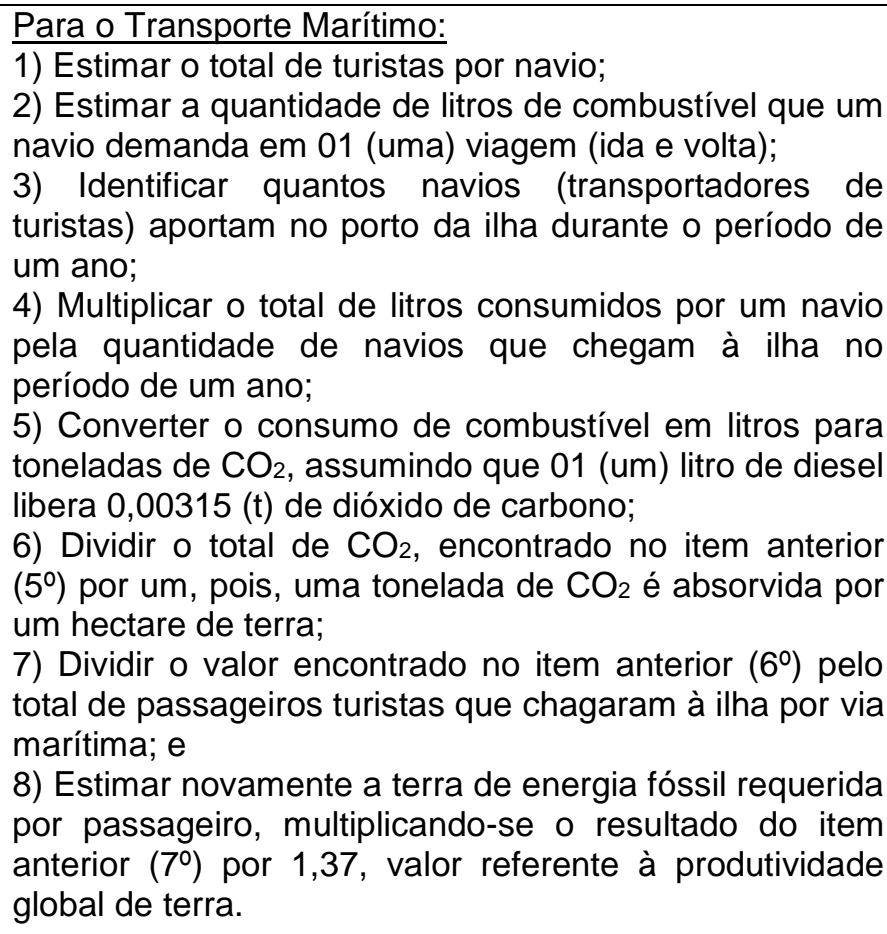 \\
\hline ÁGUA & $\begin{array}{l}\text { Terras de } \\
\text { Energia Fóssil }\end{array}$ & $\begin{array}{l}\text { 1) Estimar o consumo de água em } \mathrm{m}^{3} \text { em } 01 \text { (um) leito } \\
\text { considerando que a média de consumo é de } \\
\text { 120L/hóspede/dia; } \\
\text { 2) Converter para } \mathrm{ML} \text { o resultado do item } 01 \text {, } \\
\text { considerando que } 1 \mathrm{ML} \text { equivale a } 100 \mathrm{~m}^{3} ; \\
\text { 3) Calcular o total de } \mathrm{CO}_{2} \text { emitido, transformando } \mathrm{ML} \\
\text { em toneladas e assumindo que durante o processo de } \\
\text { tratamento, encanação e distribuição são liberados } 0,37 \\
\text { t para cada ML de água; } \\
\text { 4) Estimar o total de leitos da infraestrutura hoteleira } \\
\text { ocupados em um ano; e } \\
\text { 5) Multiplicar o consumo de água em } 1 \text { leito pelo total de } \\
\text { leitos do alojamento. }\end{array}$ \\
\hline & & \\
\hline
\end{tabular}




\begin{tabular}{|c|c|c|}
\hline $\begin{array}{l}\text { RESÍDUOS } \\
\text { SÓLIDOS }\end{array}$ & $\begin{array}{l}\text { Terras de } \\
\text { Energia Fóssil }\end{array}$ & $\begin{array}{l}\text { 1) Estimar o volume de resíduos, em } \mathrm{kg} \text {, produzidos por } \\
\text { um turista em um ano, considerando que uma pessoa, } \\
\text { no Brasil, gera em média } 1,5 \mathrm{~kg} \text { de resíduos sólidos/dia. } \\
\text { 2) Converter para toneladas o resultado do item } 01 \text {, } \\
\text { considerando que } 1 \mathrm{t} \text { equivale a } 1000 \mathrm{~kg} \text {. } \\
\text { 3) Converter as toneladas de resíduos produzidos em } \\
\text { toneladas de } \mathrm{CO}_{2} \text {, admitindo que } 0,00135 \mathrm{t} \text { de resíduos } \\
\text { equivale a } 0,00045 \mathrm{t} \text { de } \mathrm{CO}_{2} \text {; } \\
\text { 4) Multiplicar o valor encontrado no item } 3 \text { por } 2 \text {, pois no } \\
\text { momento em que se produz uma t de } \mathrm{CO}_{2} \text { gera-se } \\
\text { também uma t de } \mathrm{CH}_{4} \text { (gás metano); } \\
\text { 5) Estimar a quantidade turistas que estiveram no } \\
\text { destino no período de um ano; e } \\
\text { 6) Multiplicar o valor encontrado no item } 5 \text { pelo total de } \\
\text { turistas que visitaram o destino no período de um ano. }\end{array}$ \\
\hline \multirow[t]{2}{*}{ ALOJAMENTO } & $\begin{array}{l}\text { Terras } \\
\text { construídas }\end{array}$ & $\begin{array}{l}\text { Estimar a área requerida por leito, considerando que a } \\
\text { quantidade terras construídas demandadas por leito é } \\
\text { de } 60 \mathrm{~m} 2 \text {, em uma posada de luxo } 200 \mathrm{~m}^{2}, 100 \mathrm{~m}^{2} \text { para } \\
\text { hotéis de uma a duas estrelas, } 300 \mathrm{~m}^{2} \text { para hotéis de } \\
\text { três a quatro estrelas, } 2000 \mathrm{~m}^{2} \text { em hotéis de cinco } \\
\text { estrelas, } 300 \mathrm{~m}^{2} \text { para apartamentos, } 50 \mathrm{~m}^{2} \text { para casas } \\
\text { particulares, } 15 \mathrm{~m}^{2} \text { para barcos (já incluindo a área do } \\
\text { porto). } \\
\text { 1) Estimar o total de leitos da infraestrutura hoteleira; e } \\
\text { 2) Multiplicar a área de terra requerida por cada leito } \\
\text { pelo total de leitos que o alojamento possui. }\end{array}$ \\
\hline & $\begin{array}{l}\text { Terras de } \\
\text { Energia Fóssil }\end{array}$ & $\begin{array}{l}\text { Estimar o consumo de energia em } 01 \text { (um) leito } \\
\text { considerando que a média de consumo é de } 50 \\
\text { MJ/leito/noite em alojamentos na zona rural e } 130 \\
\text { MJ/leito/noite nos alojamentos da hotelaria tradicional. } \\
\text { 1) Estimar o consumo de energia elétrica (MWh) pela } \\
\text { atividade turística no período de um ano; } \\
\text { 2) Converter para GJ o resultado do item 1, } \\
\text { considerando que } 1 \mathrm{MWh} \text { equivale a } 3,6 \mathrm{GJ} \text {; } \\
\text { 3) Estimar o total de leitos da infraestrutura hoteleira } \\
\text { ocupados em um ano; e } \\
\text { 4) Multiplicar o consumo de energia em } 1 \text { leito pelo total } \\
\text { de leitos do alojamento. }\end{array}$ \\
\hline $\begin{array}{l}\text { ATIVIDADES } \\
\text { DE LAZER }\end{array}$ & $\begin{array}{l}\text { Terras de } \\
\text { Energia Fóssil }\end{array}$ & $\begin{array}{l}\text { Para efeito do cálculo da pegada para a categoria } \\
\text { atividades, Gössling et al. (2002) levaram em } \\
\text { consideração apenas as áreas relativas aos campos de } \\
\text { golfe. Assim, adaptou-se aqui para área construídas em } \\
\text { atrativos turísticos mais visitados: } \\
\text { 1) Estimar o total de turistas de lazer que estiveram no } \\
\text { destino turístico no ano em que optou-se realizar a } \\
\text { investigação; } \\
\text { 2) Estimar a área total (ha) referente ao somatório de } \\
\text { áreas construídas nos atrativos turísticos do destino; e } \\
\text { 3) Dividir a área total ocupada pelos atrativos pela } \\
\text { quantidade de turistas que estiveram no Jalapão }\end{array}$ \\
\hline $\begin{array}{l}\text { ALIMENTAÇÃO } \\
\text { E CONSUMO } \\
\text { DE FIBRAS }\end{array}$ & $\begin{array}{l}\text { Terras } \\
\text { bioprodutivas }\end{array}$ & $\begin{array}{l}\text { Para o cálculo da categoria alimentação e consumo de } \\
\text { fibras, Gössling et al. (2002) consideraram que os } \\
\text { turistas em um destino turístico consomem os mesmos } \\
\text { tipos de alimentos e fibras disponíveis no país de } \\
\text { origem. } \\
\text { Dessa forma: } \\
\text { 1) Identificar a nacionalidade dos turistas que visitam o } \\
\text { destino que se deseja investigar; } \\
\text { 2) Identificar o consumo de alimentação e fibras dos }\end{array}$ \\
\hline
\end{tabular}




\begin{tabular}{l|l}
\hline & turistas em seus 10 locais de origem no período de um \\
& ano; \\
& 3) Fazer o somatório de todos os valores de consumo \\
& de alimentos e fibras encontrados no período de um \\
& ano; \\
& 4) Calcular a média de consumo dos turistas em um \\
& ano; \\
& 5) Dividir o valor encontrado no item 4 por 365 ou 366 \\
& (ano bissexto); e \\
& 6) Multiplicar o valor encontrado no item 5 pela estadia \\
& média do turista no destino. \\
\hline
\end{tabular}

Fonte: FEITOSA e GOMES (2012)

Ainda de acordo com os autores para se calcular a Pegada Ecológica se faz necessário alguns outros cálculos:

Cálculo da Pegada Ecológica de Terras de Energia Fóssil = Terra de energia fóssil dos transportes + Terra de Energia Fóssil das Acomodações + Terra de Energia Fóssil da Água + Terra de Energia Fóssil dos Resíduos Sólidos.

Cálculo da Pegada Ecológica de Terras Construídas = Área de Terra Construída Pelos Aeroportos + Área de Terra Construída Pelas Acomodações + Área de Terra Construída Pelos atrativos.

Cálculo da Pegada Ecológica de Terras Bioprodutivas $=\mu$ do consumo de alimentos e fibras dos turistas*.

* A média anual de consumo de cada indivíduo está disponível no relatório planeta vivo (WWF, 2016)

Pegada Ecológica do Turismo $=$ Pegada Ecológica de Terras de Energia Fóssil $\times 1,8+$ Pegada Ecológica de Terras Construídas × 3,2 + Pegada Ecológica de Terras

Bioprodutivas*

* já estão inseridos os fatores de equivalência.

Saldo Ecológico do Turismo (ha) = Pegada Ecológica do Turismo (ha) - Biocapacidade do Território (ha)*

*Soma de todas as áreas bioprodutivas do destino turístico

Déficit ecológico $=$ Pegada Ecológica $>$ Biocapacidade

Superávit ecológico $=$ Pegada Ecológica $<$ Biocapacidade

Para auxiliar o trabalho também foram exploradas as narrativas orais, que de acordo com Portelli (2001), viabilizam o conhecimento das atividades econômicas da comunidade na atualidade e quais as influências e modificações identificadas ao longo do tempo. Permite também ampliar os conhecimentos e as informações sobre um passado recente por meio da 
versão das pessoas que o viveram (PARENTE, 2006). Tais narrativas permitiram, ainda, a compreensão da percepção e perspectivas da população com relação ao nível de desenvolvimento, conservação ambiental e qualidade de vida da comunidade.

\section{4 - Interpretação dos dados}

Para atender aos objetivos do estudo, além de técnicas básicas de análise exploratória como análise de frequências e mediana, foram utilizadas outras três metodologias: o Teste de Wilcoxon para amostras pareadas, o teste de Mann-Whitney para duas amostras independentes e o teste de KruskalWallis para $\mathrm{k}$ amostras independentes (LEHMANN, 1975).

Para avaliar a consistência do instrumento Mini-Cex foi aplicado o alpha de Cronbach no conjunto de questões de avaliação referentes a cada um dos indicadores 1 a 8 e o questionário com um todo.

Todos os testes de hipóteses desenvolvidos nesse trabalho consideraram uma significância de $5 \%$, ou seja, a hipótese nula foi rejeitada quando $p$-valor foi menor ou igual a 0,05 .

\subsection{1 - Teste de Wilcoxon para dados pareados}

Seja $\mu$ o valor de interesse, então se xi $>\mu$, ao par é atribuído um sinal positivo $(+)$ e se $x i<\mu$, ele recebe um sinal negativo $(-)$, onde $x_{i}$ é o valor da resposta para a i-ésima observação.

Seja $S$ a quantidade de sinais + na amostra. Sob a hipótese nula é esperado ter um número aproximadamente igual de sinais $+\mathrm{e}-$. Equivalentemente, a probabilidade de que uma diferença seja positiva é $1 / 2$ e a probabilidade de que seja negativa é também $1 / 2(S \sim$ binomial $(n ; 0,5))$.

Para avaliar se existe diferença entre dois momentos, basta criar uma variável de diferença e verificar se o número de valores positivos difere do número de valores negativos, ou seja, $\mu_{0}=0$. 
O teste do sinal não faz suposição sobre a distribuição da resposta. A hipótese a ser testada é:

$H_{0}$ : \# de observações acima de 0 é igual ao \# de observações abaixo de 0

Onde rejeitar $\mathrm{H}_{0}$ significa que $\mu_{0}$ é diferente de zero.

\subsection{2 - Teste de Mann-Withney para 2 amostras independentes}

O teste de Mann-Whitney é um teste não-paramétrico alternativo ao teste t-Student para comparar as médias de duas amostras independentes.

A única suposição necessária para a aplicação desse teste é que as duas amostras sejam independentes e aleatórias, e que as variáveis em análise sejam numéricas, contínuas ou ordinais.

O teste estatístico é calculado combinando as observações das duas amostras em uma única variável de tamanho $\mathrm{N} 1+\mathrm{N} 2$, sendo identificadas as respectivas amostras. Feito isso, essa variável é ordenada (ordem crescente) e é atribuído o posto 1 à primeira observação, 2 à segunda, e assim por diante. No caso de empates, é atribuído o posto médio que essas observações teriam se não fossem empates. Em seguida, calcula-se a soma dos postos das observações de cada amostra (W1 e W2). São calculadas as quantidades:

$$
\begin{aligned}
& U_{1}=N_{1} N_{2}+\frac{N_{2}\left(N_{2}+1\right)}{2}-W_{2} \\
& U_{2}=N_{1} N_{2}+\frac{N_{1}\left(N_{1}+1\right)}{2}-W_{1}
\end{aligned}
$$

A estatística teste é:

$$
U=\min \left(U_{1}, U_{2}\right)
$$


E a hipótese a ser testada é:

HO: as distribuições das duas amostras são iguais

Onde rejeitar $\mathrm{HO}$ significa que as duas amostras apresentam distribuições significativamente distintas.

\subsection{3 - Teste de Kruskal-Wallis para $\mathbf{k}$ amostras independentes}

O teste Kruskal-Wallis é um teste não paramétrico que equivale ao teste F da ANOVA, ou seja, o teste de Kruskal-Wallis tem como objetivo detectar se existe diferença significativa entre as médias (parâmetro de localização das distribuições) de $\mathrm{k}$ amostras diferentes. Este teste não paramétrico tem a vantagem, perante o teste $\mathrm{F}$ da ANOVA, o fato de não supor normalidade na distribuição da variável de interesse nem homoscedasticidade (igualdade de variância das $\mathrm{k}$ diferentes populações) dependendo apenas que a variável seja de escala ordinal.

O teste Kruskal-Wallis é baseado na estatística de postos, em que se utilizou os números de ordem das observações para obter a estatística do teste. Primeiramente juntam-se as observações de todos os grupos que se quer comparar ( $k$ amostras), e ordenam-se todas as observações de forma crescente, o número de ordem de cada observação é seu posto. Quando existem observações iguais (empates), o número de ordem a atribuir a cada uma das observações empatadas é o número de ordem médio dos números de ordem que essas observações teriam se não estivessem empatadas.

Sejam $\mathrm{k}$ as amostras em análise, cada um com Ni repetições, Pretendese verificar se as $\mathrm{k}$ amostras têm distribuições idênticas. $\mathrm{O}$ teste de hipóteses é:

HO: As distribuições das k amostras são idênticas;

H1: As distribuições das $k$ amostras diferem na localização. 
A estatística de teste é:

$$
\mathrm{H}=\frac{12}{\mathrm{~N} \cdot(\mathrm{N}+1)} \sum_{\mathrm{t}=1}^{\mathrm{k}} \frac{\mathrm{R}_{\mathrm{i}}^{2}}{\mathrm{~N}_{\mathrm{i}}}-3 .(\mathrm{N}+1)
$$

onde Ri é a soma dos números de ordem das Ni observações do grupo i.

Se existem números de ordem empatados, a estatística de teste deve ser corrigida para:

$$
C=1-\frac{\sum_{t=1}^{m}\left(u_{t}^{3}-u\right)}{N^{3}-N}
$$

Em que ut é o número de empates em cada grupo e m é o número de grupos de ordem empatados.

\subsection{3 - Alpha de Cronbach}

O Alfa de Cronbach, apresentado por Lee J. Cronbach em 1951, é uma forma de estimar a confiabilidade de um questionário aplicado em uma pesquisa. Esse coeficiente mede a correlação entre respostas em um questionário através da análise das respostas dadas pelos respondentes, apresentando uma correlação média entre as perguntas. O coeficiente a é dado por: 


$$
\propto=\frac{K}{K-1}\left[1-\frac{\sum V_{i}}{V_{t}}\right]
$$

Onde $\mathrm{K}$ é o número de itens, $\mathrm{V}_{\mathrm{i}}$ é a variância de cada item e $\mathrm{V}_{t}$ é a variância total.

Valores de Alpha de Cronbach maiores que 0,6 indicam que 0 instrumento é confiável e produz mensurações estáveis e consistentes [1]. Valores menores que 0,6 indicam que o instrumento pode apresentar uma variabilidade heterogênea entre seus itens e, portanto, poderá levar a conclusões equivocadas [1]. 


\section{5 - RESULTADOS E DISCUSSÕES}

Neste capítulo são apresentados e discutidos os principais resultados da pesquisa com a cidade de Mateiros/TO. Os resultados foram divididos de acordo com as etapas da pesquisa. Desta forma, são apresentados inicialmente os resultados dos indicadores da ONU.

Em seguida são apresentados os Índices de Qualidade de Vida coletados e na sequência, a Pegada Ecológica do Turismo. Por fim, é apresentada a comparação das metodologias utilizadas na pesquisa.

\section{1 - Análise dos Indicadores da Organização das Nações Unidas.}

Nesse método de análise foram realizadas entrevistas com o prefeito e a Secretária de Administração, Planejamento e Infraestrutura da cidade, bem como com a Secretária do Meio Ambiente e a Secretária da Saúde do município.

Os resultados foram publicados na Revista "International Journal of Social, Behavioral, Educational, Economic and Management Engineering" (MESSETTI, 2015) e serão apresentados a seguir.

De acordo com os dados coletados por entrevista com a primeira-dama da cidade (FIG. 5.1) a população local tem uma expectativa de vida de 65 anos, sendo, segundo o Instituto Brasileiro de Geografia e Estatística (IBGE, 2015), abaixo da média do estado que é 72 anos. Não foram localizados estudos que determinassem a porcentagem da população da localidade vivendo abaixo da linha da pobreza, ou a diferença do salário médio entre sexos masculino e feminino, desemprego, condição nutricional das crianças, uso de métodos contraceptivos entre as mulheres, moradias urbanas regulares e irregulares e o número de residências habitadas na região. Nem mesmo há controle pela prefeitura da cidade para fins de cobrança de impostos, pois 
segundo a gestora local, há um abandono frequente de casas na cidade na medida em que a população migra para novas áreas dentro do município.

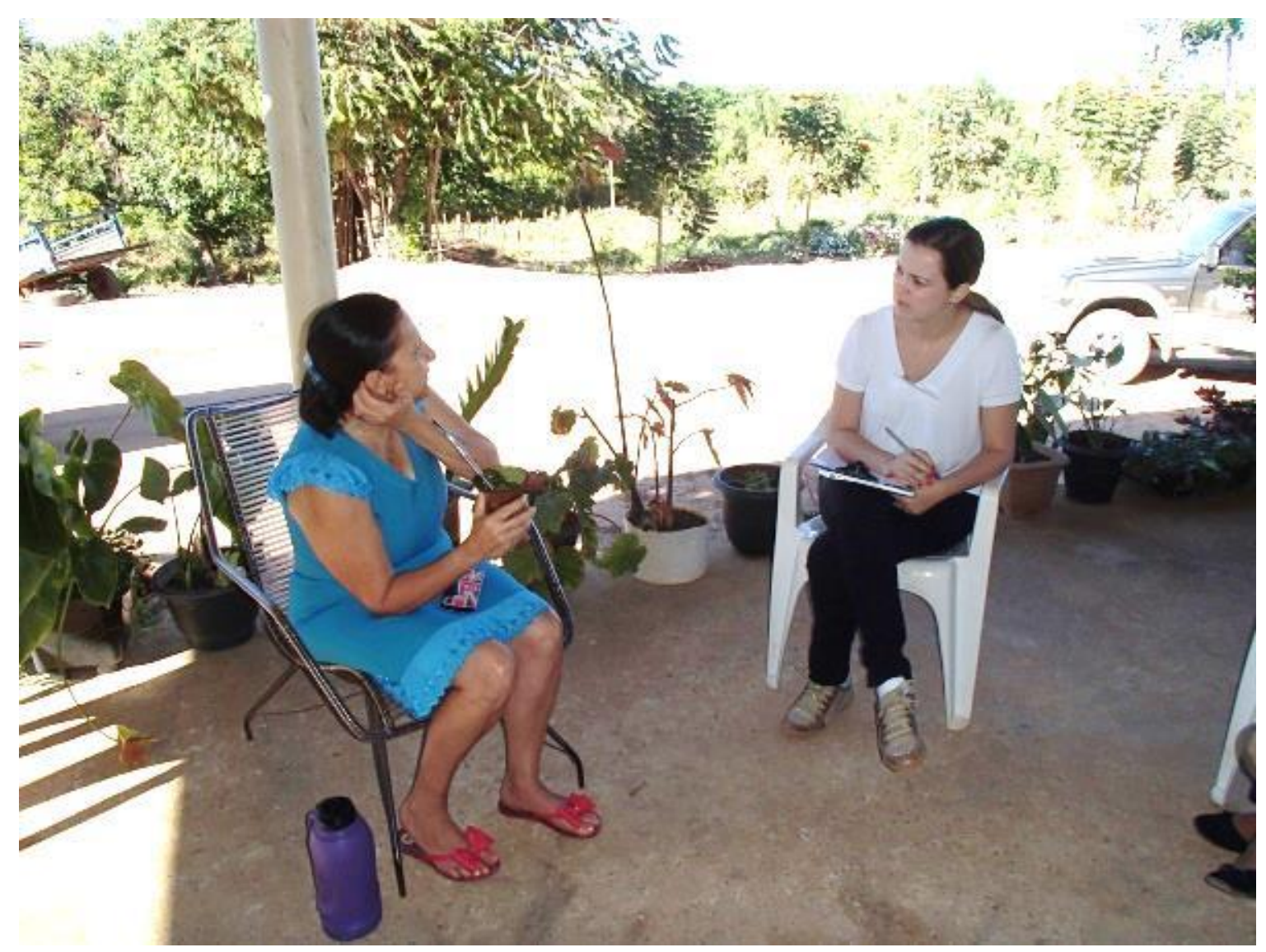

Figura 5.1 - Entrevista com a Secretária de Administração, Planejamento e Infraestrutura de Mateiros.

De acordo com a entrevista com a Secretária de Saúde do município, o coeficiente de mortalidade anual de crianças até cinco (5) anos é de $0,01 \%$. A rede de saúde conta com 40 atendimentos diários entre consultas, agendamentos e demandas espontâneas e um total de $80 \%$ das crianças imunizadas anualmente contra doenças infecciosas infantis entre os anos de 2012 a 2014. Dois por cento das crianças estão fora da escola fundamental, enquanto apenas $7 \%$ dos jovens são atendidos na educação média. A taxa de analfabetismo entre os adultos é de $42 \%$. A média de filhos por família é quatro (4) e segundo IBGE no censo de 2010, o crescimento populacional da cidade de Mateiros foi de $3,05 \%$. Apesar de possuir delegacia, nenhum crime foi 
registrado nos anos de 2014 e 2015. O município também não apresenta sistema de esgoto em funcionamento e nem estação de tratamento de água.

No quesito ambiental, de acordo com a Secretária de Meio Ambiente, muitos aspectos não foram sistematizados por meio de pesquisas, tais como a quantidade emitida de gases que contribuem para o efeito estufa, quantidade de fertilizantes e agrotóxicos usados pelas grandes fazendas na região, área protegida de cerrado na região, incluindo o PEJ, concentração de algas, porcentagem da população vivendo em zonas ribeirinhas, captura anual de espécies de maior interesse comercial, estudos sobre a água utilizada pela população e sua quantidade e abundância de espécies encontradas nas regiões protegidas.

Na região, cerca de 60 mil hectares são cultivados com soja, milho, algodão e outras culturas, porém não se tem dados sobre a cultura de subsistência. A área de desertificação, que está nas Dunas do Jalapão, compreende 1.000 ha.

De acordo com a Secretaria de Meio Ambiente não se tem área de urbanização irregular na região. As áreas protegidas na região englobam o Parque Estadual do Jalapão, APA do Jalapão, Estação Ecológica Serra Geral do Tocantins e o Parque Nacional Nascentes do Rio Parnaíba. O município tem uma área protegida de $86 \%$ e os atrativos que se encontram dentro da área do Parque são: as Dunas, Mirante, Cachoeira do Formiga, Fervedouro do Ceiça, Buritizinho, do Korubo e Rio Sono, Encontro das Águas, Recanto do Salto e a comunidade Mumbuca, sendo que apenas as Dunas e o Mirante não são administrados pelos proprietários e sim pelo órgão regulador da área ambiental do estado do Tocantins, o Instituto Natureza do Tocantins (NATURATINS).

Pela falta de pesquisas científicas na região, não há dados econômicos relacionados aos indicadores das Nações Unidas. Por este motivo, foram utilizados dados secundários para retratar a condição econômica da localidade.

De acordo com a Secretaria de Comunicação Social (SECOM, 2015) do estado do Tocantins, o ecoturismo e a agricultura foram responsáveis pelo aumento de $848 \%$ na renda média dos habitantes da cidade de Mateiros entre 2000 e 2010 , elevando de $R \$ 117,00$ para $R \$ 1.110,00$ por mês. Esses 
números são corroborados com o Índice de Desenvolvimento Humano Municipal (IDHM) do IBGE (2010), que em 2000 era de apenas 0,281 e em 2010 passou para 0,607 . O PIB agropecuário é $R \$ 61,227$ milhões, o industrial é $R \$ 1,622$ milhões e o de serviços é de $R \$ 20,239$ milhões de acordo com dados de 2009 do IBGE.

Apesar da riqueza de paisagens e atrativos turísticos, e ainda da diversidade ambiental de plantas e animais, a cidade de Mateiros ainda apresenta muitas dificuldades em relação aos três pilares do desenvolvimento sustentável (social, econômico e ambiental). A falta de dados faz com que se percam investimentos importantes para a melhoria da qualidade de vida da população, o que, indiretamente, também afeta os turistas. $O$ acesso a esse tipo de informação facilitaria a classificação das áreas, e os investimentos poderiam ser direcionados para as consideradas prioritárias, além de possibilitar políticas locais.

Isso demonstra que o Jalapão ainda deve ser objeto de estudo em várias áreas distintas, pois com a escassez de dados percebidas na área, acredita-se que muitos estudos poderão ser propostos para que a região possa se desenvolver e ser conhecida.

Embora acredite-se que essa ferramenta da ONU, da forma que foi utilizada neste trabalho, não deva ser utilizada em destinos de pequeno porte que se assemelhem à cidade de Mateiros, aonde não há sistematização de dados suficientes para que a ferramenta proposta pela ONU. Apesar disso, ainda acredita-se que ela possa ser utilizada pelos órgãos governamentais na captação de recursos e utilização destes para criar novas políticas públicas para a região. O presente estudo propôs análise de dados secundários e por meio de entrevistas com gestores locais e estaduais sobre os pilares de sustentabilidade local, para que eles possam complementar a pesquisa sobre a qualidade de vida da população e a pegada ecológica do turismo. Dessa forma, poderão ser aproveitados na análise dos dados dos demais métodos de pesquisa propostos neste trabalho. 


\section{2 - Índice de Qualidade de Vida}

Para esse método de pesquisa foi utilizado um questionário padrão (Apêndice D) aplicado em forma de entrevista individual com os moradores locais, conforme FIG. 5.2.

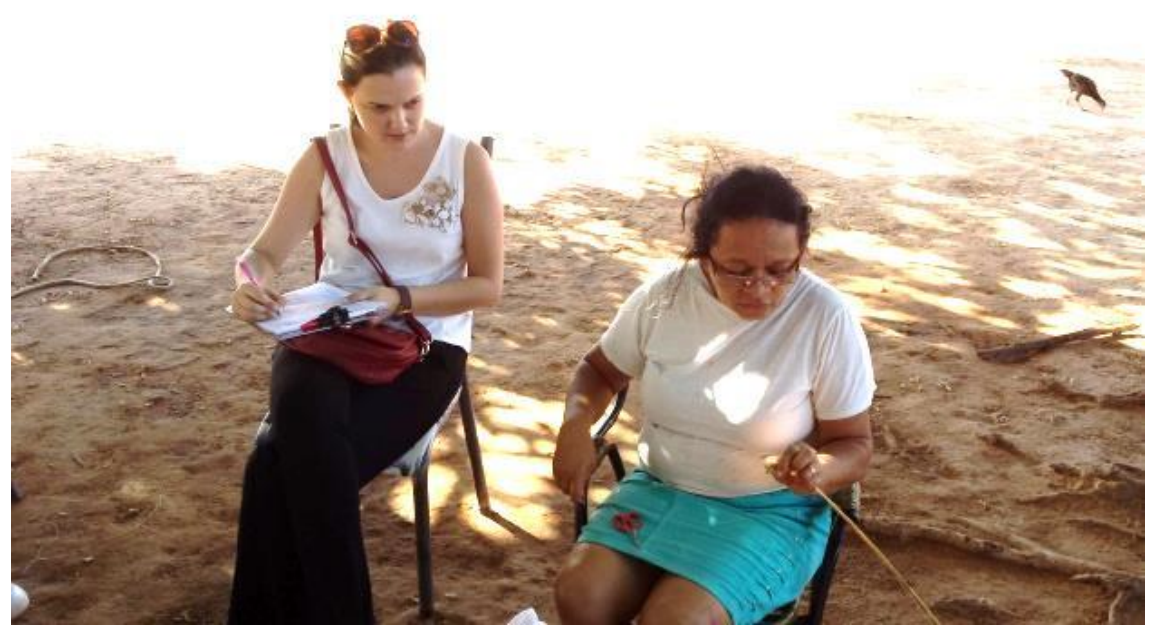

Figura 5.2: Entrevista com artesã de Mateiros

A todos os entrevistados foi pedido que respondessem às questões, independente dele afirmar que atuava ou não com turismo, bem como, colocando-se o ano de 2000 como marco central do surgimento do turismo na região. Dessa forma, mesmo aos que não atuavam com a atividade de turismo foi pedido que respondessem as perguntas do antes e depois, tendo como parâmetro o ano em questão. Isso foi feito para que fosse avaliado se, mesmo que ele não trabalhasse com turismo diretamente houve alguma modificação em sua qualidade de vida após o ano de 2000.

O método das narrativas orais é apresentado por meio de relatos espontâneos durante o processo da entrevista. 


\subsection{1 - Teste Alpha de Cronbach}

O Alpha de Cronbach foi feito separadamente para a amostra antes e depois. Como o objetivo é avaliar o instrumento, o momento mais adequado para a análise é o momento antes do surgimento das atividades turísticas no local (TAB. 5.1).

Tabela 5.1: Alpha de Cronbach por indicador considerando separadamente os dois momentos de pesquisa

\begin{tabular}{cccc} 
Indicador & Antes & Depois & $\begin{array}{c}\text { Antes + } \\
\text { depois }\end{array}$ \\
\hline Indicador 1 & 0,53 & 0,35 & 0,61 \\
Indicador 2 & 0,75 & 0,48 & 0,77 \\
Indicador 3 & 0,54 & 0,16 & 0,51 \\
Indicador 4 & $-0,10$ & $-0,13$ & 0,26 \\
Indicador 5 & 0,55 & 0,50 & 0,60 \\
Indicador 6 & - & - & - \\
Indicador 7 & - & - & - \\
Indicador 8 & 0,27 & - & - \\
\hline Geral & 0,81 & 0,51 & 0,81
\end{tabular}

Observamos que o instrumento como um todo é consistente uma vez que o valor de alpha de Cronbach foi 0.81 .

\subsubsection{Perfil do entrevistado}

Para a caracterização do perfil do entrevistado foram realizadas 10 perguntas que não entraram nos cálculos do IQV. A seguir os resultados sobre o perfil dos entrevistados.

No total de respondentes, $48 \%$ das pessoas declara-se como atuantes em atividades ligadas ao turismo na região de Mateiros (FIG. 5.3). Desse total $70 \%$ tinham 4 ou 5 pessoas que trabalhavam com atividades ligadas ao turismo, como pode ser notado no FIG. 5.4. Como em Mateiros há muitos 
artesãos de capim dourado, atribui-se a isso esse número elevado de pessoas de uma mesma família que atuam na área. Como pode se notar no FIG. 5.5, quase metade dos entrevistados que disseram trabalhar na área iniciaram suas atividades nos anos subsequentes ao turismo, demonstrando assim que o surgimento da atividade acarretou mudanças na economia local. Além disso, uma parcela expressiva mostrou que não trabalhava antes do turismo surgir na região (FIG. 5.6).

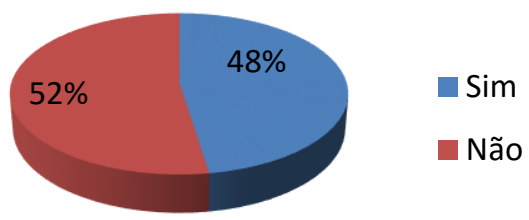

Figura 5.3 - Atuantes e não atuantes com atividades ligadas ao turismo.

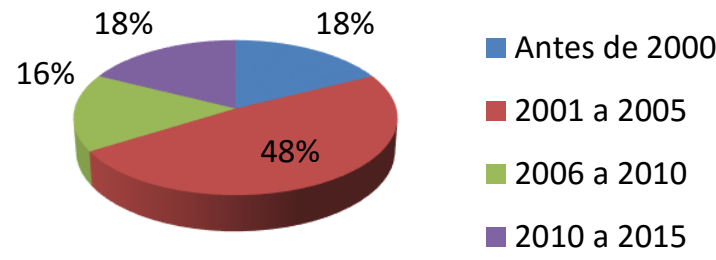

Figura 5.5 - Em que ano o entrevistado começou a trabalhar na atividade

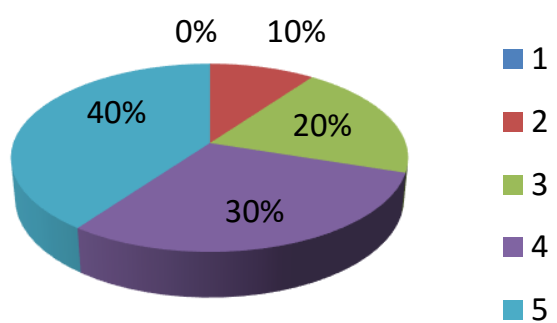

Figura 5.4 - Número de pessoas na casa que atuam com atividades ligadas ao turismo

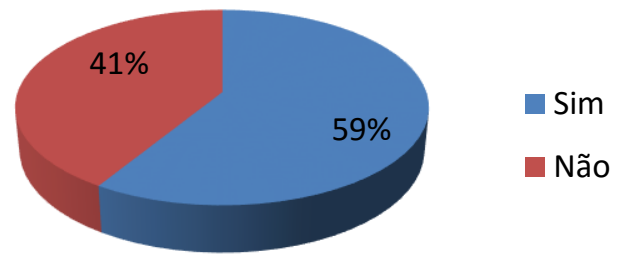

Figura 5.6- Já trabalhava antes de atuar com turismo

A grande maioria dos entrevistados (86\%) reside na zona urbana de Mateiros e demais entrevistados residem em povoados ou regiões isoladas na zona rural. Os entrevistados foram em sua maioria mulheres (67\%). Na grande maioria das residências em que foram realizadas as entrevistas havia a presença de mulheres e homens, mas entre eles quase sempre havia a decisão de a mulher ser a entrevistada. No que tange à idade dos 
entrevistados, mais da metade deles (51\%) estavam na faixa etária de 26 a 45 anos de idade, conforme pode se notar na FIG. 5.7.

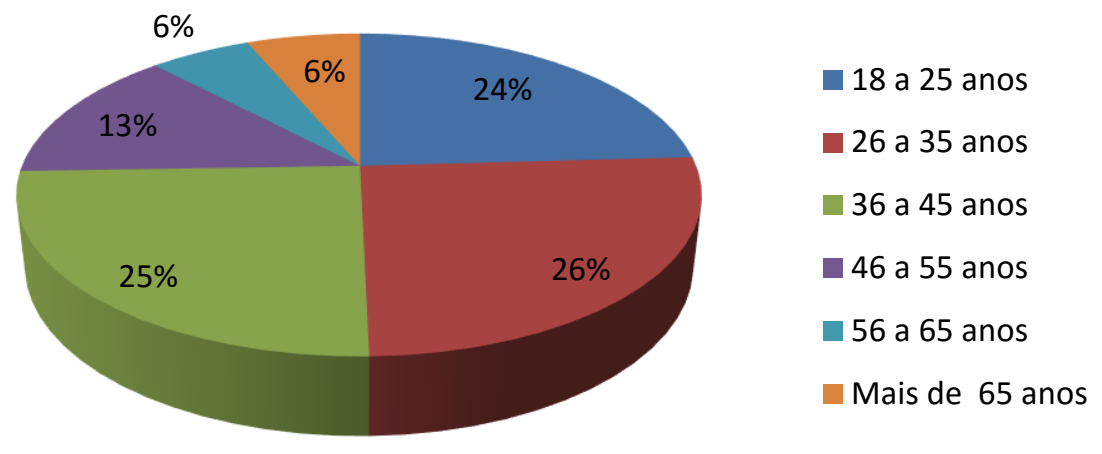

Figura 5.7 - Idade do entrevistado

Foi perguntado também qual era o estado civil antes e depois do surgimento do turismo. As respostas para esse item são apresentadas no FIG. 5.8 e pode se perceber que houve um aumento do número de casamentos e uniões consensuais após o ano de 2000. Isso pode indicar que houve um crescimento no número de famílias constituídas na região, em virtude do progresso na condição econômica de uma cidade que vivia basicamente de agricultura de subsistência na época e que se viu na expectativa da inserção de uma nova forma de atividade que foi o turismo, aumentando assim a renda das famílias.

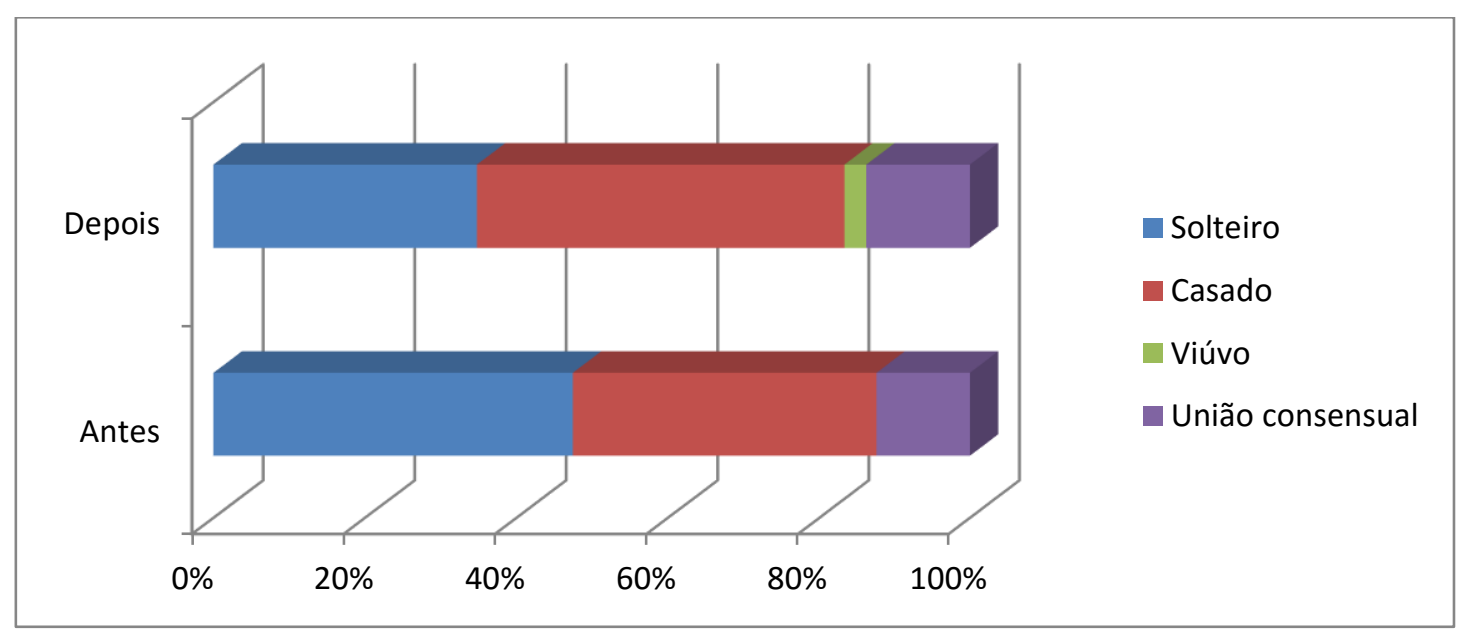

Figura 5.8- Estado Civil antes e depois do turismo 
Quando perguntados se tinham filhos, a grande parcela respondeu que sim (86\%). Quase a metade (49\%) dos respondentes disseram que moravam de 4 a 7 pessoas na casa (FIG. 5.9), mas quase o mesmo percentual (41\%) disseram que moravam apenas 1 a 3 pessoas, o que mostra que não há um número elevado residindo nas mesmas residências. Há de se discutir que a grande maioria das casas é pequena que em média possuem apenas dois quartos. A essa análise acrescenta-se o número de filhos por família sendo que do total de respostas, $71 \%$ afirmaram possuir de 1 a 3 filhos, um número também considerado baixo haja vista as condições socioeconômicas da região (FIG. 5.10).

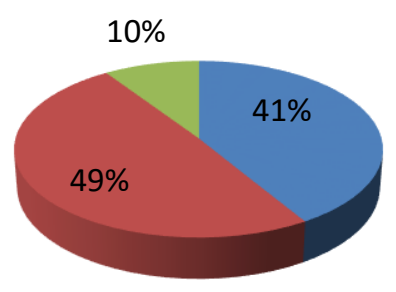

Figura 5.9 - Quantas pessoas moram em sua residência?

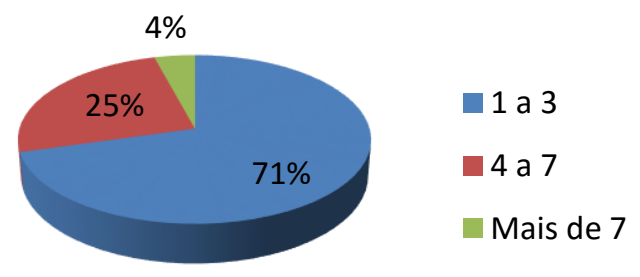

Figura 5.10 - Quantos filhos você tem?

\subsection{2 - Condições de moradia}

Dando início à análise que faz parte do Índice de Qualidade de Vida, um dos indicadores que o compõe diz respeito às condições de moradia, mais especificamente, a condição de posse da moradia. Todas as variáveis apresentam em seu formato uma evolução na condição do morador local. Dessa forma, por exemplo, considera-se que se uma pessoa passa da condição de residência alugada para uma residência cedida, ela deixou de ter um gasto mensal com aluguel e poderia investir esse dinheiro em outras ações que possam propiciar avanço em sua condição de moradia. E por consequência, se ela passa de umas das condições anteriores para residir em 
sua casa própria também houve avanço em sua qualidade de vida. Isso vai se aplicar a todos as variáveis apresentadas nesse trabalho.

A FIG. 5.11 mostra que houve um avanço na condição de posse da residência, pois houve uma redução nas respostas de moradores que necessitam pagar aluguel antes e depois do turismo e ao mesmo tempo houve um aumento no número de respondentes que disseram que conseguiram comprar suas residências. Mesmo os moradores que não dependem diretamente das atividades turísticas, atribuem ao turismo o avanço em todas as condições de vida. As narrativas orais mostram relatos como o entrevistado 1 que diz: "O turismo nos beneficia indiretamente, pois até a prefeitura precisou criar novas vagas para atender às demandas que surgiram depois do desenvolvimento do turismo na região". Na maioria absoluta, apareceram relatos dessa natureza. A comunidade percebe a importância do turismo para a localidade e sabe que muitos na cidade dependem dessa atividade.

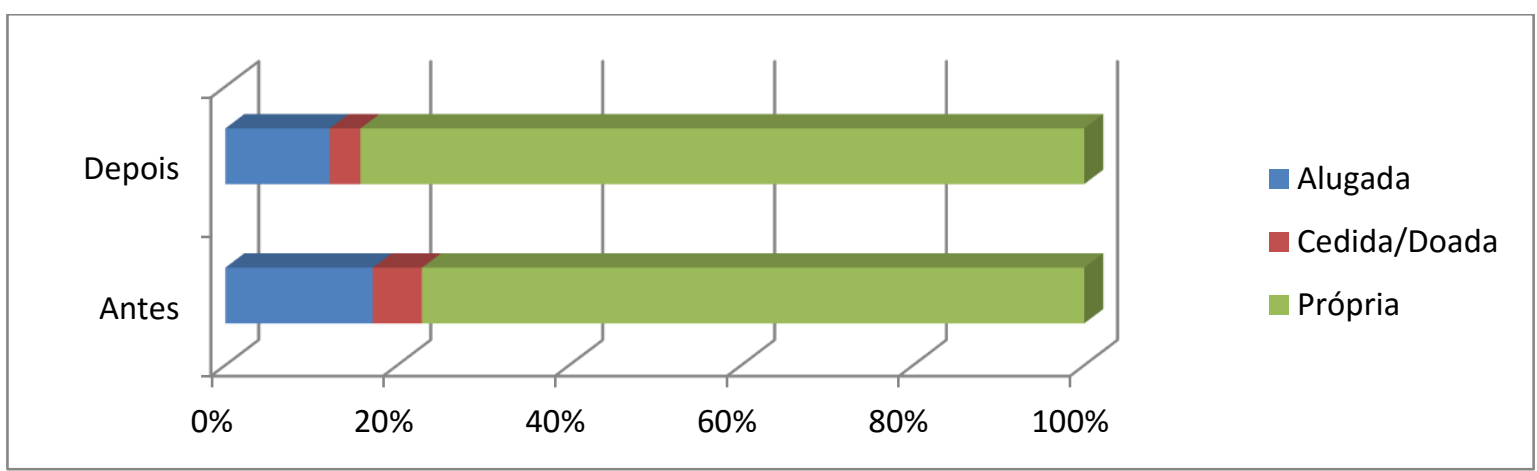

Figura 5.11 - Situação de posse de sua moradia

Os resultados não se mostraram diferentes no que tange ao tipo de construção do domicílio (FIG. 5.12). Houve um decréscimo no número de casas construídas de taipa (construção com terra crua), um aumento nos número de casas construídas de tijolo e com tijolos e reboco. Souza et al. (2015) afirmam que casas construídas de taipas são tidas como residências ultrapassadas e algumas relacionadas à pobreza e doenças de chagas, uma vez que houve uma proliferação desta pelo fato de o vetor da doença (barbeiro) ser atraído por construções dessa natureza. Os mesmos autores afirmam que há estudos que comprovam que o barbeiro adentra essas residências devido à 
expulsão da sua fonte de alimento que é o sangue dos tatus, que se afastam dessas regiões devido ao desmatamento. Os autores defendem o uso desse tipo de construção com terra por possuírem características que compreendem as condições de sustentabilidade, com custo de montagem e manutenção baixo, permitindo o seu consumo pela população local, sem a exigência de logística de transporte, com uso de materiais reciclados. Pelos parâmetros sociais, esses dados indicam o avanço nas condições habitacionais dos moradores de Mateiros, mas ao mesmo tempo, do ponto de vista ambiental, essa evolução nas construções de tijolo e reboco são tidas como não sustentáveis. Para fins de cálculo do IQV, será feita a análise do ponto de vista social dos moradores.

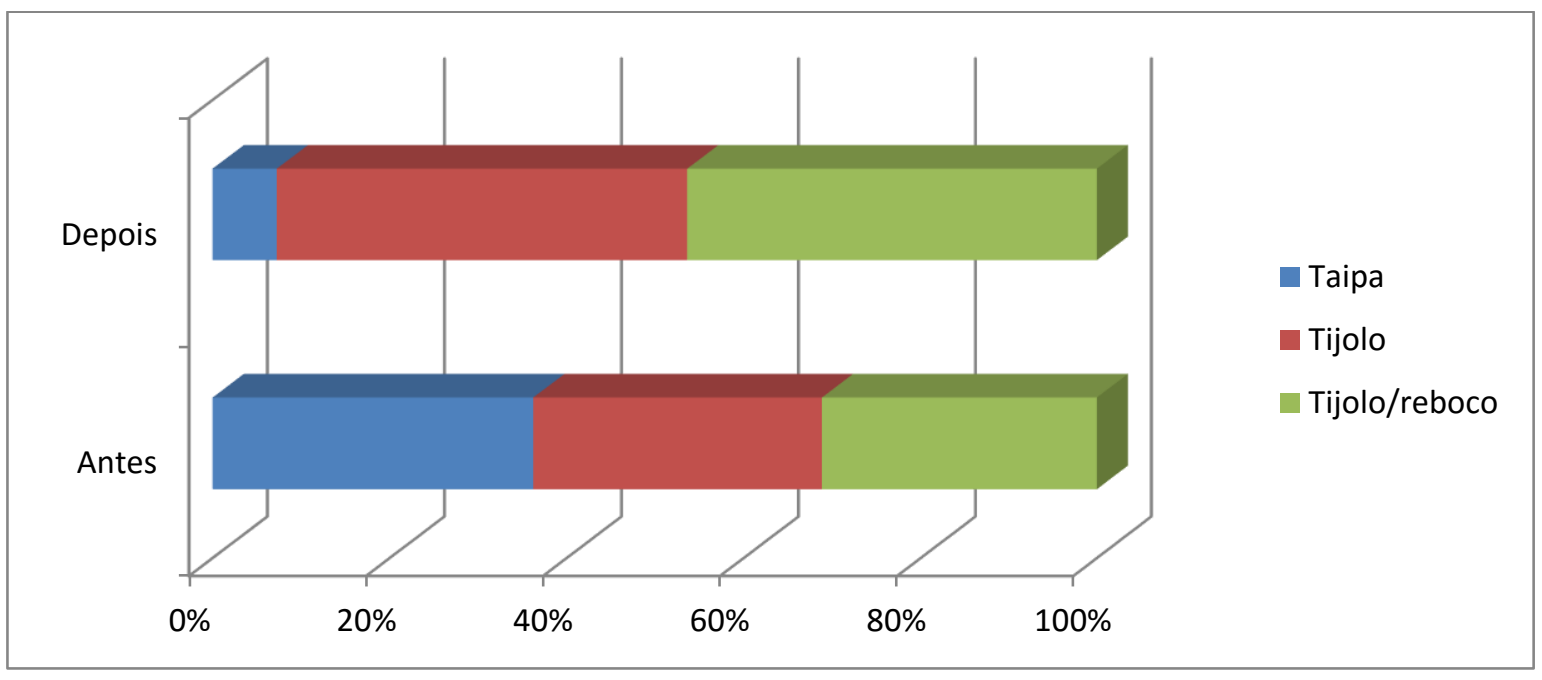

Figura 5.12 - Tipo de construção do domicílio

Da mesma forma, os dados se apresentaram parecidos na comparação do antes e depois do turismo no aspecto do tipo de piso do domicílio (FIG. 5.13). A maioria das casas era de terra compactada, que aparecia nos relatos dos moradores a todo tempo como "chão batido". Houve um decréscimo no número de habitações dos que vivem atualmente em residências sem pisos de cimento ou cerâmica, ao mesmo tempo em que houve um acréscimo no número de famílias que habitam residências já com essas estruturas. No aspecto de conforto térmico, há estudos (LIMA e RIBEIRO, 2009) que indicam que os pisos de cerâmica podem contribuir para o conforto térmico, diminuindo 
a temperatura das residências, aspecto esse de extrema importância para a localidade estudada.

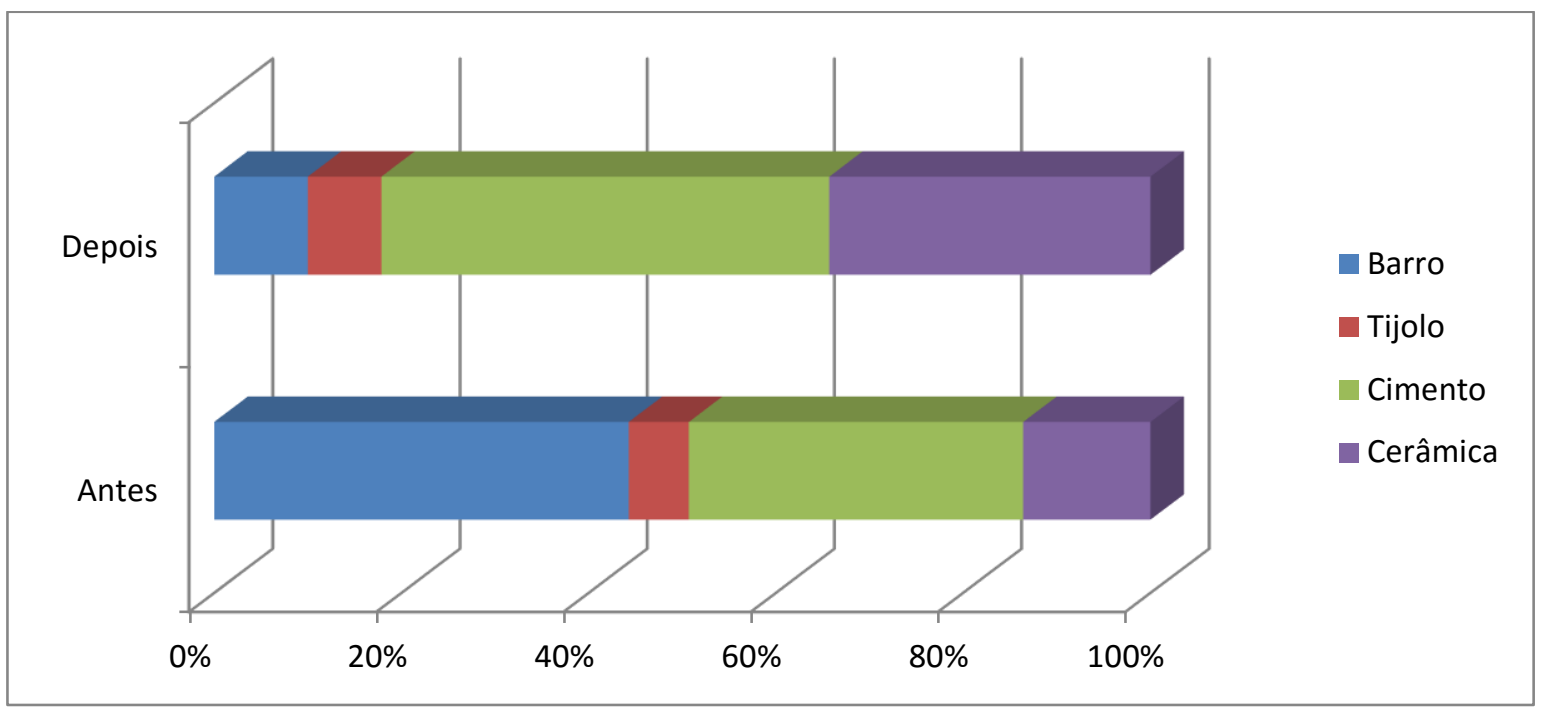

Figura 5.13 - Piso do domicílio

Quanto ao aspecto de iluminação das residências percebeu-se aí o maior ganho na qualidade de moradia para os moradores de Mateiros (FIG. 5.14). Relatos dos moradores mostraram que as condições habitacionais anteriores ao turismo eram de uso de lamparina a querosene ou velas e/ou lampião a gás. Esses dados corroboram aqueles encontrados por Magalhães et al. (2013) em que afirmam que essa abrangência no número de domicílios atendidos pela rede elétrica se deve à criação do "Programa Nacional de Universalização do Acesso e Uso da Energia Elétrica - Luz para Todos", que foi instituído pelo governo federal em 2003. Esse programa objetivou levar energia gratuitamente para a população do meio rural. Não há como negar os ganhos de qualidade de vida quanto ao aspecto social das famílias, tanto de saúde, quanto de bem estar mesmo. Mas, não há como não perceber a falta de investimento estadual em energias alternativas, como por exemplo, a energia solar, que inegavelmente é menos impactante do que as usinas hidroelétricas ou termoelétricas. Principalmente em termos de prevalência de sol na região, bem como, seu aspecto de isolamento geográfico, essa poderia ter sido uma cidade modelo para implantação de energias renováveis. 


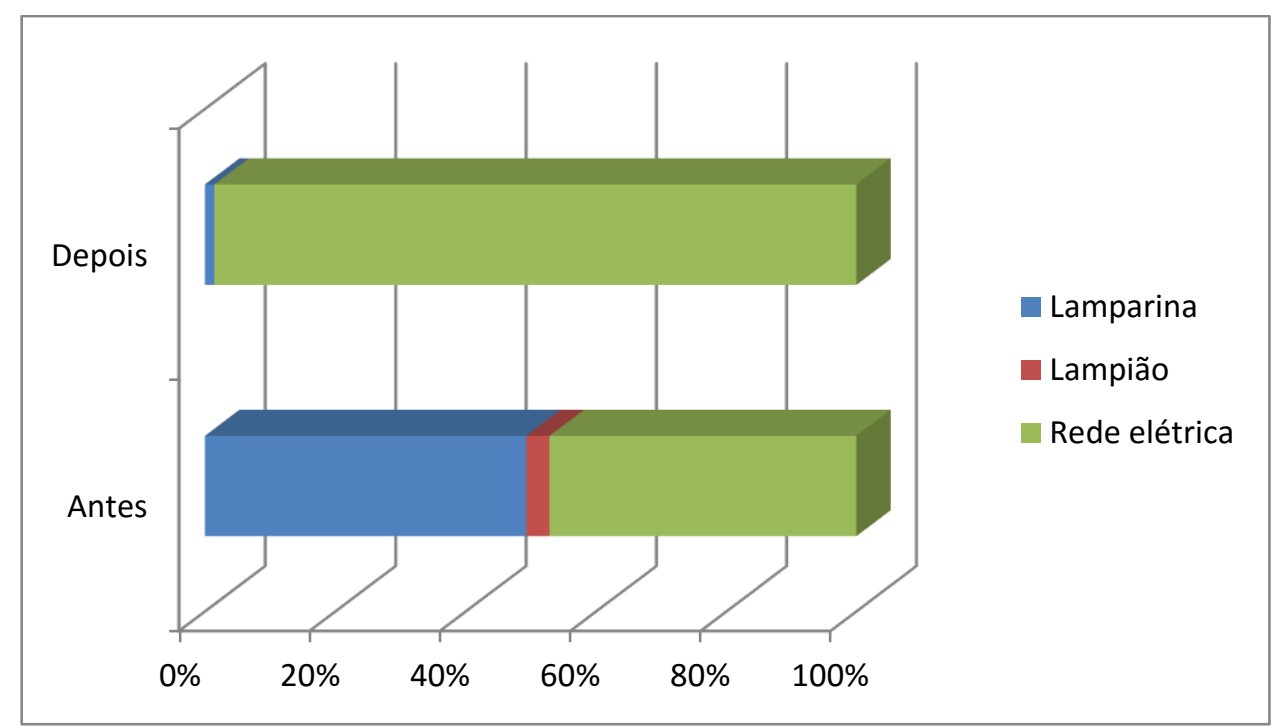

Figura 5.14 - Tipo de iluminação do domicílio

Em todos os indicadores foi perguntado ao final qual era o grau de satisfação quanto àqueles aspectos. No caso das condições de moradia, os resultados mostraram que tanto as respostas "ruins" quanto as "regulares" mostraram uma queda. Nas respostas "ruins" houve uma queda considerável. Ao mesmo tempo, as respostas "boa" demonstraram que a maioria da população está satisfeita com as atuais condições de moradia (60\%), mas que uma parcela considerável (38\%) ainda avalia que a atual condição pode avançar (FIG. 5.15).

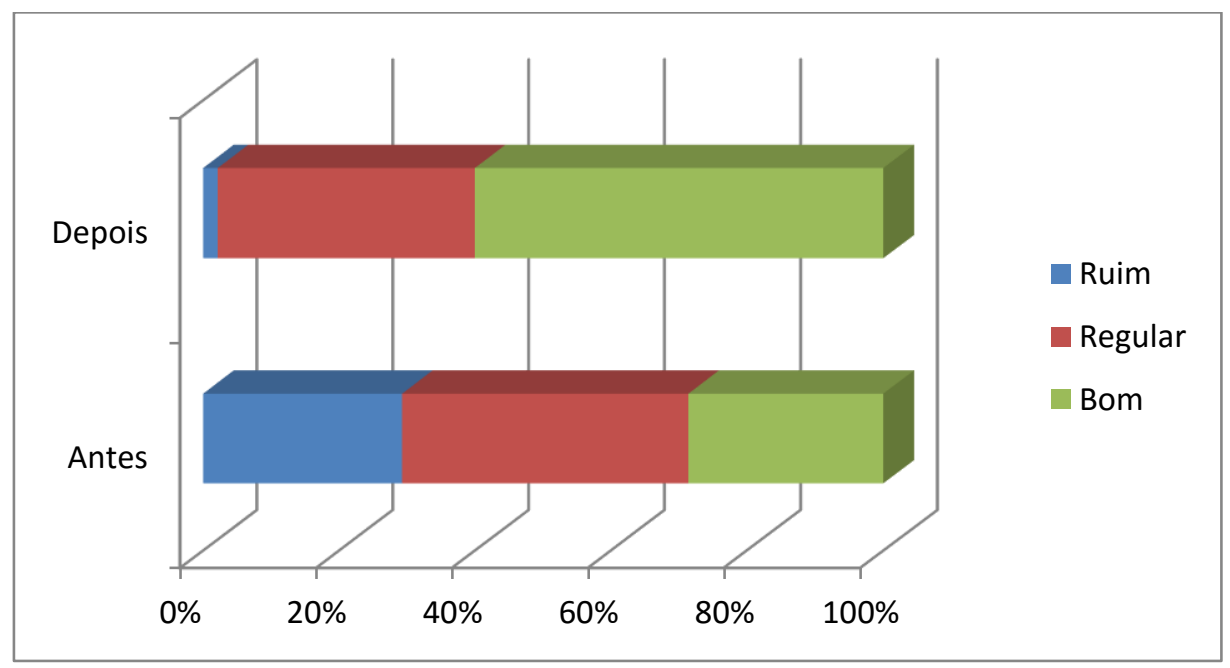

Figura 5.15 - Grau de satisfação com as condições de moradia 


\subsection{3 - Aspectos Sanitários}

Andrade et al. (2013) afirmam que o binômio qualidade das condições de saneamento e preservação ambiental é inversamente proporcional à prevalência de doenças parasitárias. $E$ os investimentos na área de saneamento ainda são incipientes. Giatti e Cutolo (2012) confirmaram isso ao compararem o crescimento no PIB e a evolução do percentual de atendimento domiciliar de ligações à rede de esgoto. Analisando os dados apenas do Tocantins que é o foco desse estudo, os autores nos mostram que enquanto a evolução do PIB per capita entre 2002 e 2009 foi de 14,2\% a evolução no número de domicílios atendidos pela rede de esgoto no mesmo período cresceu apenas 10,4\%, mostrando que não acompanhou a evolução do PIB. E a presente pesquisa mostrou que em Mateiros não foi diferente.

Observou-se que houve uma evolução nos aspectos sanitários, quando se analisa o item dejetos humanos pela FIG. 5.16, uma vez que houve uma diminuição nas respostas "céu aberto" e "enterrado". Apesar de ter aparecido a resposta "Rede de esgoto" por alguns entrevistados, soube-se que durante a coleta de dados dos Indicadores da ONU, já apresentados anteriormente, que não há rede de tratamento de esgoto e que o destino dado aos dejetos humanos da maioria das casas é a fossa. Atribui-se a essas respostas o desconhecimento da população para esse aspecto específico, pois por não ser visível ou estar encanado, considera-se como pertencente à uma rede de esgoto, mas não há central de tratamento do esgoto no local, segundo dados obtidos por entrevista junto à Prefeitura de Mateiros. 


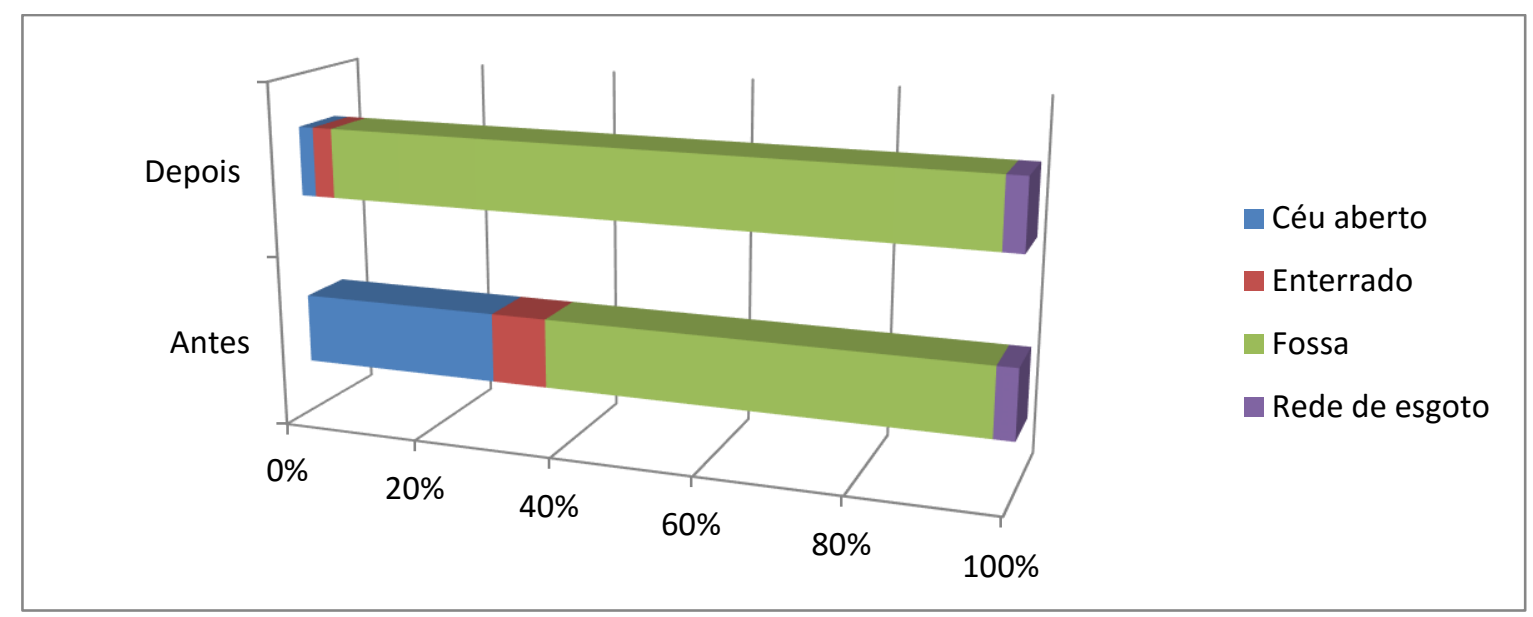

Figura 5.16 - Destino dado aos dejetos humanos segundo relato dos entrevistados

O lixo domiciliar coletado no local também mostrou ter dado um bom desempenho a esse indicador (FIG. 5.17). O que antes do turismo demonstra pela fala dos entrevistados que quase não havia coleta no local, e que os moradores ora deixavam a céu aberto, ora enterravam ou queimavam os lixos produzidos no local, passou a ter uma coleta realizada pela prefeitura. Se fossem analisados os dados para o indicador, isso poderia ter sido positivo, uma vez que se não queimavam o lixo, por exemplo, emitia-se menos $\mathrm{CO}_{2}$ na cidade. Mas, em entrevista com os gestores locais foi dito que há a coleta do lixo, como se pode notar na FIG. 5.18, mas não há tratamento do mesmo. Dessa forma, são depositados no 'lixão'. 


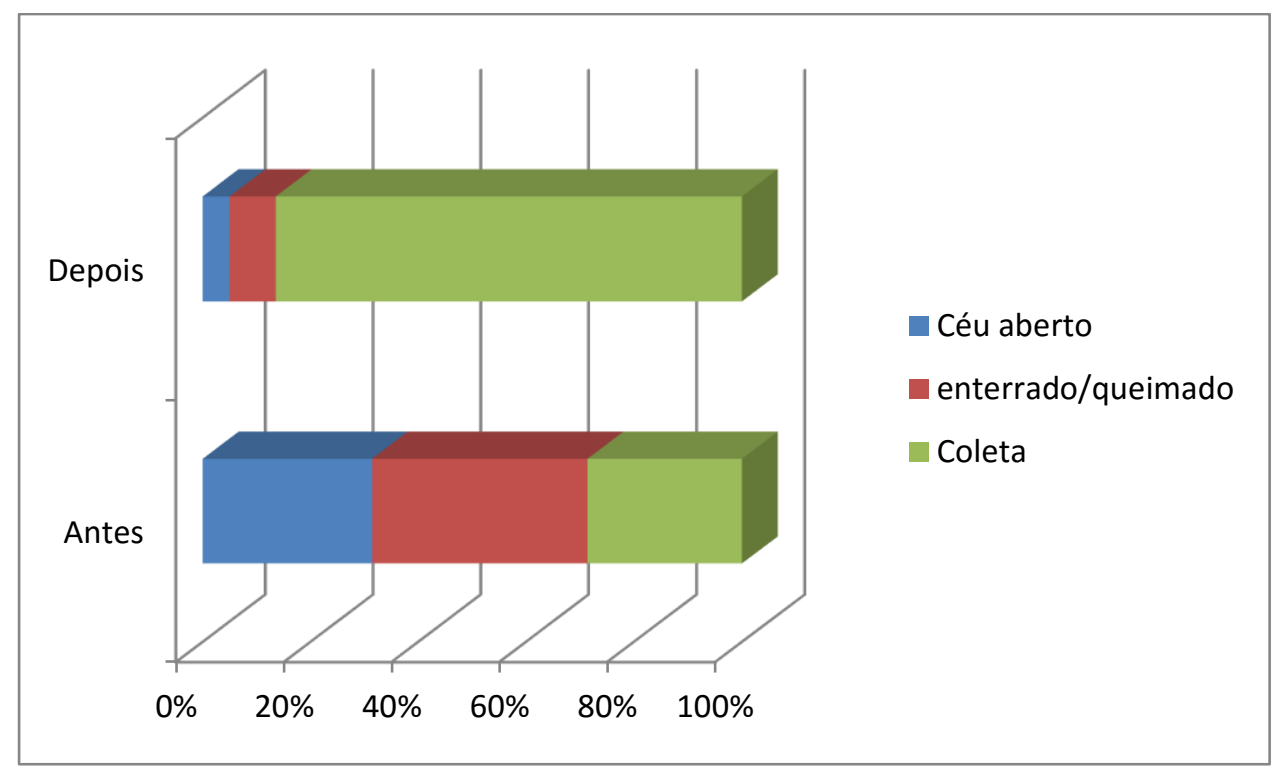

Figura 5.17 - Destino do resíduo domiciliar

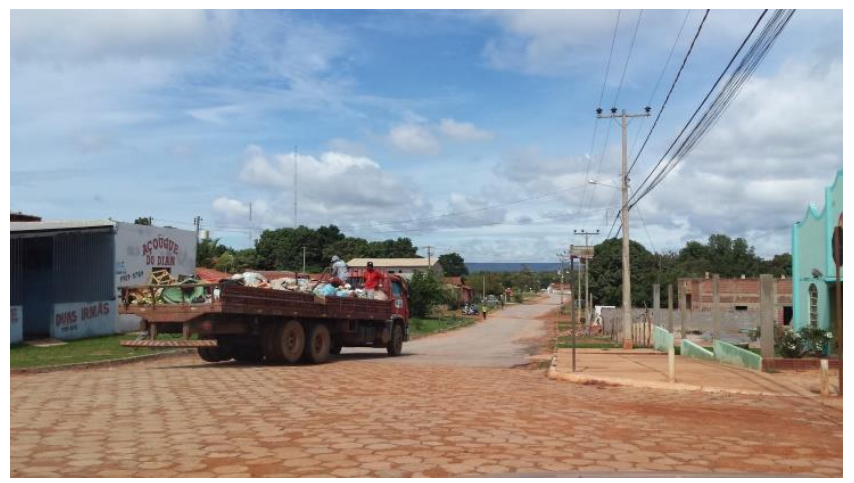

Figura 5.18 - Coleta do resíduo sólido na cidade de Mateiros.

As FIG. 5.19 e 5.20 retratam as condições do consumo da água na cidade de Mateiros. A primeira figura mostra que a origem da água anterior ao turismo era diretamente do rio. Os moradores, segundo alguns relatos, precisavam caminhar até o rio com seus utensílios e levar a água de volta para suas residências. Após os anos de 2000 foi instalada uma bomba que leva água do rio até as residências. Não havia nenhum tratamento dado a água até meados de julho de 2015. Acredita-se que o percentual da população que respondeu que a água era tratada se referia ao fato da prefeitura disponibilizar pastilhas de cloro para uso na água a ser consumida. Mas o próprio prefeito reconhece que a procura pelas pastilhas sempre foi muito pequena. 


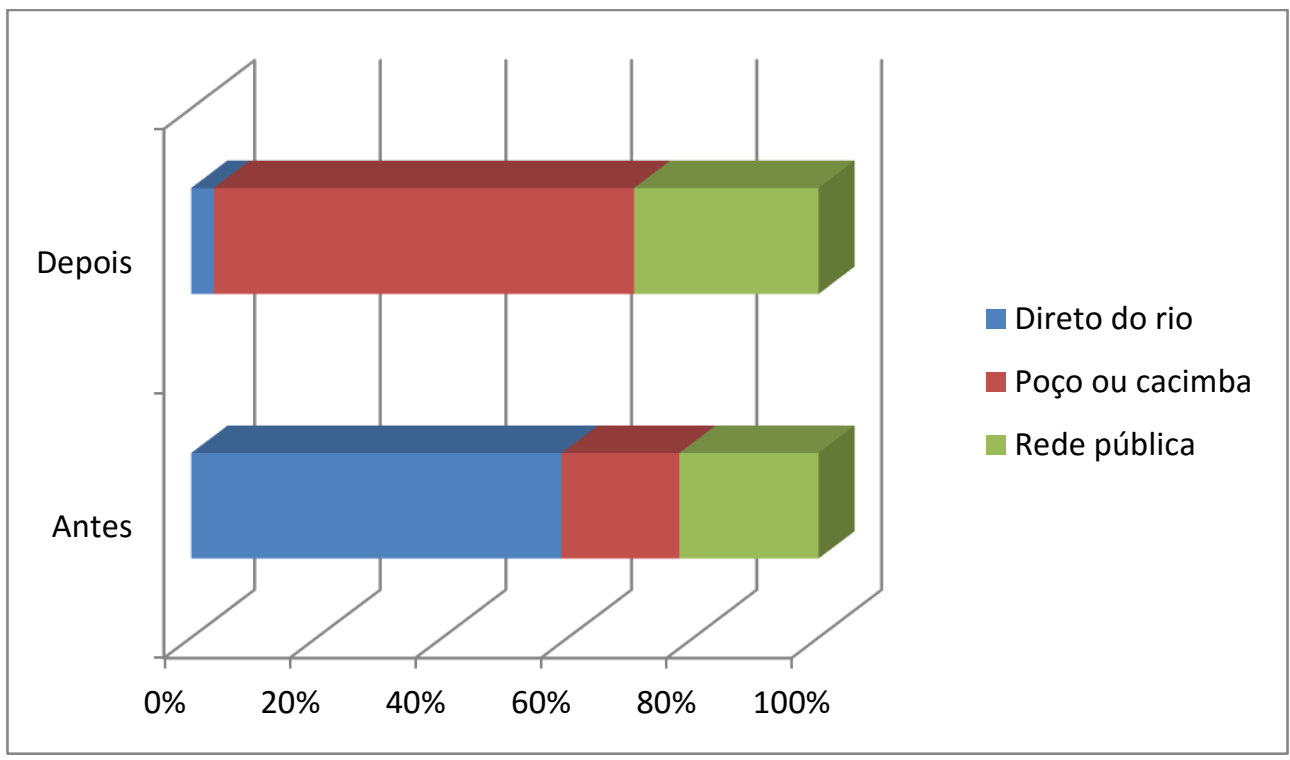

Figura 5.19 - Origem da água para consumo humano.

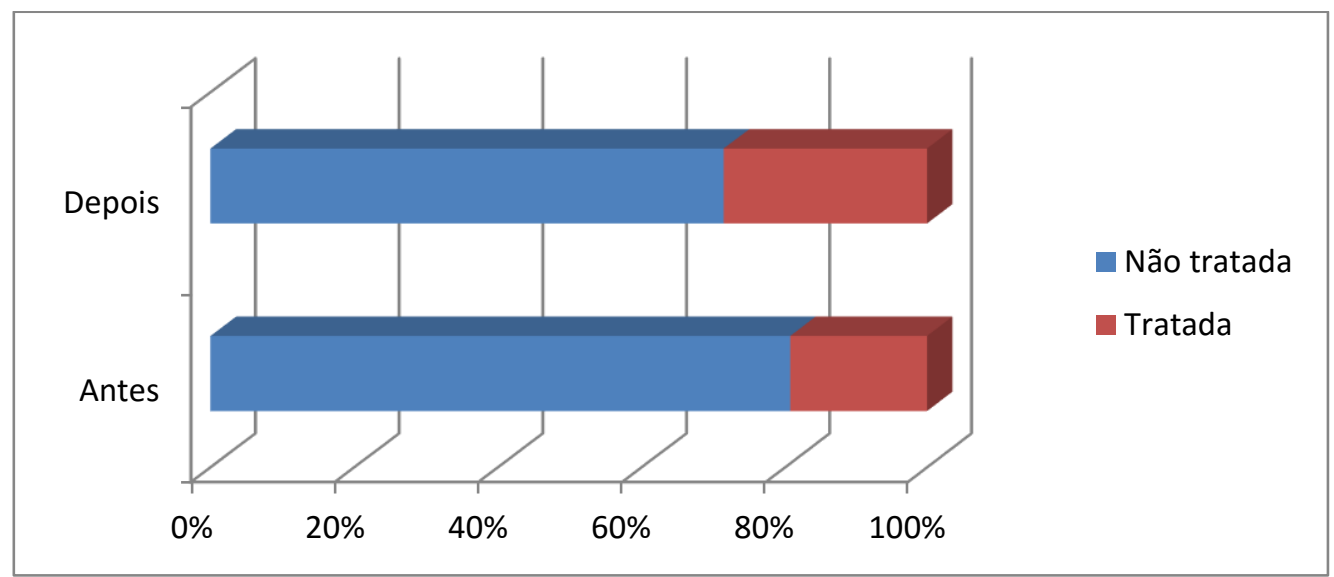

Figura 5.20 - Tratamento dado à água para consumo

Como pode se notar nas FIG. 5.21 e 5.22, os moradores precisavam colocar tecidos que funcionam como filtro nas saídas da água nas torneiras para que não viessem misturadas com areia ou outras substâncias. Alguns moradores relataram que há criação de gado próxima às áreas em que é realizado o bombeamento da água, o que pode indicar que essa água não é apropriada para o consumo humano. Segundo a Primeira-Dama da cidade, Mateiros disponibilizava as pastilhas de cloro no posto de saúde da comunidade, mas poucos moradores iam até o local para retira-las, o que 
indica que a água não recebia os tratamentos mínimos para consumo humano. Em recente entrevista veiculada em mídia estadual (Toledo, 2015) a Defensoria Pública entrou com ação civil pública contra o Governo do Estado do Tocantins para que promovessem obras de água e esgoto em junho de 2015. O município dispõe de água tratada após julho de 2015. Em novembro de 2015, o diretor de produção da Agência de Saneamento do Tocantins (ATS) informou em entrevista que iniciou em junho de 2015 a manutenção dos poços artesianos já existentes na cidade. No mesmo mês realizou-se a análise da água aonde foi possível verificar a presença de ferro e manganês em uma dose tolerável para consumo humano. E em agosto de 2015 iniciou-se a implantação de tratamento da água por meio de pastilhas de cloro e ampliação da rede em mais quase $2 \mathrm{~km}$ de extensão. $O$ diretor disse que um dos entraves desse processo está no grande desperdício de água na região, pois até então, a água não era cobrada. Disse que "começará a implantação dos hidrômetros nas residências de Mateiros e, após uma campanha de sensibilização da comunidade, em trinta dias iniciariam as cobranças".

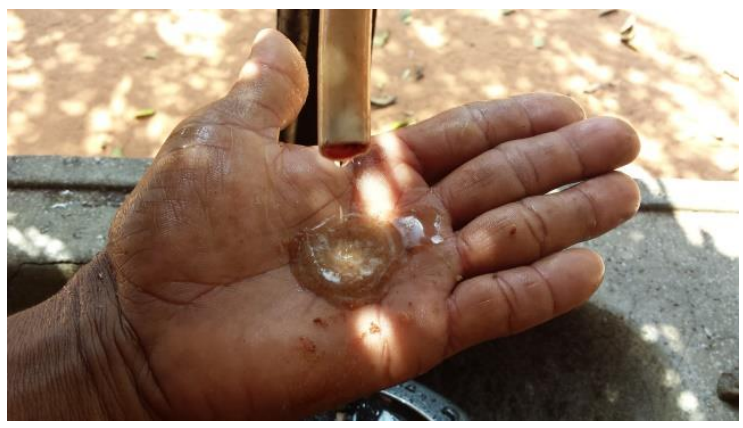

Figura 5.21: Água saindo da torneira de um morador entrevistado.

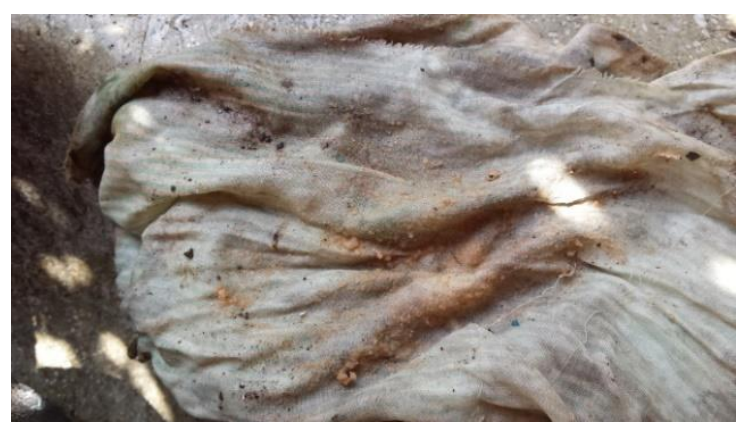

Figura 5.22: Condição do tecido colocado na torneira para impedir acesso da areia junto com a água.

Quanto ao grau de satisfação dos moradores nesse indicador, a FIG. 5.23 demonstra que a população não se sente plenamente satisfeita. Houve progresso, é certo, mas os valores mostram que uma pequena minoria considera-se satisfeita com a situação. A maior parte descreve como ruim ou 
regular as condições sanitárias do local, o que demonstra que o poder público deve buscar investir mais em ações que visem a implementação de condições dignas para os moradores de Mateiros.

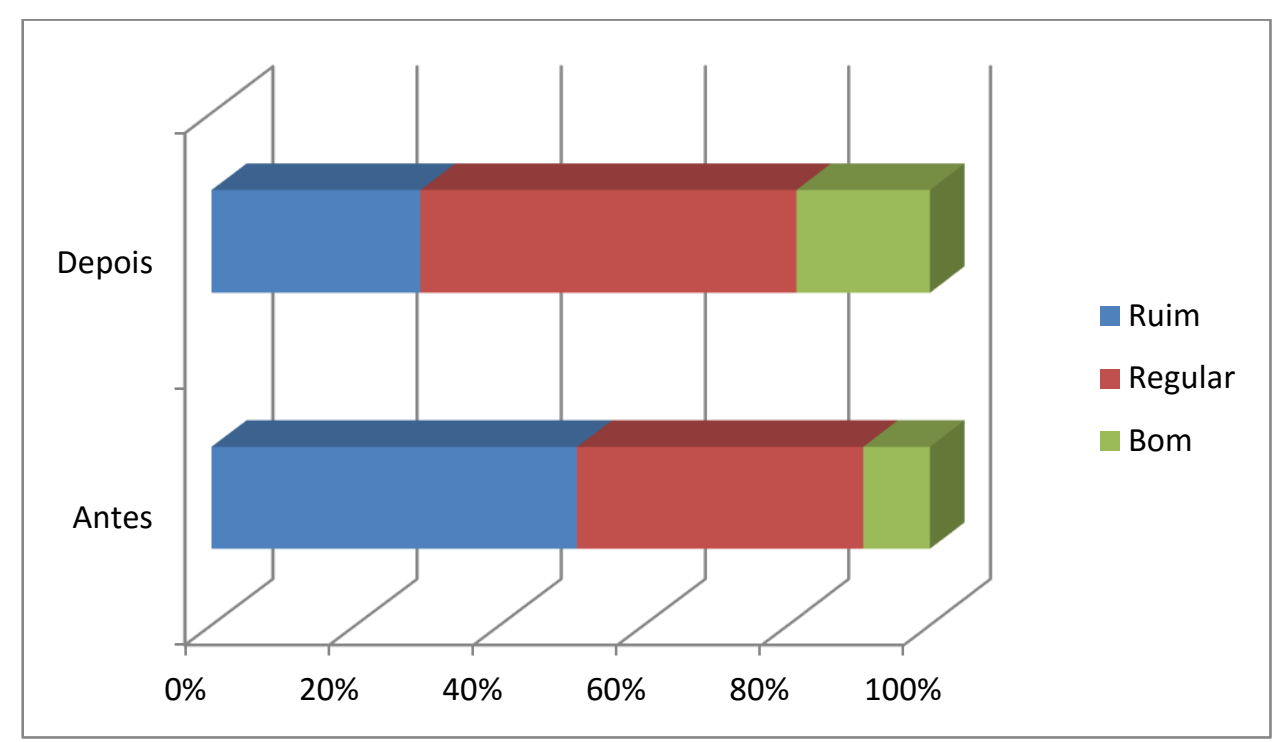

Figura 5.23 - Grau de satisfação com as condições sanitárias

\subsection{4 - Aquisição de bens de consumo duráveis}

Foi perguntado aos entrevistados sobre qual o seu acesso aos bens de consumo duráveis que foram divididos em dois grupos e comparados o seu acesso anterior e posterior ao início das atividades com o turismo. Os resultados foram agrupados aos que não tinham acesso aos bens descritos, tinham acesso a pelo menos um dos bens do grupo 1 e nenhum do dois ou possuidor de pelo menos um dos bens dos grupos 1 e 2 , conforme questionário Apêndice D. A seguir, a análise dos dados.

Discutiu-se anteriormente o conceito de qualidade de vida. Sabe-se que ela vai muito além do conceito de ter, mas não há como negar que essa relação de consumo esteja presente nesse conceito. Westphal (2003) já descreveu que a qualidade de vida "contempla aspectos relacionados às condições materiais da vida e à subjetividade nas relações dos homens entre si e com a natureza". Nesse sentido, o acesso a bens de consumo teve uma elevação considerável de antes e após a atividade turística em Mateiros, como 
pode ser notado na FIG. 5.24. A maioria das respostas demonstra que houve uma elevação na aquisição de bens nos dois grupos após o turismo, tendo com destaque no primeiro grupo os equipamentos: televisão, ventilador, geladeira, e no segundo grupo antena parabólica e telefone. Isso indica que houve uma elevação nas condições econômicas da cidade após o ano de 2000 e foi possível a população local adquirir tais bens.

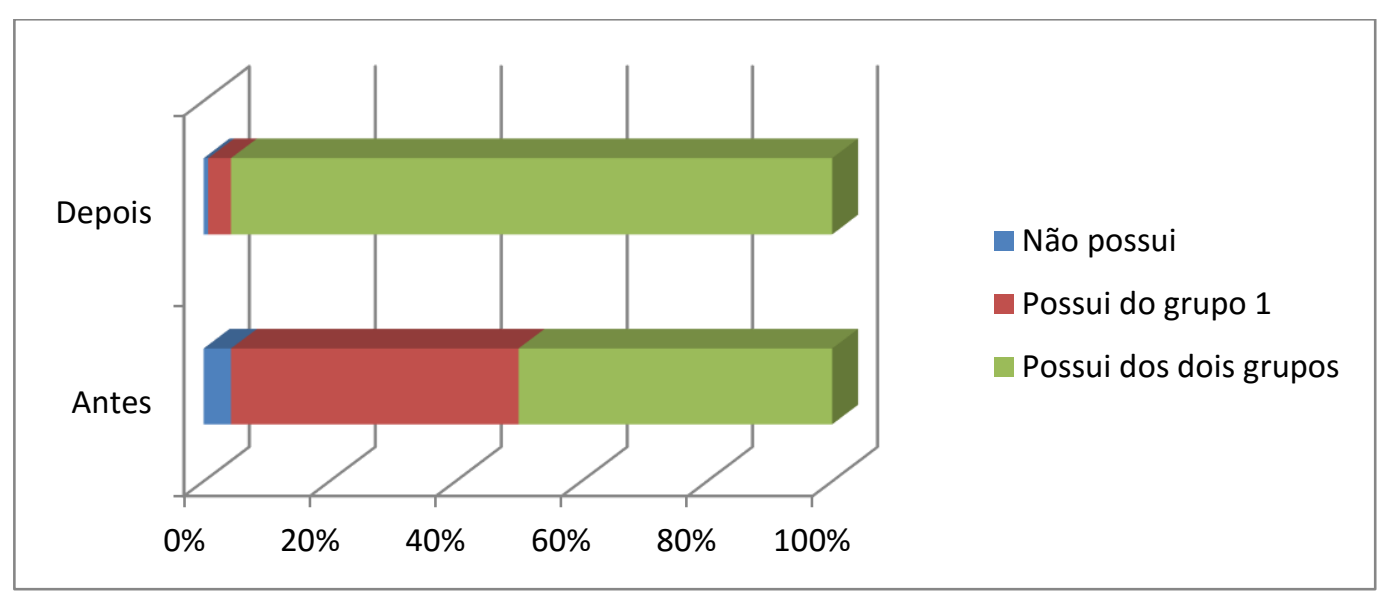

Figura 5.24 - Acesso a bens de consumo duráveis

Quanto ao grau de satisfação com a aquisição de bens de consumo, a FIG. 5.25 demonstra que houve uma redução considerável nas respostas "ruim", mas ainda assim houve um aumento nas respostas "regular". Isto denota que apesar dos moradores considerarem que seu padrão de vida tenha avançado após o surgimento do turismo, ainda há muitos moradores que consideram que podem avançar ainda mais essas condições. Isso foi percebido nas falas dos moradores ao longo das entrevistas. Muitos se diziam felizes com o que tinham, mas ao mesmo tempo, consideravam que desejavam adquirir algo que não tinham ou ainda renovar algum bem que tinham e desejavam algo mais novo. 


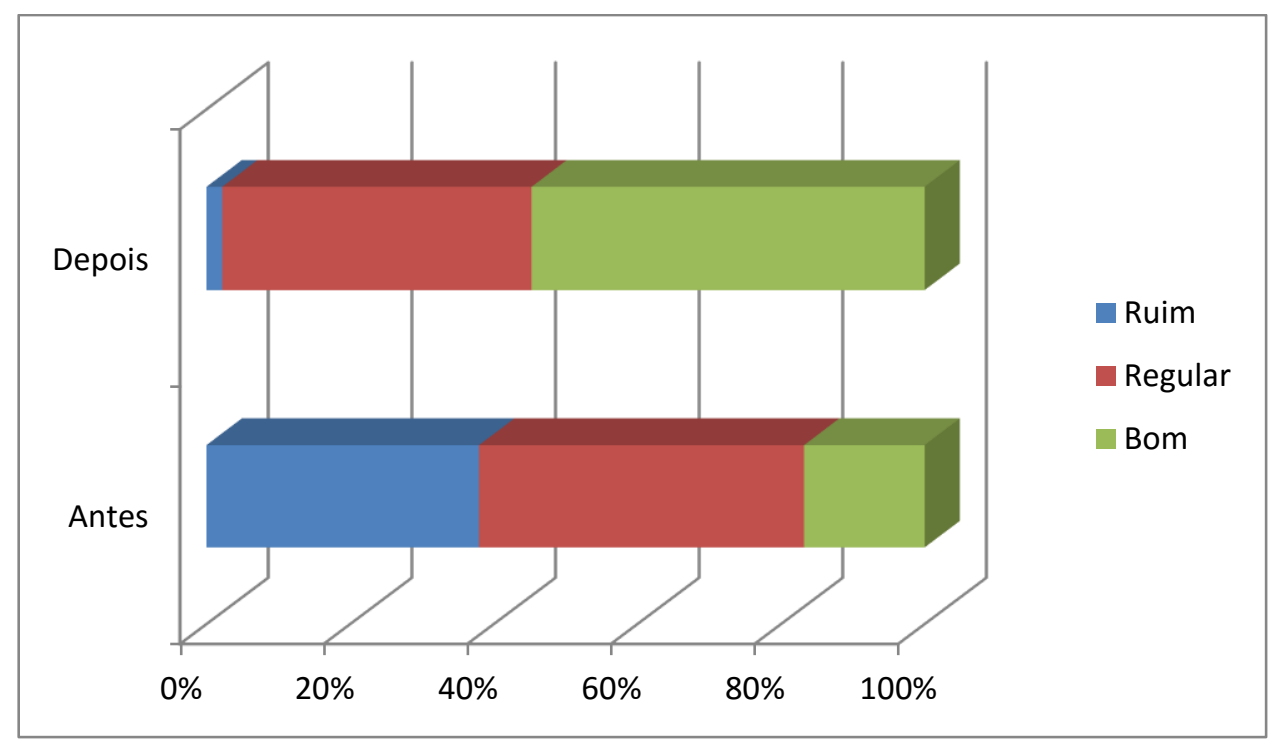

Figura 5.25 - Grau de satisfação em relação ao acesso a bens de consumo duráveis

\subsection{5 - Comunicação e Lazer}

Perguntou-se também qual era o seu acesso aos principais meios de comunicação disponíveis na atualidade, seja rádio, televisão, jornais e revistas ou ainda internet. Vale lembrar que devido ao isolamento geográfico da cidade de Mateiros, o acesso atualizado a jornais e revistas fica dificultado. Para fins de cálculo do IQV foram agrupados da seguinte maneira: (1) quem não tinha acesso a nenhum meio de comunicação; (2) quem ouve rádio e assiste televisão, mas não tem acesso a jornais e revistas (3) quem tem acesso a todos os meios de comunicação, menos internet (4) quem tem acesso a todos os meios de comunicação e internet.

A FIG. 5.26 mostra que houve um aumento considerável apenas no acesso à internet. Esta falta de acesso a jornais e revistas, como foi dito anteriormente, se deve ao isolamento em que se encontra a cidade de Mateiros, bem como, ao alto índice de analfabetos (42\%) e o baixo nível de escolaridade que pode ser constatado neste trabalho no indicador sobre educação e que será apresentado mais adiante. Em razão disso, dificulta a comunidade em acessar informações via esse meio de comunicação. Ao mesmo tempo, o grande crescimento da internet pode proporcionar à comunidade acesso aos mesmos e tirá-los dessa limitação às informações. 
Matias e Matos (2013) citam Castells (1999) para afirmar que a internet tem se tornado um meio essencial de comunicação e organização em todas as esferas de atividades, que vão dos movimentos sociais e processos políticos, até atuar, informar, organizar e dominar um ciberespaço, além é claro de auxiliar a rede de consumo.

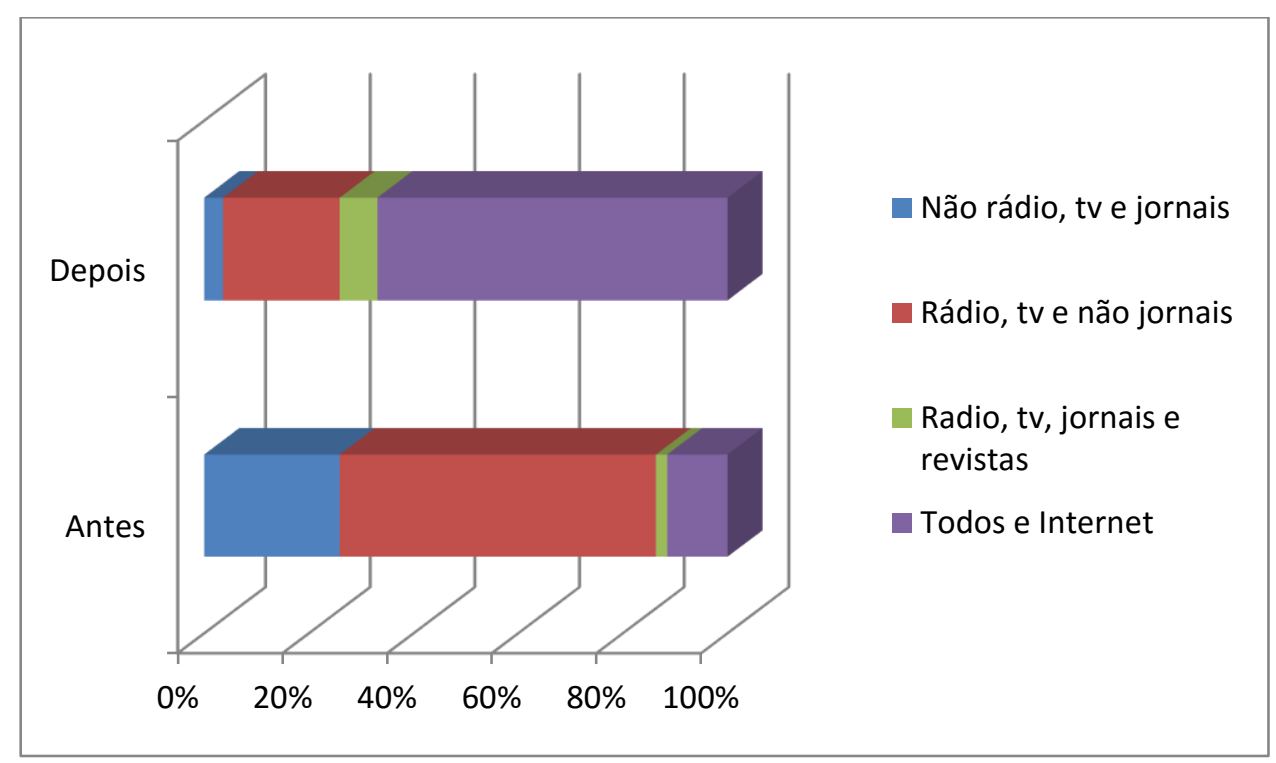

Figura 5.26 - Acesso aos meios de comunicação

Nos aspectos de atividades de lazer Silva et al. (2013) destacam a importância que os espaços de lazer dão vida às cidades, permitindo sociabilidade, reunindo diferentes grupos em torno do espaço, possibilitando a redução da violência das ruas. Nesse panorama, acredita-se que não houve mudanças consideráveis nos espaços de lazer da cidade de Mateiros (FIG. 5.27). As respostas mais citadas foram futebol, centro recreativo e ambientes naturais. Não variando muito do antes e depois do turismo. Isso pode indicar que não foram construídos muitos espaços de socialização na comunidade. 


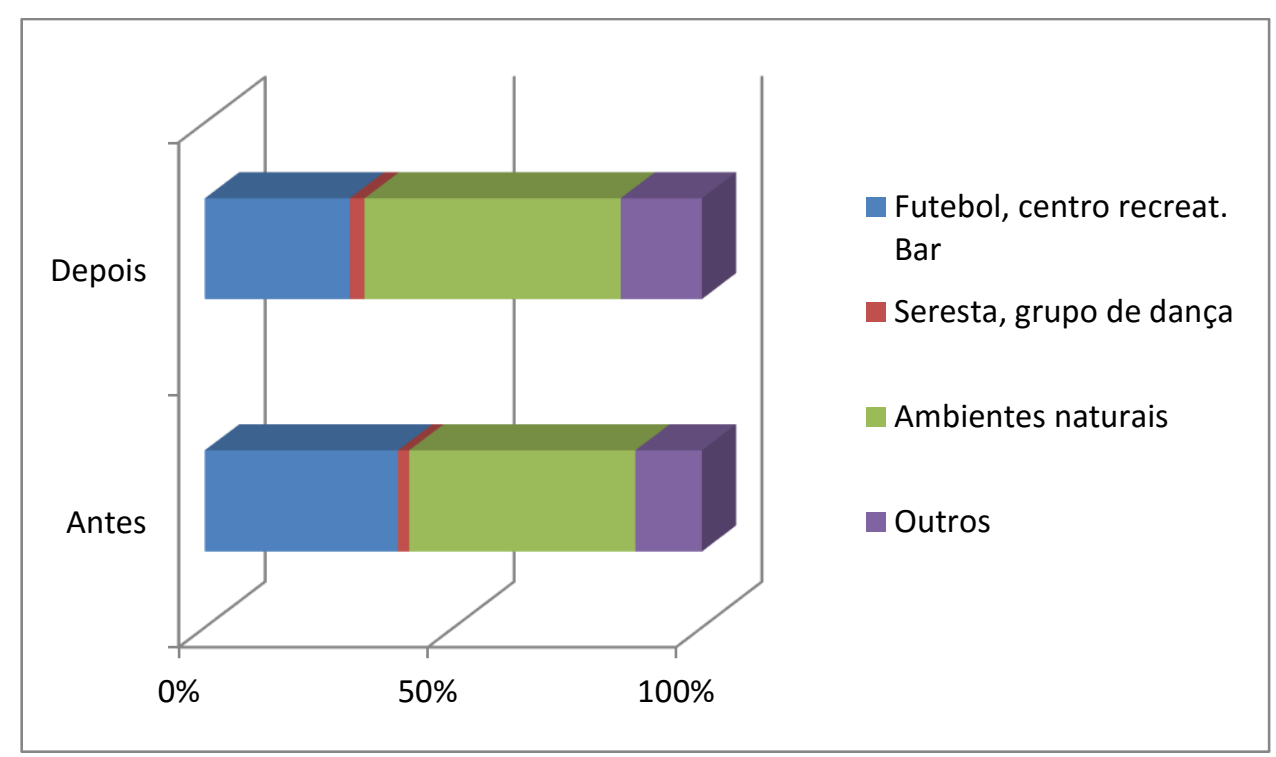

Figura 5.27 - Atividades de lazer

\subsection{6 - Saúde}

A saúde é um dos indicadores que possuem maior destaque para a qualidade de vida de uma comunidade. Souza e Carvalho (2003) afirmam que uma boa saúde é o melhor recurso para o progresso pessoal, econômico e social e uma dimensão importante da qualidade de vida. Os autores destacam que a Organização Mundial da Saúde classifica em cinco dimensões a qualidade de vida: (1) saúde física, (2) saúde psicológica, (3) nível de independência (em aspectos de mobilidade, atividades diárias, dependência de medicamentos e cuidados médicos e capacidade laboral), (4) relações sociais e (5) meio ambiente.

Nesse sentido o indicador da saúde demonstrou que houve um pequeno avanço nas condições de prestação de serviços de saúde na região comparados antes e após o turismo. A FIG. 5.28 mostra que a maioria dos entrevistados considerou que havia um posto de saúde na região, mas comparativamente houve um decréscimo nas respostas de inexistência de posto de saúde ou ainda no atendimento por agente de saúde antes do turismo e um aumento considerável nas respostas que há um posto de saúde com atendimentos básicos. 


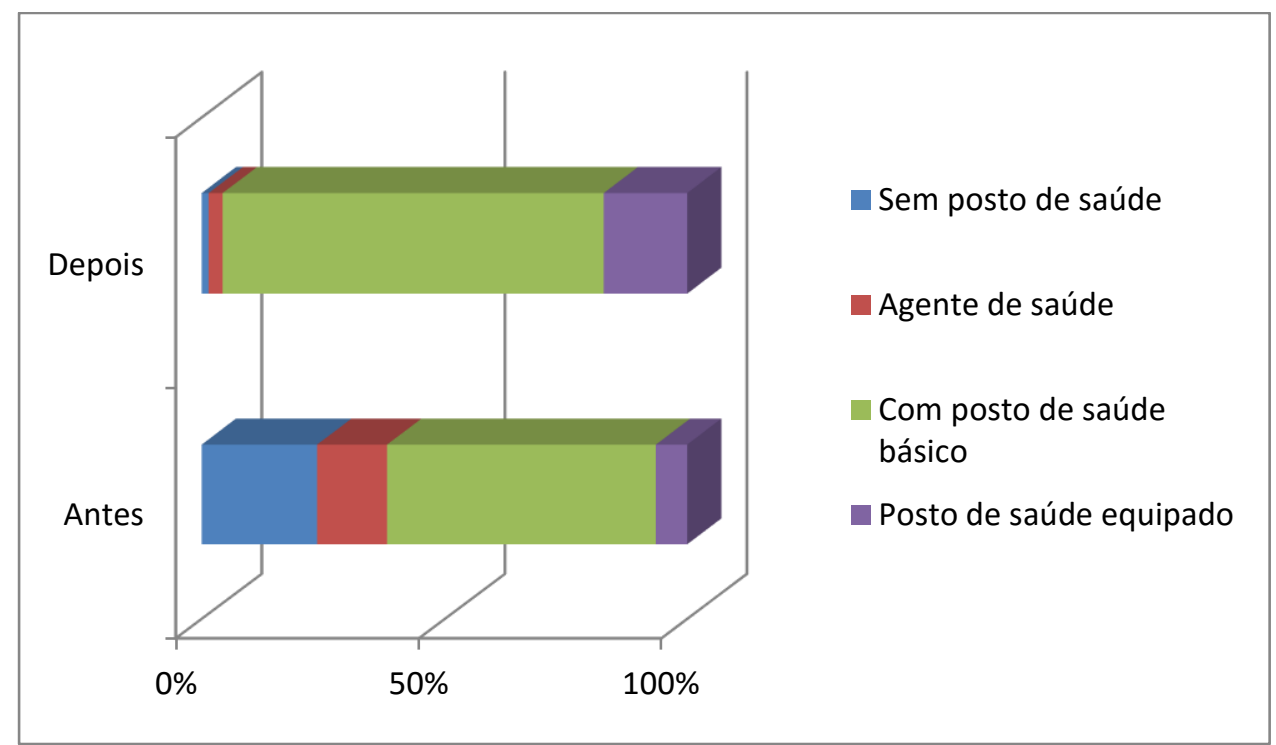

Figura 5.28 - Prestação de serviços de saúde na comunidade.

Esse é verdadeiramente um problema no município. As narrativas orais mostraram que há apenas um médico que atende na cidade, mas que vem do município vizinho, Dianópolis, que fica a $246 \mathrm{~km}$ de Mateiros, para realizar os atendimentos agendados. Isso traz consequências inclusive para a atividade turística, pois há a necessidade de uma estrutura mínima para receber esse turista, o que pode implicar até em mortes devido às condições da estrada. $\mathrm{Na}$ fala do Prefeito da cidade um dos entraves no desenvolvimento local se dá em virtude dessas condições de saúde, pois o município precisa encaminhar seus pacientes com emergências para a cidade de Porto Nacional. Esta fica a 263 km de distância em uma estrada precária que pode levar mais de 9 horas e que em boa parte do ano necessita de um veículo com tração 4X4 para conseguir transpô-la. Além disso, em caso de haver a necessidade do paciente realizar exames, a prefeitura acaba arcando não só com o transporte desses moradores, mas com hospedagem até que se façam os exames necessários, comprometendo assim boa parte do orçamento municipal.

Ao mesmo tempo a maioria da comunidade mostra-se satisfeita com as condições atuais da saúde. Quando analisado o grau de satisfação com as condições de saúde percebeu-se que $48 \%$ da população respondeu que as condições antes do turismo eram ruins e 39\% respondeu que era regular. Ao passo que após o turismo esse percentual cai para $15 \%$ de pessoas que 
consideram como sendo ruim e $41 \%$ responderam regular. Ainda assim, o percentual de $44 \%$ que consideram as condições de saúde no local como boas deve ser reanalisado. Acredita-se que esses números sejam reflexo da comparação de antes e do depois do turismo. O que antes mostrava uma condição precária hoje parece melhor. Mas pelo relato do Prefeito e de alguns moradores observou-se que a análise para esse indicador não tenha sido eficaz.

\subsection{7 - Educação}

O grau de instrução dos entrevistados pode ser visto na FIG. 5.29. Observou-se que a maior faixa concentra-se em $1^{\circ}$ ao $4^{\circ}$ anos $(28 \%)$ e ensino médio completo (26\%). O percentual de entrevistados que concluíram o curso superior foi considerado baixo em virtude de existir apenas a modalidade de educação a distância com curso de Pedagogia e curso de Letras em parceria com o Governo do Estado. Isso demonstra que mais ações devem ser realizadas na região de modo a ampliar a oferta de cursos para que menos jovens precisem sair da região para estudar.

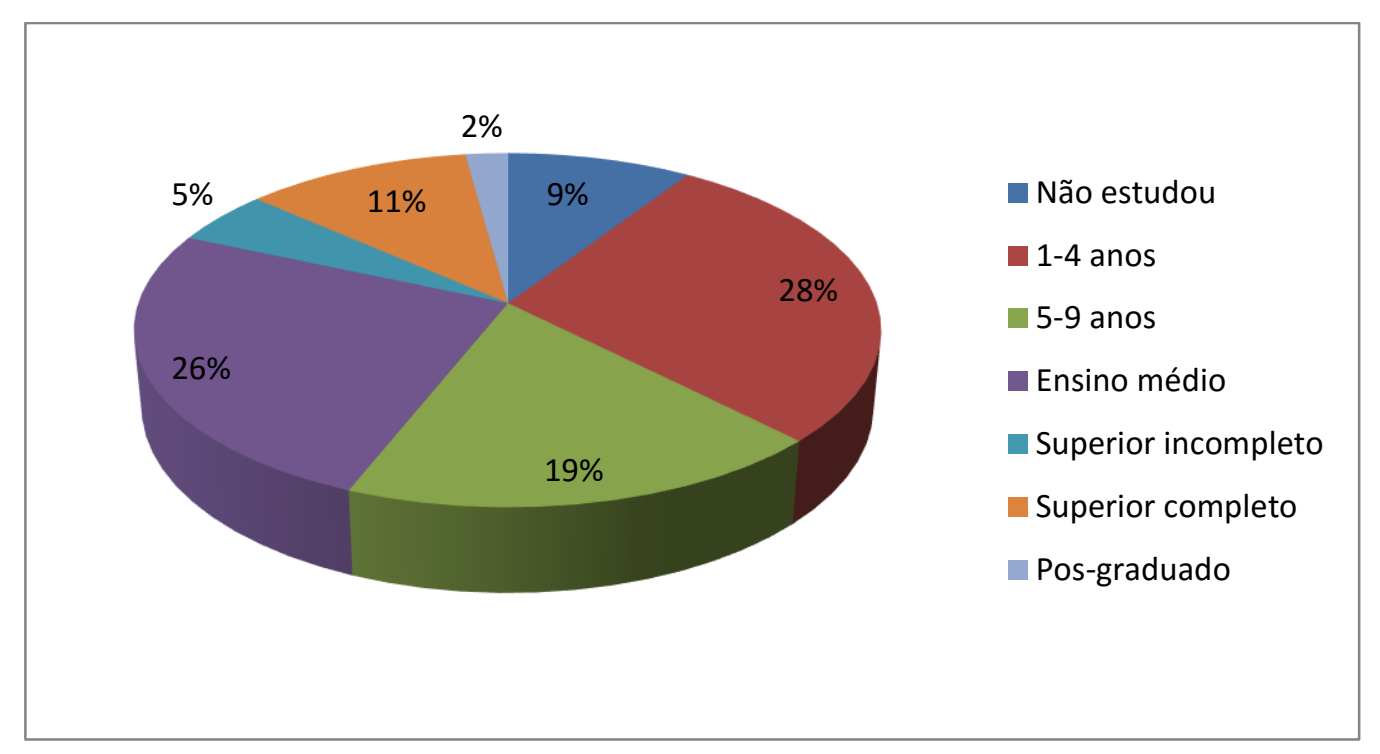

Figura 5.29 - Grau de instrução do entrevistado

Da mesma forma, houve um substancial avanço no grau de satisfação da comunidade com relação à Educação (FIG.30). Muitos sinalizaram que antes do turismo era ruim (39\%) ou regular (36\%). Após o surgimento do 
turismo alguns moradores afirmam que a atual condição ficou boa (55\%) e outros afirmam que ainda está regular (35\%).

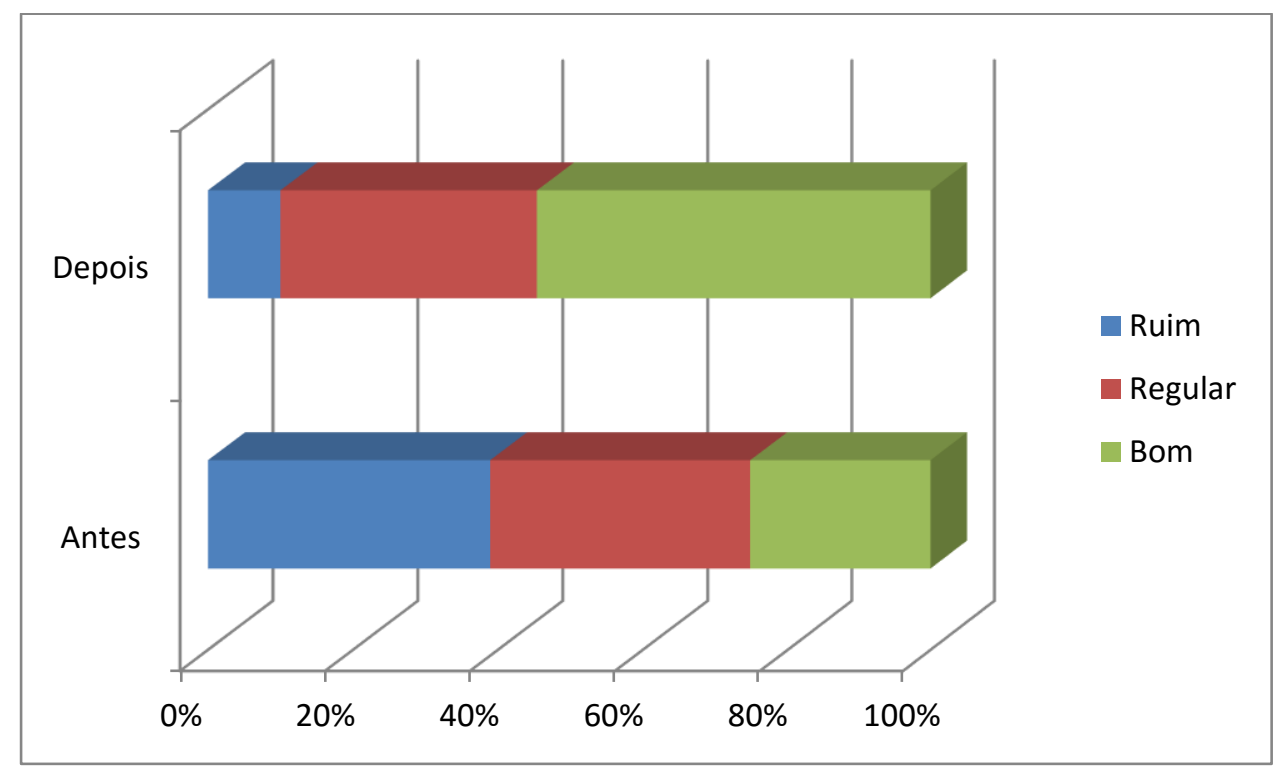

Figura 5.30 - Grau de satisfação em relação ao nível de educação da família

\subsection{8 - Emprego e Renda}

A FIG. 5.31 descreve que houve um ligeiro avanço na renda familiar antes e após o turismo. Mais da metade dos entrevistados (54\%) viviam com menos de um salário mínimo antes do turismo. Após o surgimento do turismo houve um acréscimo no percentual da população entrevistada (60\%) que vive com um ou dois salários mínimos por mês. Apesar de ainda ser considerado baixo, o aumento deve ser considerado para fins de cálculo do IQV. Vale lembrar que não se deve atribuir ao turismo esse aumento na renda da população, pois soma-se a isso um percentual da população que vive com auxílio do governo por meio de bolsa-família (40\%) a partir do ano de 2004 que deve ser analisado. 


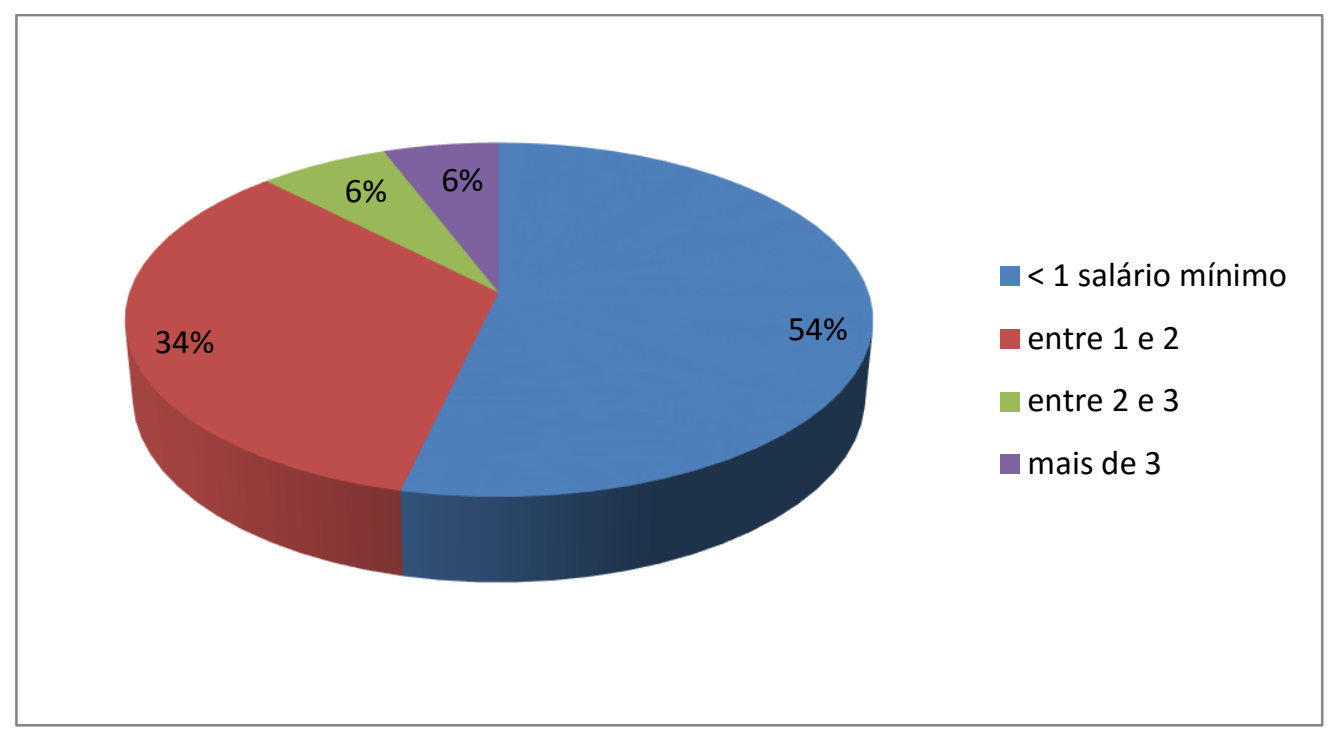

Figura 5.31 - Renda familiar

Como pode se perceber na FIG. 5.32, a maior parte dos entrevistados recebe auxílio do programa bolsa família (22\%), tem como renda o comércio (18\%) ou são servidores públicos (16\%). Apenas uma pequena parcela sobrevive exclusivamente do turismo (10\%). A FIG. 5.33, porém demonstra que alguns moradores atuam com o turismo como forma de complementar a renda mensal. Desses que atuam com turismo formalmente ou informalmente, $56 \%$ atuam com artesanato de capim dourado, 24\% atuam em serviços turísticos, como hotéis, bares e restaurantes, $12 \%$ como condutores ambientais e $8 \%$ atuam no Centro de Atendimento ao Turista.

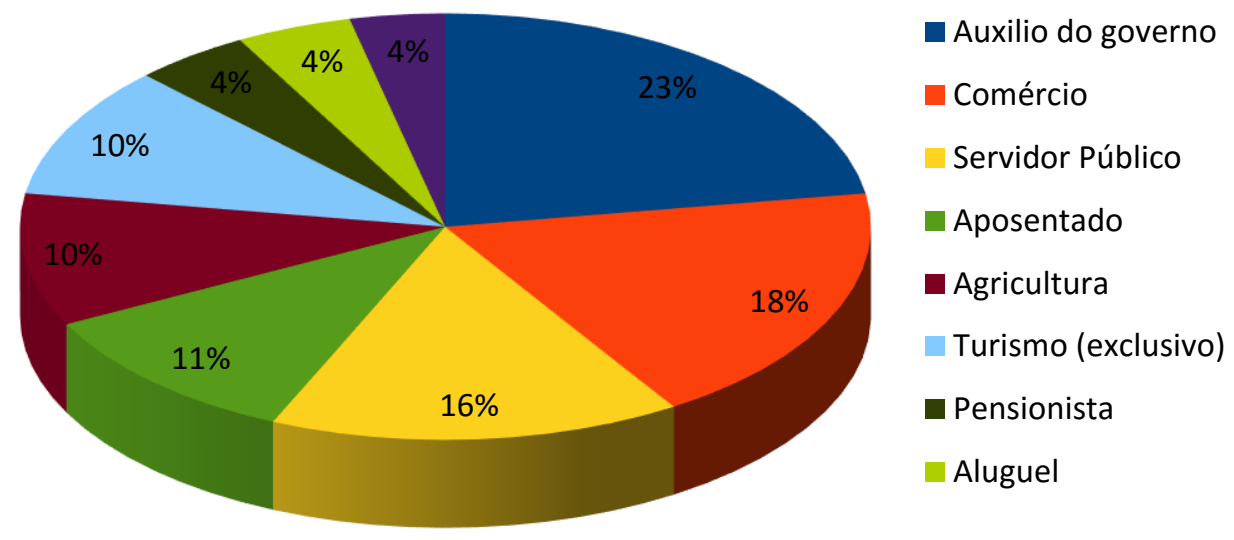

Figura 5.32 - Fonte de Renda das famílias de Mateiros/TO 


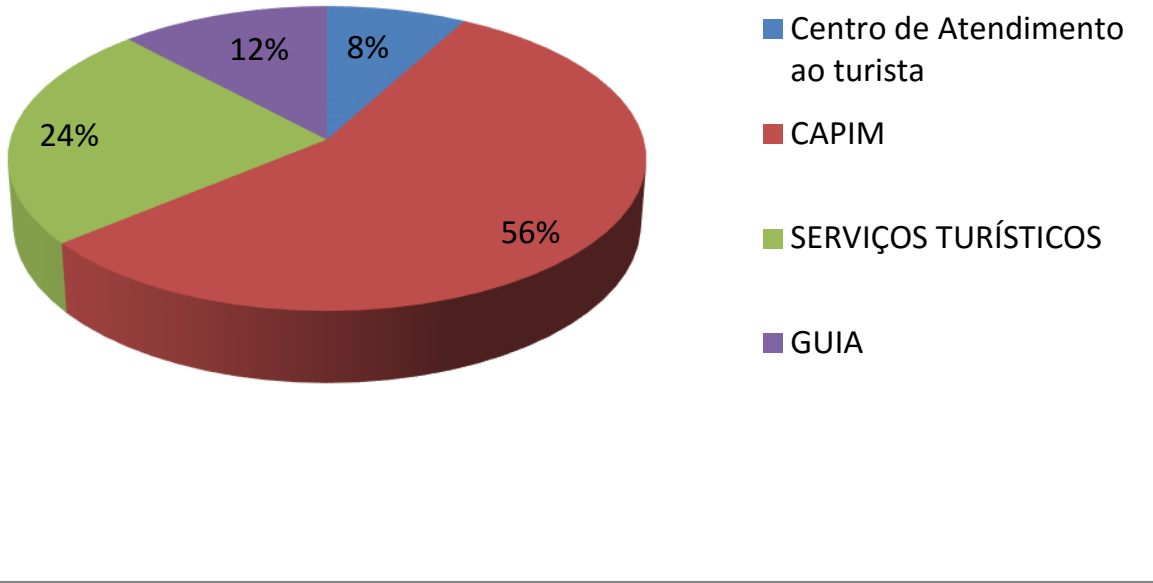

Figura 5.33 - Famílias que utilizam o turismo para complementar a renda

A pesquisa revelou que apenas $19 \%$ da população dizem receber aposentadoria, bem como, apenas $8 \%$ se declararam pensionistas, $8 \%$ dizem possuir algum imóvel alugado e $6 \%$ recebem ajuda financeira de algum filho ou parente.

\subsection{9 - Meio Ambiente}

Foi perguntado também quais eram as situações percebidas pelos moradores com relação ao meio ambiente, a saber, queimadas e desmatamentos, agressão ao meio ambiente da exploração das atividades turísticas, agricultura e pecuária como atividades que agridem 0 meio ambiente, a exploração de espécies, e a exploração mineral como atividade impactante na região. A FIG. 5.34 mostra que a maioria dos moradores percebe até dois itens dentre os citados anteriormente (62\%), sendo queimadas e exploração de espécies foram as respostas que mais se destacaram. Isto demonstra que há a necessidade de maior sensibilização da população até para que sejam agentes de fiscalização. Ao mesmo tempo, 49\% consideram como regular o grau de satisfação em relação a preservação do meio ambiente no local (FIG. 5.35). 


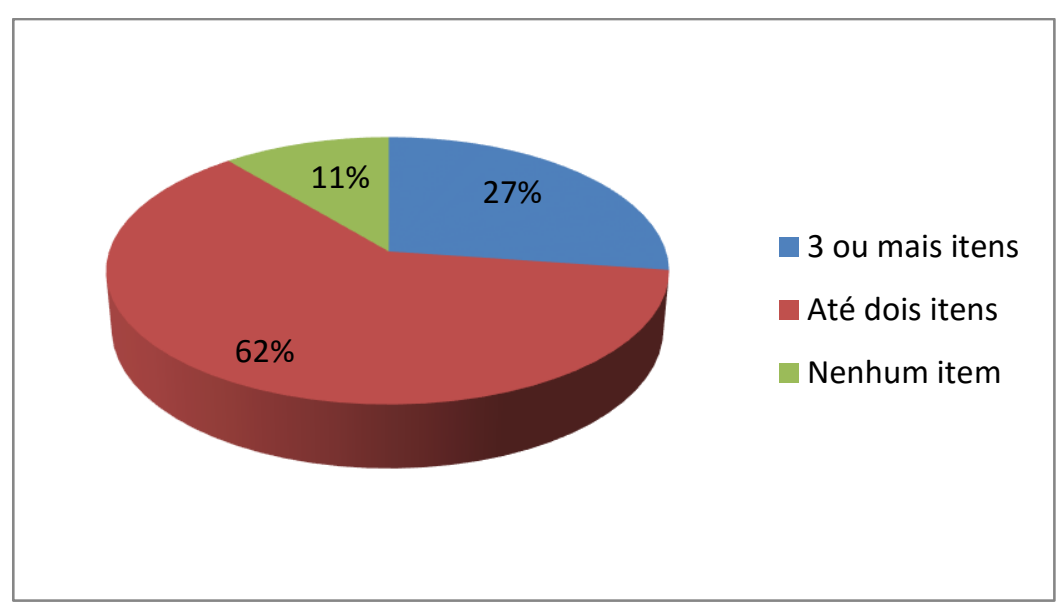

Figura 5.34 - Situações que são percebidas com relação ao meio ambiente

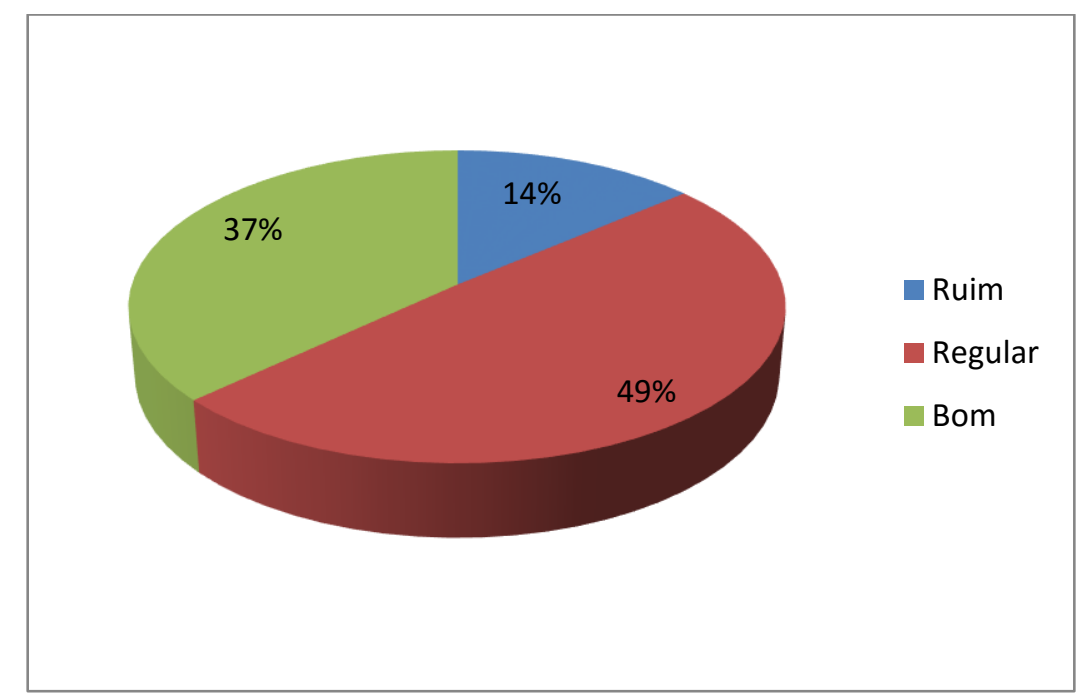

Figura 5.35 - Grau de satisfação em relação a preservação do meio ambiente local.

\subsubsection{0 - Consolidação dos dados do Índice de Qualidade de Vida de Mateiros}

Após as análises individuais dos indicadores propostos, pode-se notar na TAB. 5.2 a contribuição de cada indicador para compor o índice de qualidade de vida das famílias de Mateiros/TO comparativamente antes e após estabelecimento da atividade de turismo na região do Jalapão. 
Tabela 5.2 - Valores dos indicadores e do IQV, obtidos na cidade de Mateiros/TO, antes e após o estabelecimento da atividade turística.

\begin{tabular}{c|r|r|r}
\hline INDICADORES & ANTES & DEPOIS & $\%$ \\
\hline Sociais & & & 45,03 \\
\hline Condições de moradia & 0,110757 & 0,160638 & 33,17 \\
\hline Comunicação e lazer & 0,160757 & 0,214079 & 40,99 \\
\hline Saúde & 0,249409 & 0,351655 & 30,32 \\
\hline Educação & 0,144208 & 0,187943 & \\
\hline Econômicos & & & 79,77 \\
\hline Renda & 0,019127 & 0,034386 & 37,89 \\
\hline Bens de consumo duráveis & 0,316312 & 0,43617 & \\
\hline Ambientais & & & 50,72 \\
\hline Aspectos Sanitários & 0,082033 & 0,123641 & \\
\hline Meio Ambiente & 0,214894 & 0,215426 & \\
\hline IQV & 0,162187 & 0,215426 & $\mathbf{3 2 , 8 3}$ \\
\hline Incremento ao IQV & $\mathbf{0 , 1 6 2 1 8 7}$ & $\mathbf{0 , 2 1 5 4 2 6}$ & \\
\hline
\end{tabular}

Percebe-se que houve um incremento ao IQV de $32,82 \%$ na cidade de Mateiros após o estabelecimento do turismo, com destaque para as famílias que atuam na produção das peças de artesanato de capim dourado, conforme dados da pesquisa. As alterações, na ordem de 0,162 para 0,215, apresentadas na TAB. 5.2 e nas FIG. 5.36 e 5.37 indicam que apesar de ter havido uma elevação na qualidade de vida das famílias entrevistadas os valores para esse índice, de acordo com a metodologia proposta, ainda permaneceram em baixo nível, isto é, com valores entre $0<\mathrm{IQV}>0,499$, demonstrando que a qualidade de vida das famílias não é satisfatória.

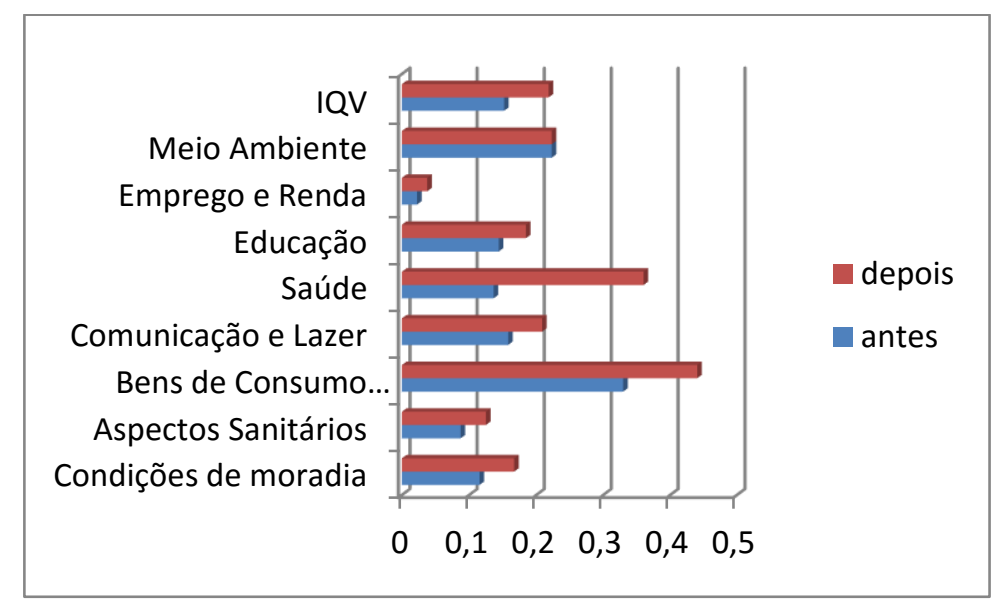

Figura 5.36 - Valores dos Indicadores e do IQV de antes e depois do turismo das famílias que atuam com turismo 


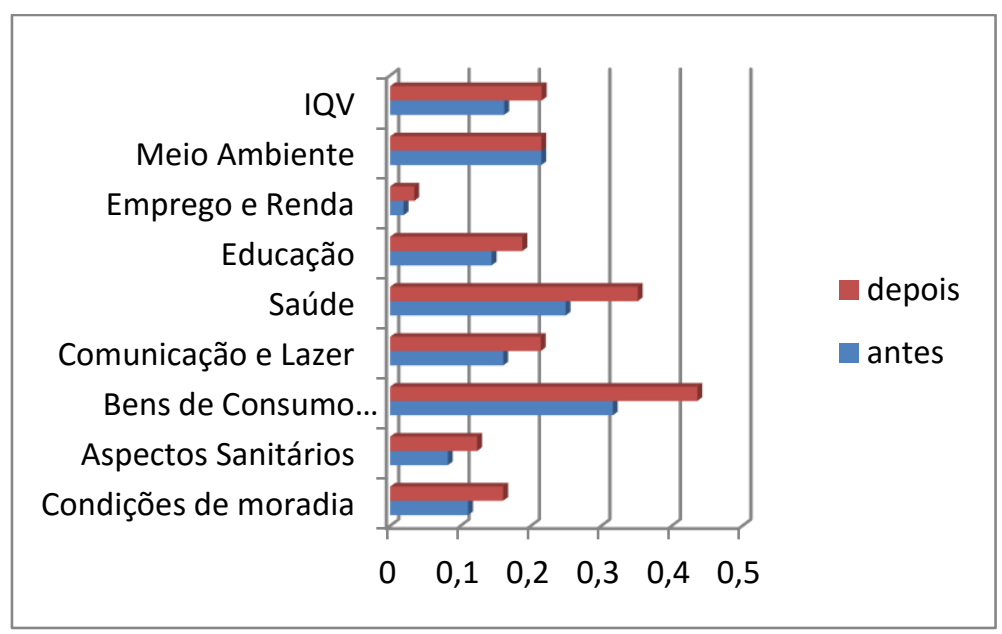

Figura 5.37 - Valores dos Indicadores e do IQV de antes e depois do turismo de todas as famílias entrevistadas.

Ainda assim, mesmo com um baixo nível de qualidade de vida a cidade de Mateiros, demonstrou por meio das narrativas orais, que se mantém satisfeita com suas condições de vida, apesar de reconhecerem que muito deve ser feito em todas as esferas dos indicadores propostos, dando ênfase para aspectos sanitários, saúde e educação, conforme relatos de moradores.

Este estudo corrobora o trabalho desenvolvido por Santos et al. (2007) que analisou a qualidade de vida da comunidade de Mumbuca, localizada na região de Mateiros, onde foi possível concluir também que mesmo com os índices considerados baixos a comunidade se mantinha satisfeita com as condições de então, por considerar que houve significativos avanços na qualidade de vida da população.

\subsubsection{1 - Análise comparativa das variáveis do Índice de Qualidade de Vida de Mateiros}

Foram realizadas comparações entre o escore final do índice de qualidade de vida da população de Mateiros e as seguintes variáveis: gênero, idade, escolaridade, os que atuam ou não com turismo e os que recebem ou não a bolsa família. 
A análise iniciou-se com a descrição da amostra. Observou-se que a maioria dos respondentes é de sexo feminino (67\%), tem idade de 26 a 55 anos (64\%), sendo a idade média de 38 anos, estão no ensino médio ou já terminaram o ensino médio (54\%), tem atuação com turismo (52\%) e não tem bolsa família (60\%), conforme dados da TAB. 5.3:

Tabela 5.3: Frequência absoluta e relativa das variáveis da amostra e média, mediana, desvio padrão mínimo e máximo da variável idade

\begin{tabular}{llcc}
\multicolumn{1}{c}{ Variável } & \multicolumn{1}{c}{ Categoria } & $\mathrm{N}$ & $\%$ \\
\hline Sexo & Fem & 95 & 67 \\
& Masc & 46 & 33 \\
\hline Idade categorizada & 18 a 25 & 34 & 24 \\
& 26 a 55 & 90 & 64 \\
& $>56$ & 17 & 12 \\
\hline Escolaridade recategorizada (missing & Analfabeto & 3 & 4 \\
$56)$ & Alfabetização/ Ens. Fundamental & 6 & 7 \\
& Ensino médio & 46 & 54 \\
& Técnico, Superior e Pós-graduação & 30 & 35 \\
\hline Turismo & Não & 67 & 48 \\
& Sim & 74 & 52 \\
\hline Bolsa Família (missing $=1)$ & Não & 84 & 60 \\
& Sim & 56 & 40 \\
\hline Idade & Média & 37,52 \\
& Mediana & 36,00 \\
& Desvio padrão & 14,40 \\
& Mínimo & 18,00 \\
& Máximo & 82,00
\end{tabular}

Posteriormente foi avaliada a variável de interesse IQV, observou-se que a média e mediana do momento antes foi de 0,16 e do momento depois foi de 0,22 , sendo que esta diferença é estatisticamente significativa ( $p$-valor $<0.0001$ ) pelo teste de Wilcoxon para amostras pareadas, segundo a TAB. 5.4. 
Tabela 5.4: Média, mediana, desvio padrão, mínimo e máximo de IQV antes, depois e da diferença (depois - antes) seguido do p-valor do teste de Wilcoxon pareado para diferença entre os momentos de avaliação

\begin{tabular}{|c|c|c|c|c|c|}
\hline IQV & Média & Mediana & $\begin{array}{l}\text { Desvio } \\
\text { padrão }\end{array}$ & Mínimo & Máximo \\
\hline Antes & 0,16 & 0,16 & 0,05 & 0 & 0,27 \\
\hline Depois & 0,22 & 0,22 & 0,04 & 0 & 0,29 \\
\hline $\begin{array}{l}\text { Diferença (Depois - } \\
\text { Antes) }\end{array}$ & 0,05 & 0,06 & 0,04 & $-0,04$ & 0,15 \\
\hline $\mathrm{p}$-valor & & & & & $<0,0001$ \\
\hline
\end{tabular}

Por fim, foi feita a análise de associação entre as variáveis da amostra e o IQV antes, depois e a diferença. O teste utilizado foi o Mann-Whitney para sexo, turismo e bolsa família e o Kruskal-Wallis para escolaridade e idade, conforme TAB. 5.5.

Verifica-se que no momento antes (IQV antes) existe associação da escolaridade ( $p$-valor 0,0244 ) e presença do bolsa família ( $p$-valor 0,0140 ) quanto ao IQV, sendo que quanto maior a escolaridade, maior o IQV e quem não tem bolsa família tem maior IQV do que quem tem bolsa família.

No momento posterior observa-se que a associação de sexo ( $p$-valor 0,00010 ) e escolaridade ( $p$-valor 0,0011 ) quanto ao IQV, sendo que o sexo feminino apresentou maior IQV e quanto maior a escolaridade maior o IQV.

A análise do IQV depois deve ser feita com cautela pois ela não indica o efeito do momento da mensuração na qualidade de vida. Para avaliar se houve alguma categoria das variáveis da amostra que apresentou maior melhora de IQV é necessário fazer o teste de associação com a variável diferença de IQV (depois - antes). Observa-se que apenas a variável bolsa família ( $p$-valor 0,0138 ) apresenta associação com a melhora da qualidade de vida, sendo que quem tem bolsa família apresentou maior melhora de qualidade de vida do que quem não tem bolsa família, embora novamente deve ser destacado que quem não tem bolsa família tem maior IQV. 
Tabela 5.5: Média, mediana e desvio padrão de IQV antes e depois e diferença para cada categoria das variáveis sexo, idade, escolaridade, atividade turismo e bolsa família, seguidos do p-valor do teste de Mann-Whitney e Kruskal-Wallis*

\begin{tabular}{|c|c|c|c|c|c|c|c|c|c|}
\hline \multirow{3}{*}{ Variáveis } & \multicolumn{9}{|c|}{ IQV } \\
\hline & \multicolumn{3}{|c|}{ Antes } & \multicolumn{3}{|c|}{ Depois } & \multicolumn{3}{|c|}{$\begin{array}{c}\text { Diferença } \\
\text { (depois - antes) }\end{array}$} \\
\hline & Média & Mediana & $\begin{array}{l}\text { Desvio } \\
\text { padrão }\end{array}$ & Média & Mediana & $\begin{array}{l}\text { Desvio } \\
\text { padrão }\end{array}$ & Média & Mediana & $\begin{array}{l}\text { Desvio } \\
\text { padrão }\end{array}$ \\
\hline \multicolumn{10}{|l|}{ Sexo } \\
\hline Fem & 0,17 & 0,17 & 0,05 & 0,22 & 0,22 & 0,03 & 0,06 & 0,07 & 0,04 \\
\hline Masc & 0,16 & 0,15 & 0,04 & 0,21 & 0,21 & 0,03 & 0,05 & 0,05 & 0,04 \\
\hline \multicolumn{10}{|l|}{ Idade } \\
\hline 18 a 25 & 0,17 & 0,17 & 0,04 & 0,23 & 0,23 & 0,02 & 0,06 & 0,06 & 0,04 \\
\hline 26 a 55 & 0,16 & 0,16 & 0,05 & 0,22 & 0,22 & 0,02 & 0,05 & 0,06 & 0,04 \\
\hline$>56$ & 0,15 & 0,14 & 0,03 & 0,18 & 0,18 & 0,04 & 0,04 & 0,03 & 0,03 \\
\hline \multicolumn{10}{|l|}{ Escolaridade } \\
\hline Analfabeto & 0,13 & 0,13 & 0,02 & 0,19 & 0,19 & 0,01 & 0,05 & 0,06 & 0,01 \\
\hline Alfabetização/ Ens. Fundamental & 0,12 & 0,11 & 0,04 & 0,18 & 0,18 & 0,01 & 0,06 & 0,07 & 0,05 \\
\hline Ensino médio & 0,16 & 0,16 & 0,04 & 0,22 & 0,23 & 0,03 & 0,06 & 0,07 & 0,04 \\
\hline Técnico, Superior e Pós-graduação & 0,18 & 0,18 & 0,05 & 0,22 & 0,22 & 0,03 & 0,04 & 0,03 & 0,05 \\
\hline \multicolumn{10}{|l|}{ Atividade Turismo } \\
\hline Não & 0,16 & 0,16 & 0,04 & 0,21 & 0,22 & 0,03 & 0,06 & 0,07 & 0,04 \\
\hline $\operatorname{Sim}$ & 0,17 & 0,16 & 0,05 & 0,22 & 0,22 & 0,03 & 0,05 & 0,05 & 0,04 \\
\hline \multicolumn{10}{|l|}{ Bolsa Família } \\
\hline Não & 0,17 & 0,17 & 0,04 & 0,22 & 0,22 & 0,03 & 0,04 & 0,04 & 0,04 \\
\hline Sim & 0,14 & 0,13 & 0,04 & 0,22 & 0,22 & 0,02 & 0,07 & 0,08 & 0,03 \\
\hline p-valor Sexo & & & 0,5309 & & & 0,0010 & & & 0,0631 \\
\hline p-valor Idade* & & & 0,8494 & & & 0,1817 & & & 0,7233 \\
\hline p-valor Escolaridade* & & & 0,0244 & & & 0,0011 & & & 0,2307 \\
\hline $\mathrm{p}$-valor Atividade Turismo & & & 0,1383 & & & 0,2186 & & & 0,2648 \\
\hline p-valor Bolsa Família & & & 0,0140 & & & 0,4452 & & & 0,0138 \\
\hline
\end{tabular}




\section{3 - Cálculo da Pegada Ecológica do Turismo.}

Nesse item está descrito o cálculo da pegada ecológica do turismo em Mateiros/TO, no qual foram calculadas as áreas de terras de energia fóssil e terras construídas para cada categoria preestabelecida. Apresenta-se cada categoria dividida por subitem e ao final é apresentado o cálculo final da pegada ecológica do turismo. Houve uma grande dificuldade para obtenção de alguns destes resultados sendo necessárias mudanças na forma de se obter tais informações.

Algumas informações serão utilizadas recorrentemente para fins do cálculo por categorias, a saber, o número de turistas que visitam a região e o número de dias em que estes turistas permanecem na localidade. Desta forma, optou-se em apresentá-las inicialmente.

A primeira informação refere-se ao número de turistas que visitaram o Jalapão no ano de estudo. Por meio de entrevista com o gestor local do órgão ambiental do governo do Estado do Tocantins do Instituto Natureza do Tocantins - NATURATINS (Apêndice E) foi constatado que o único atrativo que era de responsabilidade do órgão, e no qual havia controle de acesso de entrada de turistas para visitação, era as Dunas. Foi por meio desse controle que foi realizada uma estimativa de quantos visitantes estiveram no Jalapão. Pela estimativa, no ano de 2014, período escolhido para realizar a pesquisa da Pegada Ecológica do Turismo (NATURATINS, 2015), 8.726 pessoas visitaram o atrativo.

Segundo informações obtidas por meio de entrevistas com proprietários e/ou gerentes de pousadas da região, o tempo médio de permanência dos turistas na cidade foi de três dias. Com base nestes dados, foi feito o cálculo da Pegada Ecológica do Turismo que será apresentada a seguir.

\subsection{1 - Categoria Transportes}

Neste subitem é apresentado o tipo de terra associada, a saber: Terras Construídas e Terras de Energia Fóssil.

\subsubsection{1 - Categoria Transporte - Subcategoria Terras Construídas.}

Para o cálculo da subcategoria Terras Construídas era necessário fazer uma estimativa do número de turistas de lazer que visitaram a região no ano 
escolhido para a investigação (8726), e a infraestrutura de transporte existente no local; no caso de Mateiros o acesso se dá em sua maioria via Palmas.

Quanto ao aspecto da infraestrutura de transporte existente no local, constatou-se que o principal meio de transporte utilizado para se deslocar até o local é o carro. O aeroporto local é de pequeno porte, não possuindo a infraestrutura necessária para recebimento de turistas, pois a pista não é asfaltada, não há sala de embarque e desembarque e os voos para o destino são realizados em sua maioria por autoridades governamentais e produtores rurais da região. Não há empresas que operem voos comerciais no local. Poderia utilizar-se o aeroporto de Palmas como parâmetro para calcular a área aeroportuária, por ser esse o aeroporto mais próximo do destino turístico, apesar dos mais de $360 \mathrm{~km}$ que os separam. Mas, optou-se em não utiliza-lo por considerar que a Pegada Ecológica calculada nesse item seria de Palmas e não de Mateiros, apesar de saber que o aeroporto é utilizado como desembarque dos passageiros que se destinam ao Jalapão. Dessa forma, não serão considerados em Mateiros como infraestrutura de transporte para o turismo: aeroportos, portos, aeródromos, parques de estacionamentos e ferrovias, por não haverem na região ou serem pouco representativos.

Quanto às rodovias de acesso ao destino, por considerar-se que as rodovias que ligam o município às cidades circunvizinhas não foram criadas especificamente para atender o turismo, mas também para os moradores, considerou-se para fins de cálculo da Pegada Ecológica apenas as rodovias que ligam a cidade de Mateiros até os principais atrativos da cidade. Considerando ainda que alguns atrativos estão na mesma rota, fez-se a medição das estradas considerando apenas as diferenças de um atrativo ao outro. Na TAB. 5.6 dividiuse por tons da mesma cor os atrativos que ficavam na mesma rota, sendo que 0 primeiro que aparecia era acrescido às demais rotas construídas. 
Tabela 5.6: Medições das distâncias e larguras da estrada de Mateiros até os atrativos da região.

\begin{tabular}{cccc}
\hline LOCALIDADE & $\begin{array}{c}\text { Distância da cidade à } \\
\text { entrada do atrativo } \\
\text { (metros) }\end{array}$ & $\begin{array}{c}\text { Largura média da } \\
\text { estrada } \\
\text { (metros) }\end{array}$ & $\begin{array}{c}\text { Área } \\
\left(\mathrm{m}^{2}\right)\end{array}$ \\
\hline Mirante da Serra do Espírito Santo & 24840,00 & 11,06 & $274.730,40$ \\
Dunas & $+8100,00$ & 7,45 & $60.345,00$ \\
Fervedouro dos Buritis & 1990,00 & 6,50 & $12.935,00$ \\
Fervedouro do Ceiça & $+12170,00$ & 7,26 & $88.354,20$ \\
Cachoeira do Formiga & $+8010,00$ & 9,40 & $75.294,00$ \\
\hline TOTAL & $73.020,00$ & 8,33 & $511.658,60$ \\
\hline
\end{tabular}

${ }^{*}+$ = distância que foi acrescida ao trecho anterior

Como se pode notar na TAB. 5.7, tendo o valor total da infraestrutura de transporte calculada em 51,16 hectares, se dividirmos esse valor pelo número de turistas que visitaram o Jalapão no ano de 2014 que foi 8.726 tem-se o valor da Pegada Ecológica do Turismo no subitem Terras Construídas na categoria Transporte que é de 0,0058629 por turista.

Tabela 5.7: Conversão entre unidades de valores na categoria transportes

\begin{tabular}{ll|l|l}
\hline Dados & Valores em m² & Valores em ha \\
\hline $\begin{array}{l}\text { Total da área de } \\
\text { infraestrutura } \\
\text { transporte }\end{array}$ & $511.658,60$ & 51,16586 \\
de & & \\
\hline
\end{tabular}

\subsubsection{2 - Categoria Transporte - Subcategoria Terras de Energia Fóssil.}

A subcategoria terras de energia fóssil foi dividida em mais duas subcategorias, a saber: transporte aéreo e transporte terrestre. 


\subsubsection{1 - Subcategoria Terras de Energia Fóssil Transporte Aéreo}

Para analisar essa subcategoria para transporte aéreo foi necessário conhecer a estimativa de passageiros por voo com destino ao Jalapão, bem como os principais locais de origem desses passageiros para estimar a distância percorrida por voo dos passageiros e determinar a distância total voada em por passageiro-quilômetro (pkm). Para isso, foi necessário estabelecer um parâmetro para cálculo dessa subcategoria. Para se chegar a esse número buscou-se realizar entrevistas com os proprietários das pousadas e campings locais (Apêndice F). Foram entrevistados representantes dos estabelecimentos de hospedagem que ficam dentro da cidade de Mateiros. Existe apenas uma operadora de turismo que possui sede própria para acampamento, mas apesar de procurada, não concedeu a entrevista. Destes representantes de estabelecimentos hoteleiros entrevistados, somente um estabelecimento de hospedagem disse solicitar o preenchimento da Ficha Nacional de Registro de Hóspede. Nos demais estabelecimentos, não há esse controle. Dessa forma, percebeu-se a inviabilidade de se conhecer a quantidade de turistas que utilizam o transporte aéreo por esse meio. Optou-se então, em procurar as operadoras de turismo que atuam na região. Segundo a gestora da Agência de Desenvolvimento Turístico do Tocantins (ADTUR) haviam catalogadas em, 2014, cinco operadoras de turismo que realizam o translado Palmas para Mateiros. Buscou-se, então, por meio de entrevista com os representantes locais dessas operadoras, a informação sobre a quantidade de passageiros que elas teriam movimentado no ano de 2014 e que vieram de avião até Palmas. Quatro destas cinco operadoras responderam. Chegou-se, então ao número de 2.805 passageiros movimentados nesse ano, que utilizaram o avião como meio de transporte até Palmas.

Para complementar a estimativa das distâncias realizadas pelos turistas com destino ao Jalapão, tomou-se como parâmetro o total de voos que chegavam em Palmas no referido ano. Em 2014 haviam nove voos diários para Palmas. Ao multiplicar o total de voos diários por 365 dias do ano obtém-se o valor de 3.285 voos para a cidade.

Foi dividido o total de turistas que visitaram o Jalapão via transporte aéreo pelo número de voos com destino à Palmas, se tem um total de 0,853881 
passageiros por voo, pois um único avião transporta muitos passageiros que não se destinam ao Jalapão, mas à cidade de Palmas e a outras cidades da região.

Além disso, fez-se necessário conhecer os principais locais de origens dos passageiros com destino ao Jalapão. Segundo a metodologia de Feitosa e Gomez (2013), dada a inviabilidade de calcular a referida medida para todas as zonas de origem, foram estabelecidas apenas as regiões brasileiras que apresentaram maior número de turistas que desembarcaram em Palmas com destino ao Jalapão. Segundo dados coletados com os representantes das pousadas, campings e com as operadoras de turismo, as principais regiões de origem desses turistas são apresentadas na FIG. 5.38:

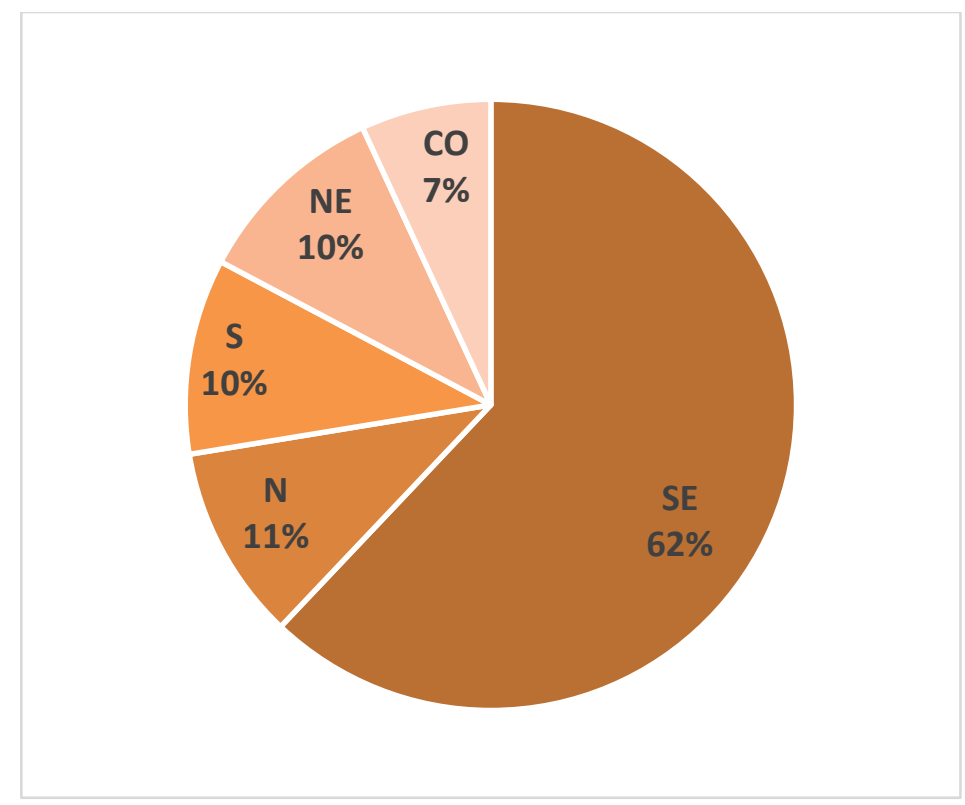

Figura 5.38: Distribuição de turistas por região

Após conhecer as principais procedências dos passageiros utilizou-se o Air Distance Calculator ${ }^{1}$ para calcular a distância em quilômetros desde a zona de origem até Palmas. Logo, são destacados os resultados na TAB. 5.8 a seguir. 
Tabela 5.8: Estimativa de distância total voada da origem à Palmas $(\mathrm{Km})$.

\begin{tabular}{l|c|c|c}
\hline \multicolumn{1}{c|}{ Origem } & Distância & Proporção & $\begin{array}{c}\text { Distância voada para } \\
\text { média ponderada }\end{array}$ \\
\hline Sudeste & 1.492 & 18 & 26.856 \\
\hline Nordeste & 2.334 & 3 & 7.002 \\
\hline Centro-oeste & 623 & 2 & 1.246 \\
\hline Sul Total & 1.932 & 3 & 5.796 \\
\hline \multicolumn{1}{c|}{} & 26 & 40.900 \\
\hline Média Ponderada & 6.381 & \multicolumn{2}{c}{$1.573,077$} \\
\hline
\end{tabular}

Dando continuidade à análise, calculou-se a distância total voada por passageiro-quilômetro $(\mathrm{pkm})$, sendo a distância total por voo obtida ao se multiplicar por dois a média ponderada final da TAB. 5.8, considerando-se que em uma viagem aérea tem-se a ida e a volta para origem. Além disso, considera-se que para se obter a distância total voada (em pkm) deve-se multiplicar a distância total por voo $(\mathrm{em} \mathrm{km})$ pelo número de turistas que visitaram o Jalapão via transporte aéreo. Os resultados podem ser visto na TAB. 5.9:

Tabela 5.9: Distância total voada por passageiro-quilômetro para Palmas

\begin{tabular}{c|c|c}
\hline Distância total por voo em Km & Número de turistas/voo & Distância total voada (em pkm) \\
\hline $3.146,15$ & 0,853881 & $2.686,44$ \\
\hline
\end{tabular}

De acordo com a metodologia proposta por Gössling et al. (2002) para fins de cálculo das terras de energia fóssil relativas aos transportes aéreos, deve-se multiplicar o valor obtido na distância total voada $(\mathrm{pkm})$ pelo fator de intensidade energética $(2 \mathrm{MJ} / \mathrm{pkm})$ para obter o consumo energético do voo. Dessa forma, chegou-se ao valor de 5372,88 MJ/pkm. Esse por sua vez, deve ser convertido para GJ, cujo valor encontrado foi 5,37 GJ, considerando que $1 \mathrm{GJ}=1.000 \mathrm{MJ}$. Na sequência deve se dividir o consumo energético do voo (GJ) pelo total de passageiros para identificar o consumo energético per capita, bem como dividir o consumo energético per capita (GJ/cap) por $73 \mathrm{Gj} / \mathrm{ha} / \mathrm{yr}$, onde yr significa ano, para determinar a quantidade de terra de energia fóssil demandada per capita (ha/cap); e por fim, estimar novamente a terra de energia fóssil requerida por passageiro, multiplicando-se o resultado do item anterior pelo fator de correção para grandes altitudes, isto é, 2,7 (Gössling et al., 2002). Os resultados são apresentados na TAB. 5.10: 
Tabela 5.10: Resumo dos cálculos categoria transporte aéreo: terras de energia fóssil

\begin{tabular}{|c|c|c|c|}
\hline & Item & Cálculo & Valores \\
\hline 1 & $\begin{array}{l}\text { Total de turista que vão de avião para o } \\
\text { Jalapão/ano }\end{array}$ & - & 2.805 \\
\hline 2 & Total de voos diários $=9$ & $9 \times 365$ dias & 3.285 \\
\hline 3 & Passageiros por voo & Item 1 / Item 2 & 0,853881279 \\
\hline 4 & Distância por voo (km) & $\begin{array}{c}\text { Média ponderada principais } \\
\text { destinos } 1.573,077 \text { × } 2 \text { (ida e } \\
\text { volta }\end{array}$ & $3.146,15$ \\
\hline 5 & Distância voada * total de passageiros (pkm) & Item $3 \times$ Item 4 & $2.686,44$ \\
\hline 6 & Consumo energético do voo & Item $5 \times 2$ & $5.372,88$ \\
\hline 7 & Consumo em GJ & Item $6 / 1.000$ & 5,37 \\
\hline 8 & Consumo per capta & Item $7 / 100$ * Item 3 & 0,0459 \\
\hline 9 & $\begin{array}{l}\text { Quantidade de terra de energia fóssil } \\
\text { demandada per capita (ha/cap) }\end{array}$ & Item 8 / 73 & 0,00063 \\
\hline 10 & $\begin{array}{l}\text { Terra de energia fóssil requerida por } \\
\text { passageiro }\end{array}$ & Item $9 \times 2,7$ & 0,00170 \\
\hline 11 & $\begin{array}{l}\text { Terra de energia fóssil requerida por todos } \\
\text { passageiros/ano }\end{array}$ & Item $10 \times$ Item 1 & 4,7685 \\
\hline
\end{tabular}

Dessa forma, foram necessários 4,7685 hectares demandadas para a utilização do transporte aéreo de turistas com destino ao Jalapão.

\subsubsection{2 - Subcategoria Terras de Energia Fóssil Transporte Terrestre}

Para fins de se calcular as terras de energia fóssil para a subcategoria transporte terrestre foi necessário conhecer o total de turistas que visitaram 0 Jalapão. Como os turistas que veem via transporte aéreo também precisam se deslocar de Palmas para Mateiros via terrestre; considerou-se o total de 8.726 turistas que visitaram o Jalapão no ano de 2014, conforme dados da NATURATINS discutidos anteriormente neste trabalho.

Além disso, precisou-se conhecer o total de litros de combustível demandados por viagem de ida e volta por Palmas. Levando-se em consideração que um carro com tração, que são os veículos mais utilizados na região devido as condições da estrada, faz em média $6 \mathrm{~km} / \mathrm{l}$ de gasolina em um total de $800 \mathrm{~km}$ ida e volta, tem-se um média de 133,3 litros de combustível utilizados para uma viagem ida e volta para o Jalapão.

Seguindo-se ainda a metodologia utilizada, 1 litro de gasolina queimado libera 2,63 kg de $\mathrm{CO}_{2}$ e $1000 \mathrm{~kg}$ corresponde a 1 tonelada, obteve-se o total de toneladas de $\mathrm{CO}_{2}$ emitidos na viagem para o Jalapão quando se multiplicou o total de litros consumidos por 2,63 e dividiu-se o resultado por 1000. O valor encontrado foi o de 0,350579, mas sabendo-se que cada carro leva em média 3 
turistas, foi necessário dividi-lo pela média de turista por carro. Logo, o valor foi 0,116860. Segundo Feitosa e Gomez (2012) ao se considerar que conforme dados do Painel Intergovernamental de Mudanças Climáticas (Intergovernmental Panel on Climate Change - IPCC) para cada 1 tonelada de $\mathrm{CO}_{2}$ emitida é necessário 1 hectare de área para sua absorção, a área necessária para absorver o $\mathrm{CO}_{2}$ emitido por turista é de 0,116860 ha. O valor total de área demanda para a categoria terras de energia fóssil, subcategoria transporte terrestre foi de 1019,71745 ha, a se multiplicar o valor por turista pelo número total de turistas que visitaram o Jalapão em 2014 (8726). A seguir, apresenta-se a TAB. 5.11 com o demonstrativo dos cálculos:

Tabela 5.11: Resumo dos cálculos categoria transporte terrestre: terras de energia fóssil

\begin{tabular}{c|l|l|r}
\hline & \multicolumn{1}{|c|}{ Item } & \multicolumn{1}{c}{ Cálculo } & Valores \\
\hline 1 & Total de turistas & - & 8.726 \\
\hline 2 & $\begin{array}{l}\text { Total de litros de combustível por viagem ida } \\
\text { e volta para Palmas }\end{array}$ & $880 \mathrm{~km}$ dividido 6 km/litro & 133,3 \\
\hline 3 & $\begin{array}{l}\text { Total de toneladas emitidas de } \mathrm{CO}^{2} \text { por } \\
\text { viagem }\end{array}$ & Item 2 x 2,63 / 1000 & 0,350579 \\
\hline & $\begin{array}{l}\text { Total de toneladas emitidas de CO² por } \\
\text { viagem por turista (Média 3 por carro) }\end{array}$ & Item 3 dividido 3 & 0,116859667 \\
\hline 5 & $\begin{array}{l}\text { Área necessária para absorver CO² emitido } \\
\text { (ha) por turista }\end{array}$ & Item 4 & 0,11686 \\
\hline 6 & $\begin{array}{l}\text { Área necessária para absorver } \mathrm{CO}^{2} \text { emitido } \\
\text { (ha) por todos os turistas no ano }\end{array}$ & Item 4 x item 1 & $1.019,71745$ \\
\hline 7 & $\begin{array}{l}\text { Terra de energia fóssil requerida por todos } \\
\text { passageiros/ano (ha/ano) }\end{array}$ & \multicolumn{2}{|c}{$1.019,7174$} \\
\hline
\end{tabular}

\subsection{2 - Categoria Água}

Tal como foi discutido anteriormente, Mateiros é uma cidade que possui um sistema de abastecimento de água precário. Com o aumento no número de visitantes na cidade há um agravamento ainda maior da precariedade em que já padece.

Para o cálculo da área de terras de energia fóssil dessa categoria considera-se que no processo de tratamento, encanação e distribuição de um megalitro ( $\mathrm{ML}$ ) de água é liberado 0,37 tonelada de dióxido de carbono. Precisou-se então identificar, em uma primeira etapa, o total de água consumida (em $\mathrm{mgl}$ ) pelos turistas em Mateiros. Após isso, esse consumo foi convertido em 
toneladas de $\mathrm{CO}_{2}$, que por sua vez foram convertidos em hectares de terras de energia fóssil, por considerar que uma tonelada de dióxido de carbono equivale a um hectare de terra (FEITOSA e GOMEZ, 2013).

Considerando-se que pela metodologia proposta o consumo médio diário de água por leito é 120 litros por hóspede, sendo 1 metro cúbico igual a 1000 litros de água, que daria um total de $0,12 \mathrm{~m}^{3}$, além disso, se faz necessário converter para megalitro o valor acima que daria o total de 0,00012ML. Outro dado importante para o referido cálculo é o número de turistas que visitaram Mateiros (valor já descrito anteriormente como sendo 8.726 visitantes) e a média de dias que estes permaneceram no local (3 dias).

Dessa forma, tendo como estimativa que um turista consumiu 0,00036ML de água em sua estadia em Mateiros (0,00012 ML x 3 dias), multiplicou-se pelo número total de turistas que visitaram o Jalapão (8.726 turistas) chegando ao número de 3,14136 megalitros. Para se transformar esse valor em toneladas de $\mathrm{CO}_{2}$ em hectares, segundo a metodologia proposta, deve-se multiplicar o resultado em $\mathrm{ML}$ por 0,37t que daria um resultado de 1,162303 hectares necessários para compensar a emissão desse gás anualmente. A TAB. 5.12 descreve os cálculos realizados nessa categoria:

Tabela 5.12: Resumo dos cálculos categoria água

\begin{tabular}{c|l|c|c}
\hline & Item & Cálculo & Valores \\
\hline 1 & Consumo de água por leito/dia (litros) & - & 120 \\
\hline 2 & Consumo de água por leito/dia $\left(\mathrm{m}^{3}\right)$ & Item 1/1000 & 0,12 \\
\hline 3 & $\begin{array}{l}\text { Consumo de água por leito, por dia, em } \\
\text { megalitro }\end{array}$ & Item 2/ 1000 & 0,00012 \\
\hline & & - & 3 \\
4 & Número médio de dias de hospedagem & - & 8726 \\
\hline 5 & Número de turistas & Item 3 x item 4 x item 5 & 3,14136 \\
\hline 6 & Consumo total de água no ano & Item $6 \times 0,37$ & 1,162303 \\
\hline 7 & Total de CO2 emitido & \multicolumn{2}{|c}{1,1623} \\
\hline 8 & Total de hectares necessários & \multicolumn{2}{|c}{} \\
\hline
\end{tabular}

A liberação de $\mathrm{CO}_{2}$ ocorre na etapa do tratamento da água. Como no ano de estudo deste trabalho não havia tratamento da água ainda, optou-se por não considera-la no somatório final da Pegada Ecológica do Turismo na cidade de Mateiros. Desta forma, calculou-se esta categoria para fins de conhecimento dos 
possíveis impactos ambientais que podem surgir após o tratamento da água que se iniciou em meados de 2015.

\subsection{3 - Categoria - Resíduos Sólidos}

Um dos impactos sociais e ambientais com maior significado para um destino turístico é sem dúvida a falta de gestão dos resíduos sólidos. Isso pode elevar consideravelmente a pegada ecológica de qualquer ecossistema. A região do Jalapão não possui uma estação de tratamento de resíduos sólidos e seu armazenamento ocorre em "lixões a céu aberto". Isso já implica em impactos ambientais na localidade.

Para a realização do cálculo desse item, foi necessário estimar o volume diário de resíduos em quilogramas produzidos por cada turista, a média de dias que esses ficavam na localidade e o total de turistas que visitaram a localidade no ano escolhido para realização da pesquisa.

Como não há estimativa do volume produzido por habitante na localidade, optou-se em calcular pela média gerada no Brasil de $1,5 \mathrm{~kg}$ de resíduos sólidos/dia. Tendo-se, então, 8.726 turistas visitando o Jalapão no ano de estudo, com um média de estadia de 3 dias, chegou ao total de que cada turista gerou 4,5 kg em sua estadia no município (1,5 x 3 dias) e 39.267 kg de resíduos sólidos ou 39,267 toneladas (39.267 kg / 1000). Converte-se esse valor em toneladas de $\mathrm{CO}_{2}$, que segundo Wackernagel e Rees (FEITOSA e GOMES, 2012), 0,00135T de resíduos equivale a 0,00045 toneladas de $\mathrm{CO}_{2}$, desse modo tem-se o valor de 13,089 toneladas desse gás em Mateiros (39,267 x 0,00045 / 0,00135). Logo, seguindo os parâmetros dos referidos autores, 1 tonelada de $\mathrm{CO}_{2}$ é assimilada por 1 hectare de terra, serão necessários em Mateiros 13,089 hectares de terras para assimilar o gás carbônico produzido.

Feitosa e Gomes (2012) ainda destacam que os resíduos sólidos também produzem o gás metano $\left(\mathrm{CH}_{4}\right)$ que também são absorvidos pelas florestas e para se realizar o cálculo preciso da pegada ecológica se faz necessário multiplicar o total de hectares requeridos para absorver $\mathrm{O}^{\mathrm{CO}_{2}}$ por dois, por considerar que $\mathrm{o}$ metano detém as mesmas características que o gás carbônico. Logo, demandouse 26,178 hectares de terra $(13,089 \times 2)$ para absorver o $\mathrm{CO}_{2}$ e o $\mathrm{CH}_{4}$ decorrentes 
dos resíduos sólidos gerados pelos turistas em Mateiros/Jalapão, conforme é demonstrado na TAB. 5.12, que descreve os cálculos realizados nessa categoria:

Tabela 5.13: Resumo dos cálculos categoria resíduos sólidos

\begin{tabular}{|c|c|c|c|}
\hline & Item & Cálculo & Valores \\
\hline 1 & $\begin{array}{l}\text { Resíduos sólidos produzidos por dia/turista } \\
(\mathrm{Kg})\end{array}$ & (2). & 1,5 \\
\hline 2 & Número de dias de permanência/turista & - & 3 \\
\hline 3 & Número de turistas / ano & - & 8.726 \\
\hline 4 & $\begin{array}{l}\text { Resíduos sólidos produzidos por turista em } 3 \\
\text { dias }(\mathrm{Kg})\end{array}$ & Item 1 x Item 2 & 4,5 \\
\hline 5 & $\begin{array}{l}\text { Resíduos sólidos produzidos por todos os } \\
\text { turistas / ano }(\mathrm{Kg})\end{array}$ & Item $3 \times$ Item 4 & 39.267 \\
\hline 6 & $\begin{array}{l}\text { Resíduos sólidos produzidos por todos os } \\
\text { turistas / ano (t) }\end{array}$ & Item $5 / 1000$ & 39,267 \\
\hline 7 & $\mathrm{CO}_{2}$ produzidos por todos os turistas / ano (t) & Item $6 \times 0,00045 / 0,00135$ & 13,089 \\
\hline 8 & $\mathrm{CH}_{4}$ produzido juntamente com $\mathrm{CO} 2(\mathrm{t})$ & Item $7 \times 2$ & 26,178 \\
\hline 9 & Hectares necessários & 26,178 & \\
\hline
\end{tabular}

\subsection{4 - Categoria - Alojamento}

Nessa categoria há uma subdivisão em dois tipos de terras associadas: terras construídas e as terras de energia fóssil para que se possa verificar a influência que as pousadas provocaram no ecossistema natural de Mateiros/TO.

\subsubsection{1 - Categoria - Alojamento - Terras construídas}

Para o cálculo das terras construídas, iniciou-se o cálculo obtendo-se o número de pousadas, hotéis e leitos da localidade, bem como, o número de turistas que lá passaram no ano escolhido para o estudo. Já para o cálculo das terras de energia fóssil utilizou-se o quantitativo de hospedarias e leitos existentes na cidade, a estimativa do total de energia que cada pousada consumiu, o número de turistas que lá visitaram e o número médio de pernoites na cidade.

$\mathrm{Na}$ cidade de Mateiros não há nenhum hotel que seja oficialmente classificado pelos critérios exigidos pelo Ministério do Turismo, baseado nas entrevistas realizadas com representantes dos empreendimentos hoteleiros da 
cidade de Mateiros. Para fins do cálculo da pegada ecológica, foi realizada a categorização considerando a seguinte classificação dos meios de hospedagens:

Pousada: Empreendimento de característica horizontal, composto de no máximo 30 unidades habitacionais e 90 leitos, com serviços de recepção, alimentação e alojamento temporário, podendo ser em um prédio único com até três pavimentos, ou contar com chalés ou bangalôs (MTUR, 2016).

Como não há nenhum hotel que possua mais de 90 leitos em Mateiros, de acordo com pesquisa realizada com os proprietários das pousadas de Mateiros, todos os empreendimentos hoteleiros foram classificados como sendo pousadas. Dessa forma, considera-se o quantitativo de $60 \mathrm{~m}^{2}$ necessários por leito. Há um total de sete pousadas em Mateiros, que conjuntamente totalizam 220 leitos na cidade. Ao multiplicar-se o total de leitos na cidade pelo quantitativo de $\mathrm{m}^{2}$ requeridos por leito, tem-se o valor de $13.200 \mathrm{~m}^{2}$ de área de terras construídas. Se um hectare é igual a $10.000 \mathrm{~m}^{2}$, tem-se o valor de 1,32 hectares de terras construídas. Resumo das análises pode ser vista na TAB. 5.13:

Tabela 5.14: Resumo dos cálculos categoria alojamentos: terras construídas

\begin{tabular}{l|l|c|c}
\hline & Item & Cálculo & Valores \\
\hline 1 & Área requerida por leito $(\mathrm{m} 2)$ & - & 60 \\
\hline 2 & Total de leitos disponíveis & - & 220 \\
\hline 3 & Total de área requerida (m2) & Item 1 $\mathrm{x}$ item 2 & 13200 \\
\hline & & & \\
4 & Total de área requerida (ha) & Item 3 / 10000 & 1,32 \\
\hline 5 & Hectares necessários & \multicolumn{2}{c}{1,32} \\
\hline
\end{tabular}

\subsubsection{2 - Categoria - Alojamento - Terras de energia fóssil}

Quanto à categoria de terras de energia fóssil demandadas para absorver o $\mathrm{CO}_{2}$ emitido pela produção de energia elétrica das acomodações de turismo, considerando que o consumo de energia em um leito é de $130 \mathrm{MJ} /$ leito/noite em alojamentos da hotelaria tradicional, segundo Feitosa e Gomez (2012), e a permanência média dos turistas que visitam o Jalapão foram três dias, foi possível 
obter o consumo de energia atribuível ao turismo em Mateiros em 2014 como sendo $390 \mathrm{MJ} /$ leito (130MJ/leito/noite x 3 noites). Para se obter a estimativa de consumo de energia elétrica no ano, multiplicou-se esse valor pelos 8.726 turistas que visitaram o Jalapão em 2014, cujo valor foi de 3.403.140MJ. Foi necessário a conversão dos valores em MJ para GJ para fins de cálculo das terras de energia fóssil. Para tanto, foram necessários 3.403,143 GJ para atender as necessidades demandadas pela atividade de turismo. Precisou-se dividir o consumo energético per capita (GJ) por $73 \mathrm{GJ} / \mathrm{Ha} / \mathrm{Yr}$ para determinar a quantidade de terras de energia fóssil demandada. Obteve-se o valor de 46,61839 ha de terra de energia fóssil que a atividade turística de Mateiros consumiu como um todo para assimilar todo o dióxido de carbono lançado na atmosfera. A TAB. 5.14 descreve o resumo dos cálculos.

Tabela 5.15: Resumo dos cálculos categoria alojamentos: terras de energia fóssil

\begin{tabular}{c|l|c|c}
\hline & Item & Cálculo & Valores \\
\hline 1 & Energia consumida por leito/dia (MJ) & - & 130 \\
\hline 2 & Turistas /ano & - & 8.726 \\
\hline 3 & Número de dias estadia & & 3 \\
\hline & & & \\
4 & Consumo de Energia Elétrica em 1 ano (MJ) & Item 1 x item 2 x item 3 & 3403140 \\
\hline 5 & Consumo de Energia Elétrica em 1 ano GJ & Item 4 x 1000 & $3.403,140$ \\
\hline 6 & Converter GJ para há & Item 5 /73 & 46,61839 \\
\hline 7 & Hectares necessários & \multicolumn{2}{|c}{46,61839} \\
\hline
\end{tabular}

\subsection{5 - Categoria - Atividades de lazer}

Para fins do cálculo da pegada ecológica para a categoria atividades de lazer, que tem com principal objetivo a análise das terras construídas necessárias para satisfazer as necessidades da atividade turística, foi necessária a estimativa do quantitativo de turistas que visitaram a cidade, que no caso, sabe-se que foram 8.726 no ano proposto para o estudo. Além disso, foi realizado o cálculo das áreas construídas em atrativos turísticos mais visitados de Mateiros. Para obterse esses valores foram feitas as medições dos principais atrativos e os valores estão dispostos na TAB. 5.15 a seguir: 
Tabela 5.16: Áreas construídas nos atrativos turísticos:

\begin{tabular}{|c|c|c|c|}
\hline Localidade & $\begin{array}{c}\text { Da estrada } \\
\text { ao atrativo } \\
\left(\mathrm{em} \mathrm{m}^{2}\right) \text { : }\end{array}$ & $\begin{array}{l}\text { Atrativo em si } \\
\quad\left(\mathrm{em} \mathrm{m}^{2}\right)\end{array}$ & $\begin{array}{c}\text { Área total } \\
\text { construída (em } \\
\left.\mathrm{m}^{2}\right)\end{array}$ \\
\hline Dunas & $91.885,7$ & 805,7 & $92.691,4$ \\
\hline Fervedouro Ceiça & $1.332,0$ & 815,0 & 2.147 \\
\hline Serra E. Santo & $2.904,0$ & $3.177,5$ & $6.200,5$ \\
\hline Formiga & $58.590,0$ & 731,3 & $59.321,3$ \\
\hline \multicolumn{3}{|c|}{ Total de área construída } & $160.360,2$ \\
\hline
\end{tabular}

Constatou-se, então, que a área construída total dos atrativos turísticos era de $160.360,2 \mathrm{~m}^{2}$ ou 16,03602 hectares de terras construídas.

Logo, foram demandadas 16,03602 hectares de terras construídas para visitar-se o Jalapão nesse ano. Deve-se destacar que essa estrutura tende a aumentar a cada ano que se passa, pois o número de turistas está crescendo. Impactos ambientais são percebidos, como já foi discutido anteriormente neste trabalho.

\subsection{6 - Categoria - Alimentação e consumo de fibras}

Para fins de cálculo da categoria alimentação e consumo de fibras, Gössling et al. (2002) consideraram que os turistas em um destino turístico consomem os mesmos tipos de alimentos e fibras disponíveis no seu local de origem. Mas, como na cidade de Mateiros não há infraestrutura de alimentação de médio porte, pelo menos, onde seria possível uma variação alimentar na qual se refere a metodologia proposta para alimentação e consumo de fibras, tal categoria será considerada tendo como base a alimentação de acordo com os parâmetros locais, isto é, o consumo de fibras no Brasil.

Foi necessário conhecer a pegada média de alimentação e consumo de fibras do Brasil, que segundo o Relatório Planeta Vivo (WWF, 2012) é de 2,35 hectares de terra, considerando agricultura, pasto, floresta e área de pesca. Precisou-se calcular a pegada ecológica do consumo de alimentos e fibras referente ao período em que o turista esteve no Jalapão. Logo, dividiu-se o valor encontrado da pegada média de alimentação e consumo de fibras por 365 dias (2,35 / 365 dias) obtendo-se o valor de 0,006438. Esse valor se multiplicado pela estadia média que os turistas permanecem no Jalapão (3 dias) daria o valor de 
0,01931, que foi multiplicado pelo total de turistas que visitaram a região nesse período que foi 8726 , totalizando 168,542 hectares de terras bioprodutivas.

\subsection{7 - Pegada Ecológica do Turismo de Mateiros}

Após os cálculos de cada categoria foi realizado o somatório destes componentes, de acordo com a metodologia proposta, para que se conhecesse a pegada ecológica do turismo final de Mateiros.

Foi necessário o somatório das Terras de Energia Fóssil de cada categoria, a saber: terra de energia fóssil dos transportes aéreo (4,7596 ha), terra de energia fóssil dos transportes terrestres $(1.019,7174 \mathrm{ha})$, terra de energia de fóssil das acomodações (46,6183 ha) e terra de energia fóssil dos resíduos sólidos (26,178 ha). Não serão somadas as terras de energia fóssil da água (1,1623 ha). Desta forma, para essa categoria foram demandadas 1.097,2733 hectares de terras.

Da mesma forma, foi calculada a Pegada Ecológica de Terras Construídas que deveria considerar no caso do objeto de estudo apenas as terras construídas pelas acomodações (1,32 ha), terras construídas pelas rodovias (50,47 ha) e área de terra construída pelos atrativos turísticos $(16,03602$ ha) cujo somatório foi de 67,82602 hectares demandadas pela categoria.

Como para a categoria de Terras Bioprodutivas foi obtido o valor de 168,542 hectares, deu-se sequência ao cálculo da pegada ecológica. Foi seguida a proposta da metodologia que previa a multiplicação dos fatores de equivalência. Logo, na categoria de Terras de Energia Fóssil (1097,2733 ha) deveria se multiplicar por 1,8 , cujo resultado foi $1.975,0919$ ha e a categoria de Terras Construídas (67,82602 ha) multiplicou-se por 3,2 que gerou o total de 217,04326 ha, que, depois de somados os valores das terras construídas, das terras de energia fóssil e das terras bioprodutivas, chegou-se à Pegada Ecológica do Turismo de Mateiros de 2.361,606 hectares de terras demandadas para as necessidade requeridas pela atividade turística na região.

A categoria com maior impacto foi das terras de energia fóssil na subcategoria transporte terrestre. Acredita-se que esse número elevado se deve 
aos $800 \mathrm{~km}$ necessários para se locomover até Mateiros, sem levar em consideração as precárias condições das estradas dos principais acessos à Mateiros que aumentam o tempo da viagem e o consumo em algumas situações nas estradas. 


\section{6 - CONCLUSÃO}

No que se refere aos indicadores da ONU conclui-se que eles não devem ser utilizados em destinos de pequeno porte que se assemelhem à cidade de Mateiros, por meio de pesquisa com dados secundários ou primários da forma que foram realizadas a presente pesquisa. Acredita-se que a coleta de dados para este indicador não foi adequado. Sugere-se que seja utilizado desde que não se baseiem exclusivamente em dados secundários ou entrevistas com gestores, mas que se possam utilizar instrumentos de coleta de dados que permitam apresentar resultados mais precisos que a ferramenta exige. Nestas cidades de pequeno porte quase sempre não há sistematização de dados suficientes para que a ferramenta proposta pela ONU possa ser utilizada pelos órgãos governamentais na captação de recursos e utilização destes para criar novas políticas públicas para a região.

Ao mesmo tempo, os indicadores da ONU mostraram que há uma infinidade de outros trabalhos que podem ser desenvolvidos, para auxiliarem na elaboração de políticas públicas, trazendo benefícios para a região, tais como os que serão apresentados ao final deste trabalho.

Quanto à ferramenta de pesquisa "Índice de Qualidade de Vida" da população de Mateiros, se mostrou eficaz quanto à sua aplicabilidade em destinos de pequeno porte. O IQV no município de Mateiros ainda é considerado baixo. Isso se deve basicamente às condições de saúde, educação e comunicação e lazer que a comunidade possui. Ainda assim, mesmo com um baixo índice de qualidade de vida, a cidade de Mateiros demonstrou por meio das narrativas orais que se mantém satisfeita com suas condições de vida, apesar de reconhecerem que muito deve ser feito em todas as esferas dos indicadores propostos, dando ênfase para aspectos sanitários, de saúde e de educação conforme relatos de moradores. 
Quanto à Pegada Ecológica do Turismo, como foi apresentado no capítulo anterior, foi considerada alta, pois ao se somar o total de hectares necessários anualmente para que a atividade turística aconteça, tem-se um valor de 2.194,2263 hectares necessários para absorver o $\mathrm{CO}_{2}$. Quando comparado esse valor com o valor total do município, que é, segundo dados do IBGE 969.125,5 é considerado pequeno, mas se comparado a área do Parque Estadual do Jalapão, que é 158.000 hectares (GESTO, 2016) e que detém os maiores atrativos turísticos da localidade, pode ser considerado alto, pois mantida essa emissão, teremos, ao final de 10 anos, um total de 21.000 hectares necessários para que a atividade turística seja mantida. Isso representa mais de $13 \%$ da área total do parque.

Ao se comparar o Índice de Qualidade de Vida com a pegada ecológica do turismo de Mateiros foi possível constatar que os impactos ambientais são reais, mas ao mesmo tempo a comunidade tem no turismo uma fonte de renda ou um complemento desta, pois houve um ganho na qualidade de vida da população com o advento do turismo na região, mediante a análise do IQV e das narrativas orais. Por consequência, seria o caso de apoiar o incentivo do turismo na região. Dessa forma, sugere-se nesse trabalho que, para minimizar os impactos ambientais trazidos pelas atividades de turismo, a região de Mateiros possa se tornar referência em turismo ambientalmente sustentável, no que se refere à busca de energias alternativas, melhoria das estradas, implantação de um adequado gestão de resíduos sólidos e até na implantação de uma infraestrutura aeroportuária para receber turistas oriundos das mais diversas localidades do Brasil e do mundo, evitando-se assim que haja a necessidade de traslado de Palmas para Mateiros em todas as viagens turísticas.

Ao mesmo tempo, há de se pensar que o aumento do turismo na região deve estar atrelado à melhoria das condições de hospitalidade turística na região, com investimentos na rede hoteleira e em bares e restaurantes. Mais cursos devem ser pensados para a região para que a população se perceba como potenciais empreendedores e possam melhorar a sua qualidade de vida, e ao mesmo tempo, melhorando os serviços turísticos ofertados na região do Jalapão. 
Conclui-se ainda que os dois indicadores de sustentabilidade: a Pegada Ecológica do Turismo e o Índice de Qualidade de Vida mostraram-se ferramentas eficazes para se avaliar as perspectivas de sustentabilidade de destinos de pequeno porte, podendo assim ser utilizadas como ferramenta para pesquisa em destino com essas mesmas características. Sugere-se, para aprimorar a análise, que seja ajustado o indicador sobre educação, inserindo-se variáveis agrupadas para as respostas às perguntas sobre escolaridade do entrevistado e quantos filhos estudam. Da mesma forma, que sejam melhor agrupadas as respostas à pergunta sobre o grau de instrução dos filhos.

Ao final, acredita-se que esses dados servirão para que tanto os gestores públicos quanto a cidade de Mateiros possam implementar ou cobrar por políticas públicas que possam selecionar área prioritárias dentre as apresentadas nesse trabalho para que se invista na qualidade de vida da população local. Além disso, o trabalho permitirá que se fortaleçam a sustentabilidade local do turismo, buscando investimentos em turismo sustentável nessa região abundantemente rica em biodiversidade e cultura. 


\section{7 - ESTUDOS FUTUROS}

Ao final deste estudo alguns estudos são recomendados para que se dê continuidade à pesquisa, são eles:

- Pesquisas na área ambiental:

- Quantidade emitida de gases que contribuem para o efeito estufa;

- Estudo das áreas protegidas de cerrado;

- Levantamento sobre a captura anual de espécies de maior interesse comercial;

- Estudos sobre a água utilizada pela população;

- Educação ambiental para moradores que atuem com turismo, bem como, com crianças da cidade de Mateiros;

- A pegada ecológica do turismo após a implantação do tratamento, encanação e distribuição de água, dentre outros.

- Pesquisa na área econômica:

- Levantamento sobre crescimento econômico;

- Estudo sobre o uso de energia;

- Estudo sobre o gerenciamento de efluentes, dentre outros.

- Pesquisa na área social:

- Estudo sobre a porcentagem da população vivendo abaixo da linha da pobreza;

- Estudo sobre taxa de desemprego;

- Comparativo sobre salário entre gêneros;

- Status nutricional das crianças;

- Percentagem da população com acesso as unidade de atenção primária à saúde;

- Estudo sobre o nível de educação média entre adultos;

- Capacitação com moradores que atuam com turismo, tais como, sobre hospitalidade, boas práticas à mesa, empreendedorismo, dentre outros. 


\section{APÊNDICE A - Questionário Indicadores Ambientais ONU}

\section{ipen}

Doutorado em Ciências IPEN/USP

\section{Questionário INDICADORES AMBIENTAIS}

Respondam as perguntas abaixo, por favor, levando em consideração especificamente a realidade da região de Mateiros/TO.

1- Qual a quantidade volumétrica de emissão de gases que contribuem para o efeito estufa?

2- Qual a área de cultura agrícola permanente e de terras agricultáveis?

3- Qual a quantidade em toneladas de uso de fertilizantes e uso de agrotóxicos?

4- Quais são os tamanhos das áreas permanentes de cerrado na região de Mateiros, incluindo área do PEJ? 
5- Qual o tamanho de Área desertificada na região?

6- No que tange área de urbanização existe alguma área ocupada irregularmente?

7- Há algum estudo feito na região que indicou a concentração de algas em águas de rio que abastecem a cidade ou que formam algum atrativo turístico da região?

8- Qual a porcentagem da população total vivendo em zonas ribeirinhas?

9- Há algum levantamento que mostre o número de captura anual de espécies de maior interesse comercial? 
10- Como é feito o fornecimento de água na região? Há um percentual de fornecimento anual de água subterrânea e de superfície por disponibilidade anual?

11- Foi realizado algum estudo sobre a qualidade da água disponibilizada à população? Se sim, poderia apontar o estudo ou os principais resultados quanto à demanda bioquímica por oxigênio em corpos d'água?

12- Há áreas protegidas na região? Se sim, qual o tamanho dessas áreas protegidas?

13- Qual a porcentagem de área protegida por área total do município?

14- Qual a abundancia das espécies encontradas na região protegidas? 
15-Quais atrativos turísticos estão hoje dentro da área do Parque Estadual do Jalapão? E quais desses são administrados por proprietários particulares das áreas? 


\section{APÊNDICE B - Questionário Indicadores Econômicos ONU}

\section{ipen}

Doutorado em Ciências IPEN/USP

\section{Questionário INDICADORES ECONÔMICOS}

Respondam as perguntas abaixo, por favor, levando em consideração especificamente a realidade da região de Mateiros/TO.

1- Existe algum estudo que aponte o saldo da balança comercial? Se sim, qual é o valor?

2- Qual o Produto Interno Bruto (PIB) per capita do município?

3- Existe investimento em ações na forma do PIB? Quanto seria esse investimento e como ele é feito?

4- Qual a razão da dívida externa pelo PIB da cidade? 
5- Existe algum estudo relacionado ao consumo de matérias primas? Qual a intensidade desse consumo?

6- Qual o consumo anual, per capita, de energia?

7- Existe algum investimento em ações de energia renováveis e não renováveis? Qual seria o valor desses investimentos e quais seriam esses projetos?

8- Qual a intensidade do uso de energia?

9- Há um gerenciamento do lixo industrial e outros resíduos urbanos? Como se dá esse gerenciamento? 
10- Quanto de lixo perigoso se é gerado mensalmente? 


\section{APÊNDICE C - Questionário Indicadores Sociais ONU}

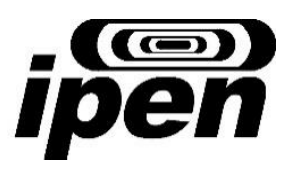

Doutorado em Ciências IPEN/USP

\section{Questionário INDICADORES SOCIAIS}

Respondam as perguntas abaixo, por favor, levando em consideração especificamente a realidade da região de Mateiros/TO.

1- Existe algum estudo que aponte o percentual da população vivendo abaixo da linha da pobreza? Se sim, qual é o valor?

2- Qual a taxa de desemprego no município?

3- Há algum estudo que demonstrem se há diferença entre o salário médio feminino e masculino?

4- Há levantamentos que apontem o status nutricional das crianças? 
5- Qual o coeficiente de mortalidade anual de crianças até cinco anos de idade no município?

6- Qual a expectativa de vida média da população?

7- Quantas residências são atendidas pelo serviço de esgoto sanitário em Mateiros? Há algum investimento por vir nessa área? Se sim, qual?

8- Há estação de tratamento de água na cidade? Em caso positivo, quantas casas são atendidas? Caso negativo, qual método alternativo?

9- Qual o número de atendimentos nas unidades de atenção primária à saúde? Como ocorre esse atendimento? 
10- Qual o percentual de crianças anualmente (2012, 2013 e 2014) imunizadas contra doenças infecciosas infantis?

11- Há algum estudo que aponte o número de mulheres que fazem uso de métodos contraceptivos?

12-Qual a porcentagem das crianças fora da escola fundamental?

13- Qual o percentual de jovens atendidos na educação média no município?

14- Qual a taxa de analfabetismo de adultos?

15- Qual o número médio de filhos por família e qual a área média construída por moradia? 
16- Qual o número de crimes registrados por ano (2012 / 2013 e 2014) no município? A cidade dispõe de delegacia? Se não, como são feitos esses registros?

17-Qual a taxa de crescimento da população nos últimos anos?

18-Qual a população urbana morando em moradias formalmente regulares e irregulares na cidade?

19- Qual o número de residências habitadas na região? 


\section{APÊNDICE D - Questionário para entrevista por residência IQV}

\section{ipen}

Doutorado em Ciências IPEN/USP

INSTITUTO FEDERAL DE

EDUCAÇÃO, CIÊNCIA E TECNOLOGIA

TOCANTINS

Campus Palmas

\section{PERSPECTIVAS DE SUSTENTABILIDADE DA COMUNIDADE MATEIROS CONSIDERANDO $O$ POTENCIAL DE DESENVOLVIMENTO LOCAL POR MEIO DO TURISMO NA REGIÃO DO JALAPÃO}

QUESTIONÁRIO PARA A ENTREVISTA POR RESIDÊNCIA NA CIDADE DE MATEIROS/TO

№ do questionário

Nome do entrevistado

Data:

Entrevistador

\section{IDENTIFICAC̄̃̃O DO ENTREVISTADO}

1.1. Você trabalha com atividades ligadas ao turismo? ( ) Sim ( ) Não Em que?

1.2. Quantas pessoas da sua casa trabalham com atividades ligadas ao turismo?

1.3. Em que ano você começou a trabalhar nesta atividade?

1.4. Você trabalhava antes? ( 0 ) $\operatorname{sim}(1)$ não

1.5. Onde você mora? ( 0 ) na zona rural ( 1 ) no povoado ( 3 ) na cidade

1.6. Gênero: ( 1 ) masculino ( 2 ) feminino

1.7. Idade (anos)

1.8. Estado Civil

Antes: ( 0 ) solteiro(a) ( 2 ) viúvo(a) ( 1 ) casado(a) ( 3 ) união consensual Depois: ( 0 ) solteiro(a) ( 2 ) viúvo(a) ( 1 ) casado(a) ( 3 ) união consensual

1.9. Quantas pessoas moram na sua casa?

1.10. Tem filho(s) ? ( 0 ) sim ( 1 ) não

1.11. Quantos filhos você tem?

1.12. Qual a idade do(s) filho(s) ?

\section{QUALIDADE DE VIDA DO ENTREVISTADO}

(Situação do entrevistado antes e depois do turismo) 
I - Condições de Moradia

1.1. Situação de posse de sua residência

Antes: ( 0 ) alugada ( 1 ) cedida/doada ( 2 ) própria

Depois: ( 0 ) alugada ( 1 ) cedida/doada ( 2 ) própria

1.3. Tipo de construção do domicílio

Antes: ( 0 ) taipa ( 1 ) tijolo ( 2 ) tijolo/reboco

Depois: ( 0 ) taipa ( 1 ) tijolo ( 2 ) tijolo/reboco

1.4. Tipo de piso do domicílio

Antes: ( 0 ) barro ( 1 ) tijolo ( 2 ) cimento ( 3 ) cerâmica

Depois: ( 0 ) barro ( 1 ) tijolo ( 2 ) cimento ( 3 ) cerâmica

\subsection{Tipo de iluminação do domicílio}

Antes: ( 0 ) lamparina a querosene (velas) ( 1 ) lampião a gás ( 2 ) rede elétrica

Depois: (0) lamparina a querosene (velas) ( 1 ) lampião a gás ( 2 ) rede elétrica

1.6. Grau de satisfação das condições de moradia

ANTES ( 1 ) ruim ( 2 ) regular ( 3 ) bom

DEPOIS ( 1 ) ruim ( 2 ) regular ( 3 ) bom

\section{II - Aspectos Sanitários}

2.1. Destino dado aos dejetos humanos

Antes: ( 0 ) céu aberto ( 1 ) enterrado ( 2 ) fossa ( 3 ) rede de esgoto

Depois: ( 0 ) céu aberto ( 1 ) enterrado ( 2 ) fossa ( 3 ) rede de esgoto

2.2. Destino dado ao lixo domiciliar

Antes: ( 0 ) céu aberto ( 1 ) enterrado/queimado ( 2 ) coleta

Depois: ( 0 ) céu aberto ( 1 ) enterrado/queimado ( 2 ) coleta

2.3. Origem da água para consumo humano

Antes: ( 0 ) diretamente do rio/lagoa ( 1 ) poço ou cacimba ( 2 ) chafariz ( 3 ) rede pública 
Depois: ( 0 ) diretamente do rio/lagoa ( 1 ) poço ou cacimba ( 2 ) chafariz ( 3 ) rede pública

2.4. Tratamento dado à água para consumo humano

Antes: ( 0 ) não tratada ( 1 ) tratada (cloro, filtro, fervida)

Depois: ( 0 ) não tratada ( 1 ) tratada (cloro, filtro, fervida)

2.5. Grau de satisfação das condições sanitárias

ANTES ( 1 ) ruim ( 2 ) regular ( 3 ) bom

DEPOIS ( 1 ) ruim ( 2 ) regular ( 3 ) bom

\section{III - Bens de Consumo Duráveis}

3.1. Acesso a bens de consumo duráveis

Antes

GI $\left\{\begin{array}{l}\text { ( ) rádio ( ) ferro de passar ( ) liquidificador ( ) máquina de costura } \\ \text { ( ) fogão a gás ( ) geladeira ( ) televisão ( ) bicicleta ( ) aparelho de som }\end{array}\right.$ ( ) guarda-roupa ( ) ventilador ( ) cama ( ) outros (especificar)

G II ( ) antena parabólica ( ) DVD ( ) telefone ( ) motocicleta ( ) carro

Depois:

GI $\left\{\begin{array}{l}\text { ( ) rádio ( ) ferro de passar ( ) liquidificador ( ) máquina de costura } \\ \text { ( ) fogão a gás ( ) geladeira ( ) televisão ( ) bicicleta ( ) aparelho de som }\end{array}\right.$

( ) guarda-roupa ( ) ventilador ( ) cama ( ) outros (especificar)

G II ( ) antena parabólica ( ) DVD ( ) telefone ( ) motocicleta ( ) carro

Antes

( 0 ) Não possui nenhum dos bens acima citados

( 1 ) Possui pelo menos um dos bens do grupo 1 e nenhum do grupo 2

(2) Possui pelo menos um dos bens dos grupos 1 e 2

Depois

( 0 ) Não possui nenhum dos bens acima citados

(1) Possui pelo menos um dos bens do grupo 1 e nenhum do grupo 2

(2) Possui pelo menos um dos bens dos grupos 1 e 2 
3.2. Grau de satisfação em relação ao acesso a bens de consumo duráveis ANTES ( 1 ) ruim ( 2 ) regular ( 3 ) bom DEPOIS ( 1 ) ruim ( 2 ) regular ( 3 ) bom

\section{IV - Comunicação e Lazer}

4.1. Meio de comunicação (falada, escrita, televisionada e internet)

Antes

( 0 ) não escuta rádio, não lê revistas/jornais e nem assiste Tv

(1) escuta rádio, assiste Tv, mas não lê jornais e revistas

( 2 ) escuta rádio, assiste Tv e lê jornais e revistas

( 3 ) tem acesso à internet

Depois

( 0 ) não escuta rádio, não lê revistas/jornais e nem assiste Tv

( 1 ) escuta rádio, assiste Tv, mas não lê jornais e revistas

( 2 ) escuta rádio, assiste Tv e lê jornais e revistas

( 3 ) tem acesso à internet

4.2. Locais de lazer

Antes:

( 0 ) campo de futebol, centro comunitário, bares

( 1 ) seresta, grupo de dança

( 2 ) Ambientes naturais

( 3 ) outro(s) (especificar)

Depois:

( 0 ) campo de futebol, centro comunitário, bares

( 1 ) seresta, grupo de dança

(2) Ambientes naturais

( 3 ) outro(s) (especificar)

4.3. Grau de satisfação em relação ao acesso aos meios de comunicação e lazer ANTES ( 1 ) ruim ( 2 ) regular ( 3 ) bom

DEPOIS ( 1 ) ruim ( 2 ) regular ( 3 ) bom 
$\underline{\text { V-Saúde }}$

5.1. Prestação de serviços de saúde no bairro/comunidade

Antes

( 0 ) ausência de um posto de saúde

(1) atendimento por agente de saúde

(2 2 posto de saúde onde são oferecidos serviços básicos (primeiros socorros, vacinação)

( 3 ) existência de um posto de saúde equipado, oferecendo consultas e outros serviços

Depois:

( 0 ) ausência de um posto de saúde

( 1 ) atendimento por agente de saúde

(2 ) posto de saúde onde são oferecidos serviços básicos (primeiros socorros, vacinação)

( 3 ) existência de um posto de saúde equipado, oferecendo consultas e outros serviços

5.2. Grau de satisfação em relação aos serviços de saúde prestados

ANTES ( 1 ) ruim ( 2 ) regular ( 3 ) bom

DEPOIS ( 1 ) ruim ( 2 ) regular ( 3 ) bom

\section{$\underline{\text { VI - Educação }}$}

(entrevistado e sua família)

6.1. Você estudou até que série?

6.2. Quantos filhos estudam?

6.3. Grau de instrução do(s) filho(s)
( 0 ) pré-escolar
( 3 ) terceiro ano
( 6 ) sexto ano
( 9 ) nono ano
(1) primeiro ano
( 4 ) quarto ano
( 7 ) sétimo ano
( 10 ) ensino médio
( 2 ) segundo ano
( 5 ) quinto ano
( 8 ) oitavo ano

6.5. Grau de satisfação em relação ao nível de educação da família

ANTES ( 1 ) ruim ( 2 ) regular ( 3 ) bom

DEPOIS ( 1 ) ruim ( 2 ) regular ( 3 ) bom 


\section{VII - Emprego e Renda}

7.1. Que tipo de emprego você tinha?

7.2. Qual a renda da família?
Antes:
( 0 ) < 1 salário mínimo
( 1 ) 1 < 2 salários mínimos
( 2 ) 2 < 3 salários mínimos
( 3 ) > 3 salários mínimos
Depois:
( 0 ) < 1 salário mínimo
( 1 ) $1<2$ salários mínimos
( 2 ) 2 < 3 salários mínimos
( 3 ) > 3 salários mínimos

7.3. Das pessoas que moram na sua casa, quantas trabalham e qual a renda mensal de cada uma?

\begin{tabular}{|l|l|l|l|}
\hline Identificação & Idade & Ocupação / formal ou informal & Renda R\$ \\
\hline & & & \\
\hline & & & \\
\hline & & & \\
\hline & & & \\
\hline
\end{tabular}

7.4. Na sua casa, tem aposentado?

( 0 ) $\operatorname{sim}(1$ ) não Q Qual o valor (mensal)

7.5. Na sua casa, tem pensionista?

( 0 ) $\operatorname{sim}(1)$ não Qual o valor (mensal)

7.5. Na sua casa, tem pessoa que recebe auxílio do governo?

( 0 ) $\operatorname{sim}(1)$ não $\quad$ Bolsa Família (valor) Outros

7.6. Você tem algum tipo de imóvel (urbano ou rural) alugado?

( 0 ) $\operatorname{sim}(1)$ não Quantos? Desde quando? Valor do aluguel

7.7. Você recebe alguma ajuda em dinheiro de (filho, genro, primo, ou outro parente ou amigo que mora fora do domicílio)? Anotar o valor recebido por mês e desde quando e verificar se a origem está relacionada à atividade turística.

( 0 ) $\operatorname{sim}(1)$ não Quanto (valor mensal) ? Desde quando? 
7.8. Você já participou de algum curso de qualificação?

( 0 ) $\operatorname{sim} \quad$ (1) não Qual:

7.9. Participa de alguma associação ou cooperativa?

( 0 ) $\operatorname{sim} \quad$ (1) não Qual:

7.10. Qual o grau de satisfação com o desempenho da associação ou cooperativa?

( 0 ) Ruim (1) Regular ( 2 ) Bom

VIII - Meio Ambiente

8.1. Que situações são percebidas com relação ao meio ambiente:

( ) Queimadas e desmatamentos são responsáveis pela degradação ambiental.

( ) A exploração das atividades turísticas tem agredido o ambiente natural local.

( ) Agricultura e pecuária são atividades que degradam o ambiente.

( ) A exploração de espécies compromete o equilíbrio ambiental local.

( ) A exploração mineral é uma atividade impactante na região.

( 0 ) Marcou três ou mais itens ( 1 ) Marcou até dois itens

( 3 ) Não assinalou nenhum item

8.2. Qual o seu grau de satisfação em relação a preservação do meio ambiente local?
( 0 ) Ruim
(1) Regular
( 2 ) Bom 


\section{APÊNDICE E - Questionário Prefeitura/NATURATINS - Pegada Ecológica do} Turismo
ipen
Doutorado em Ciências IPEN/USP

\section{QUESTIONÁRIO PREFEITURA - NATURATINS}

Nome do entrevistado:

Cargo / Função:

Data da entrevista:

1- Quantas pousadas e campings Mateiros tem cadastrado? E quais são?

2- As pousadas e campings preenchem a FICHA NACIONAL DE REGISTRO DE HÓSPEDE?

3- Quantos turistas visitaram o Jalapão nos anos:

\begin{tabular}{|l|l|l|}
\hline \multicolumn{1}{|c|}{ ANO } & ALTA TEMPORADA & BAIXA TEMPORADA \\
\hline 2013 & & \\
\hline 2014 & & \\
\hline 2015 & & \\
\hline
\end{tabular}

4- Quantos dias em média o turista que viaja para o Jalapão fica na região?

5- Quais as dez principais nacionalidades de turistas que visitam o Jalapão? 
6- Quais as principais origens (cidades) dos turistas do Jalapão?

7- Qual a forma mais utilizada pelos hóspedes para chegar ao Jalapão:
6.1 - ( ) Avião via Palmas
6.2 - ( ) Carro

8- No caso da resposta 6.1, qual a forma que eles utilizam para chegar até Mateiros:

( ) Aluguel de carro

( ) Operadoras de turismo
( ) Vans

( ) Outros: 


\section{APÊNDICE F - Questionário Pousada/Camping - Pegada Ecológica do Turismo}

ipen

Doutorado em Ciências IPEN/USP

INSTITUTO FEDERAL DE

EDUCAÇÃO, CIÊNCIA E TECNOLOGIA

TOCANTINS

Campus Palmas

\section{QUESTIONÁRIO POUSADA E CAMPING}

Nome da Pousada / Camping:

Nome do entrevistado:

Cargo / Função:

Data da entrevista: Leitos:

1- Vocês possuem a FICHA NACIONAL DE REGISTRO DE HÓSPEDE?

2- Quantos turistas ficaram hospedados em seu empreendimento nos anos:

\begin{tabular}{|l|l|l|}
\hline \multicolumn{1}{|c|}{ ANO } & ALTA TEMPORADA & BAIXA TEMPORADA \\
\hline 2013 & & \\
\hline 2014 & & \\
\hline 2015 & & \\
\hline
\end{tabular}

3- Quantos dias em média o turista que viaja para o Jalapão fica na região?

4- Quais as dez principais nacionalidades de turistas que visitam o Jalapão?

5- Quais as principais origens (cidades) dos turistas do Jalapão? 
6- Qual a forma mais utilizada pelos hóspedes para chegar ao Jalapão:

6.1 - ( ) Avião via Palmas 6.2 - ( ) Carro

7- No caso da resposta 6.1, qual a forma que eles utilizam para chegar até Mateiros:

( ) Aluguel de carro

( ) Vans

( ) Operadoras de turismo

( ) Outros: 


\section{REFERÊNCIAS BIBLIOGRÁFICAS}

AGOSTINHO, F; PEREIRA, L. Support area as an indicator of environmental load: comparison between embodied energy, ecological footprint, and emergy accounting methods. Ecological Indicators. v. 24, pag. 494-503, 2013.

ALBERTI, V. Manual de História Oral. Rio de Janeiro: Editora FGV, 2004.

ANDRADE, C.S.; SILVA, A.P.; SILVA, A.P.; PINTO, R. Qualidade ambiental e saúde da população em Canavieiras - Bahia: Aspectos epidemiológicos de saneamento básico e prevalência de Parasitoses numa reserva extrativista. Revista Baiana de Saúde Pública. v.37, n. 2, p. 335-349, abr.-jun.2013.

ANDRADE, B.B; VAN BELLEN, H.M.; SANTOS, T.I. A sustentabilidade ecológica do sistema urbano de Florianópolis: uma aplicação do método da pegada ecológica. In: 58 Reunião Anual da SBPC, 2006, Florianópolis.

AQUINO, A.R.; ALMEIDA, J.R.; SENNA, M.L.G.S; DUTRA, V.C. Indicadores de desenvolvimento sustentável: uma visão acadêmica. 1. ed. - Rio de Janeiro: Rede Sirius; OUERJ, 2014.

AQUINO, A.R; PALETTA, F.C; CAMELLO, T.C.F; MARTINS, T. P.; ALMEIDA, J.R. Sustentabilidade Ambiental. 1. ed. - Rio de Janeiro: Rede Sirius; OUERJ, 2015.

BAQUERO, M. Avaliando o potencial de fatores culturais na construção da democracia na América Latina: uma comparação entre 2005 e 2010. Revistas Debates. Porto Alegre, v. 6, n.1, p.9-13, jan-abr 2012

BENI, M.C. Como certificar o turismo sustentável? Turismo em Análise, v. 14, n. 2, pag. 5-16. Novembro, 2003.

BRANDÃO, C.N.; BARBIERI. J.C.; REYES-JUNIOR, E. Desenvolvimento sustentável e turismo indígena: uma análise das oportunidades e limitações do turismo nas comunidades indígenas da Reserva São Marcos (RR). Revista Brasileira de Ecoturismo, São Paulo, v.6, n.1, jan/abr-2013.

CAMARGO, Luan José Jorge et al. Análise da sustentabilidade do turismo ecológico no município de Bonito, Mato Grosso do Sul na promoção do desenvolvimento regional. Soc. nat. (Online) [online]. 2011, vol.23, n.1, pp. 6575. ISSN 1982-4513.

CAMPOS, A. M. N. O ecoturismo como alternativa de desenvolvimento sustentável. Caderno Virtual de Turismo - IVT, n. 15. Laboratório de Tecnologia e Desenvolvimento Social - LTDS, Universidade Federal do Rio de Janeiro UFRJ, Fundação Carlos Chagas Filho de Amparo à Pesquisa do Estado do Rio de Janeiro - FAPERJ: Março, 2005.

CASTELLANI, V.; SALA, S. Ecological footprint and Life Cycle Assessment in the sustainability assessment of tourism activities. Ecological Indicators. v.16, pág. 135-147, 2012. 
CERVO, Amado; BERVIAN, Pedro. A. Metodologia científica. 4. ed. São Paulo: Makron Books, 1996.

CIDIN, R.C.P.J; SILVA, R.S. Pegada Ecológica: instrumento de avaliação dos impactos antrópicos no meio natural. Estudos Geográficos, Rio Claro, 2 (1), p. 43-52, jun 2004.

COBBINAH, P.B. Contextualising the meaning of ecotourism. Tourism Management Perspectives. v.16, pag. 179-189, 2015.

CUNHA, Sieglinde Kindl da; CUNHA, João Carlos da. Competitividade e sustentabilidade de um cluster de turismo: uma proposta de modelo sistêmico de medida do impacto do turismo no desenvolvimento local. Rev. adm. contemp. [online]. 2005, vol.9, n.spe2, pp. 63-79. ISSN 1982-7849.

DRUMMOND, José Augusto. Desenvolvimento sustentável: debates em torno de um conceito problemático. Hist. cienc. saude-Manguinhos, Rio de Janeiro, v. 5, n. 3, p. 755-761, Feb. 1999. Disponível em: <http://www.scielo.br/scielo.php?script=sci_arttext\&pid=S0104-

$59701999000100012 \&$ Ing=en\&nrm=iso >. Accesso em 24 de Setembro de 2015.

DUTRA, V.; COLARES, A.; ADORNO, LFM; MAGALHÃES, K; GOMES, K. Proposta de estrada-parque com unidade de conservação: dilemas e diálogos entre o Jalapão e Chapada dos Veadeiros. Sociedade \& Natureza. Uberlândia, 20 (1) 161-176, jun. 2008.

ELSASSER, H.; BURKI, R. Climate change as a threat to tourism in the Alps, Climate Research, v. 20, p. 253-257. 2002.

FEITOSA, M.J.S.; GOMEZ, C.R.P. Aplicação do Tourism Ecological Footprint Method para avaliação dos impactos ambientais do turismo em ilhas: um estudo em Fernando de Noronha. Rev. Brasileira de Pesquisa em Turismo. São Paulo, v. 7, n. 2, maio-ago de 2013.

FERREIRA, M.N.; REIS, E.S.; ADORNO, L.F.M. Caracterização dos impactos do uso público no Parque Estadual do Jalapão. In: V Congresso Brasileiro de Unidades de Conservação, 2007, Foz do Iguaçu. Anais do V Congresso Brasileiro de Conservação. Curitiba: Fundação O Boticário, 2007.

GESTO, Gestão das Unidades de Conservação do Tocantins. Disponível em: <http://gesto.to.gov.br/uc/45/> Acessado em 14 de maio de 2016.

GIATTI, L.L.; CUTOLO, S.A. Acesso à água para consumo humano e aspectos de saúde pública na Amazônia Legal. Revista Ambiente e Sociedade. São Paulo, v. XV, n.1, pag. 93-109, jan.-abr. 2012.

GOELDNER, C.R., RITCHIE, J.R.B., MCINTOSH, R.W. Turismo - Princípios, Práticas e Filosofia. Porto Alegre: Editora Bookman, 8ª Ed. 2002. 
GÖSSLING, S.; HANSSON, C.B.; HÖRSTMEIER, O.; SAGGEL, S. Ecological footprint analysis as a tool to assess tourism sustainability. Ecological Economics, v. 43, pag. 199-211, 2002.

HUNTER, C.; SHAW, J. The ecological footprint as a key indicator of sustainable tourism. Tourism Management. v.28, pag. 46-57, 2007.

IBGE. Instituto Brasileiro de Geografia e Estatística. Censo 2010. Cidades. Mateiros/TO. Disponível em:

http://cidades.ibge.gov.br/xtras/temas.php?lang=\&codmun=171270\&idtema=105\& search=tocantins|mateiros|censo-demografico-2010:-resultados-da-amostraeducacao--> Acessado em agosto de 2015.

IBGE. Instituto Brasileiro de Geografia e Estatística. Censo 2015. Cidades. Mateiros/TO. Disponível em:

http://cidades.ibge.gov.br/xtras/perfil.php?lang=\&codmun=171270\&search=||infogr \%E1ficos:-informa\%E7\%F5es-completas> Acessado em 15 de janeiro de 2016.

ICMBIO. Instituto Chico Mendes. Projeto Corredor Ecológico Região do Jalapão. Cartilha Informativa do Projeto Corredor Ecológico da Região do Jalapão. Disponível em:

http://www.icmbio.gov.br/projetojalapao/images/stories/publicacoes/folder_projeto _final.pdf> Acesso em: 08 de agosto de 2016.

IGAMI, M.P.Z.; ZARPELON, L.M.C. (Org). Guia para a elaboração de dissertações e teses: preparado para orientação dos alunos de Pós-graduação do IPEN. São Paulo: IPEN, Divisão de Informação e Documentação Científicas, 2002. Disponível em: <http://www.ipen.br/biblioteca/apresentacao_guia.htm>. Acesso em: 18 de agosto de 2015.

INACIO, S.A. Importância da estatística para o processo de conhecimento e tomada de decisão. Revista Paranaense de Desenvolvimento, Curitiba, n. 118, jan/jun 2010.

INFRAERO. Aeroportos Brasileiros. Aeroporto de Palmas Brigadeiro Lysias Rodrigues.

Disponível

em:

$<$ http://www.infraero.gov.br/index.php/aeroportos/tocantins/aeroporto-depalmas.html> Acesso em: Outubro de 2015.

JANNUZZI, P.M. Indicadores para diagnóstico, monitoramento e avaliação de programas sociais no Brasil. Revista de Serviço Público, Brasília. v. 56, n. 2, Abr-Jun 2005.

KEINERT, T.M.M.; KARRUZ, A.P.; KARRUZ, S.M. Sistemas locais de informação e a gestão pública da qualidade de vida nas cidades. Terra Livre, São Paulo, v.l, n.18, jan-jun/2012.

KIM, K.; UYSAL, M.; SIRGY, M.J. How does tourism in a community impact the quality of life of community residents? Tourism Management. v.36, 2013. 
LEHMANN, E.L., Nonparametrics: Statistics methods based on ranks, 1975.

LIMA, E.S., Impactos Socioeconômico Estuário Jaguaribe. Universidade Federal do Ceará. Centro de Ciências Agrárias. Departamento de Economia Agrícola. Projeto de Dissertação. Fortaleza: 2003.

LIMA, M.B; RIBEIRO, E.L. Diretrizes urbanísticas e construtivas para cidades de clima semiárido. PARC: Pesquisa em Arquitetura e Construção, v.1, p. 1-22, 2009.

MACHADO, A. Ecoturismo: Um Produto Viável. Rio de Janeiro: SENAC, 2005.

MAGALHÃES, K.A.; COTTA, R.M.M.; MARTINS, T.C.P.; GOMES, A.P.; SIQUEIRA-BATISTA, R. A habitação como determinante social da saúde: percepções e condições de vida de famílias cadastradas no Programa Bolsa Família. Revista Saúde e Sociedade. São Paulo, v.22, n.1, p. 57-72, 2013.

MARZALL, K., ALMEIDA, J. O Estado da Arte sobre indicadores de sustentabilidade para agroecossistemas. In: Seminário Internacional sobre Potencialidade e Limites do Desenvolvimento Sustentável. Santa Maria, RS: Universidade Federal de Santa Maria, 1999.

MATIAS, V.R.S.; MATOS, R.E.S. A geografia das tecnologias da informação e comunicação no Brasil contemporâneo. Caminhos da Geografia. Uberlândia. v.14; n.48, p.01-13, dez-2013.

MENON, M. G. K.. O que a ciência pode fazer pelo desenvolvimento sustentável? Estud. av. [online]. 1994, vol.8, n.20, pp. 10-14. ISSN 1806-9592.

MESSETTI, P.H.S.; SENNA, M.L.G.S.; AQUINO, A.R. Sustainable perspectives and Local Development Potential through Tourism. International Journal of Social, Behavioral, Educational, Economic and Management Engineering Vol:9, No:8, 2015.

MINAYO, Maria Cecília de Souza et. al. Qualidade de vida e Saúde. Revista Ciência e Saúde Coletiva, Rio de Janeiro, v. 5, n. 1, p. 7-18, 2000.

MINISTÉRIO DA CULTURA. Fundação Cultural Palmares. Portaria Interna no 06, de 01 de março de 2004. Certidão de auto reconhecimento. Brasília: 2006.

MOKFA, J. Qualidade de vida da cidade de Mateiros. [fev. 2014]. Entrevistadora Mary Lúcia Gomes Silveira de Senna. Entrevista com Prefeito da cidade de Mateiros. Pesquisa de campo para tese de doutorado, 2014.

MONTE, F. S. S.; REIS, J. N. P.; PAULA, L. A. M. de; CASTRO JÚNIOR, J. L. Qualidade de vida em reassentamentos de populações rurais atingidas por obras de infra-estrutura: o caso do complexo industrial e portuário do Pecém - Ceará. In: XXXVII CONGRESSO BRASILEIRO DE ECONOMIA E SOCIOLOGIA RURAL, 1999, Foz do Iguaçu. O agronegócio do Mercosul e a sua inserção na economia mundial. Brasília: SOBER, 1999. 
MTUR - Ministério do Turismo. Ecoturismo: orientações básicas. / Ministério do Turismo, Secretaria Nacional de Políticas de Turismo, Departamento de Estruturação, Articulação e Ordenamento Turístico, Coordenação Geral de Segmentação. - Brasília: Ministério do Turismo, 2008.

MTUR - Ministério do Turismo. Disponível em: <http://www.turismo.gov.br/ultimas-noticias/3586-aeroportos-registram-recordede-passageiros-no-pais.html> Acessado em 18 de agosto de 2014.

MTUR, Ministério do Turismo. Sistema Brasileiro de Classificação de Meios de Hospedagem. 2016.2 Disponível em: < http://www.classificacao.turismo.gov.br/MTUR-classificacao/mtursite/Entenda?tipo=6> Acessado em 11 de fevereiro de 2016.

MUNCK, L.; BORIM-DE.SOUZA, R. compreensão do desenvolvimento sustentável a partir do estabelecimento de tipos ideais. O\&S - Salvador, v. 20, n. 67, p. $651-674,2013$.

MUNDAY, M.; TURNER, K.; JONES, C. Accounting for the carbon associated with regional consumption. Tourism Management. v.36, pag. 35-44, 2013.

NAHAS, M.I.P. Sistemas de indicadores municipais no Brasil: enfoques conceituais, espaciais e metodológicos envolvidos na mensuração e monitoramento da qualidade de vida urbana para formulação de políticas públicas. Anais. XI Encontro Nacional da Associação Nacional de Pós-graduação e Pesquisa em Planejamento Urbano e Regional - ANPUR. Salvador, BA, 2005.

NAKAJIMA, E.S.; ORTEGA, E. Carrying capacity using emergy and a new calculation of the ecological footprint. Ecological Indicators. v.60, pág. 12001207, 2016.

NASCIMENTO, E. P. Trajetória da sustentabilidade: do ambiental ao social, do social ao econômico. Rev. Estudos Avançados, v. 26, n. 74, 2012.

NATURATINS - Instituto Natureza do Tocantins. Registro de visitantes das Dunas do Parque Estadual do Jalapão 2014. Entrevista com gestor do Parque em Fevereiro de 2015.

OLIVEIRA, Ermelinda e MANSO, José R. Pires. Turismo sustentável: utopia ou realidade? Tékhne [online]. 2010, n.14, pp. 235-253. ISSN 1645-9911.

ONU - Conferência das Nações Unidas sobre Meio Ambiente e Desenvolvimento (Agenda 21), 1992.

ONU - Indicadores para o desenvolvimento sustentável das Nações Unidas, 1996.

Disponível

em:

<http://www.un.org/esa/sustdev/natlinfo/indicators/isdms2001/table_4htm> Acessado em 15 de abril de 2013. 
PARENTE, T. G. Sentimentos e ressentimentos de Eva, uma mulher de vida livre. In: ERTZOGUE, M. H. e PARENTE. T. G. História e Sensibilidade. Brasília: Paralelo 15, 2006.

PEARCE, D.G. Geografia do turismo: fluxos e regiões no mercado de viagens. São Paulo: Aleph, 2003.

PEREIRA, F.A.; BELTRÃO, S.L.L. Democratização da ciência: uma política pública necessária para o desenvolvimento sustentável. Anais. IN: ENCONTRO DA REDE DE ESTUDOS RURAIS, 2., 2007, Rio de Janeiro. Tecendo o intercâmbio: o desafio do conhecimento sobre o mundo rural: anais. Rio de Janeiro: FEAGRI, 2007.

PIRES, A.L.C.S.; OLIVEIRA, R. de. Notas etnográficas sobre as comunidades negras rurais do Tocantins. PIRES, A.L.C.S.; OLIVEIRA, R. de. (Orgs). In: Sociabilidades Negras - Comunidades Remanescentes, Escravidão e Cultura. Editora: Editora Gráfica Daliana Ltda., Belo Horizonte, 2006.

PNUD. Evolução do IDH-M - municípios com menos de $\mathbf{5 0}$ mil habitantes. Atlas Ipea, 2006.

PNUD - Programa das Nações Unidas para o Desenvolvimento. Relatório Nacional de Acompanhamento dos Objetivos de Desenvolvimento do Milênio. 2013.

PNUD - Programa das Nações Unidas para o Desenvolvimento. Sobre o PNUD. Disponível em: < http://www.pnud.org.br/sobrepnud.aspx> Acessado em: 15 de novembro de 2015.

PORTELLI, Alessandro. História oral como gênero. In: Revista do Programa de Estudos pós-graduados em História e do Departamento de História História e Oral - Projeto História, n. 22, São Paulo: PUC-SP, junho 2001.

RODRIGUES, Ana Paula; VIEIRA, Isabel; MARQUES, Carlos Peixeira; TEIXEIRA, Mário Sérgio. Apoio da comunidade residente ao desenvolvimento turístico sustentável: um modelo de equações estruturais aplicado a uma cidade histórica do Norte de Portugal. TMStudies [online]. 2014, vol.10, n.2, pp. 17-25. ISSN 2182-8458.

SANTOS, EG; ARMOND, FN; NUNES, IH; SENNA, MLGS; MORAIS, PB, PARENTE, T.; RODRIGUES, W. Sustentabilidade e desenvolvimento local: A comunidade de Mumbuca e o Turismo na região do Jalapão. OLAM (Rio Claro), v. 7, p. 242-261, 2007.

SCHIMIDT, I. B. Etnobotânica e Ecologia populacional de Syngonanthus nitens: sempre viva utilizada para artesanato no Jalapão, Tocantins. Dissertação de mestrado em Ecologia da Universidade de Brasília. Brasília: 2005. 
SECOM, Secretaria da Comunicação do Tocantins. Com Turismo e Agricultura, renda média de Mateiros cresce $\mathbf{1 . 6 6 7 \%}$ em dez anos, diz Estadão. Disponível em: < http://secom.to.gov.br/noticia/50477/> Acesso em: Outubro de 2015.

SENNA, M.L.G.S. Percepção e representação ambiental dos guias/condutores e dos turistas do Parque Estadual do Jalapão/TO, como fator influenciador da prática ecoturística. 2008, 115 f. Dissertação (Mestrado em Ciências do Ambiente) - Universidade Federal do Tocantins, Palmas, 2008.

SENNA, M.L.G.S.; DUTRA, V.C.; AQUINO, A.R. Methodologies for Management of Sustainable Tourism: A Case Study in Jalapão/Tocantins/Brazil. International Journal of Social, Behavioral, Educational, Economic and Management Engineering Vol:9, No:8, 2015.

SENNA, MLGS; MAGALHÃES, HGD. Os mitos do Fervedouro no Jalapão/TO. In: MAGALHÃES, HGD; PARENTE, T.G. (Orgs). Linguagens Plurais, Cultura e Meio Ambiente. Bauru, SP: EDUSC, 2008.

SEPLAN, Secretaria do Planejamento e Meio Ambiente. Plano de Manejo do Parque Estadual do Jalapão, 2003. Disponível em: <www.seplan.to.gov.br>. Acessado em: jun. 2006.

SICHE, R; AGOSTINHO, F; ORTEGA, E; ROMEIRO, A. Índices versus indicadores: precisões conceituais na discussão conceitual da sustentabilidade de países. Ambiente e Sociedade. Campinas. V.X, n. 2, pg. 137-148. Jul-dez 2007.

SILVA, F.D.; CARVALHO, F.C. Turismo em Favelas: O caso da comunidade de Santa Marta, Rio de Janeiro. Caderno de Pós-graduação em Arquitetura e Urbanismo. v. 14, n.1, 2014.

SILVA, E.A.P.C; SILVA, P.P.C; SANTOS, A.R.M; CARTAXO, H.G.O; RECHIA, S; FREITAS, C.M.S.M. Espaços públicos de lazer na promoção da qualidade de vida: uma revisão integrativa. Licere, Belo Horizonte, v.16, n.2, jun/2013.

SOARES, I.A.; MEDEIROS, C.S.C.; SALES FILHO, A. Análise de paisagens turísticas na praia de Jenipabu (CE) com a utilização de indicadores de qualidade visual: uma contribuição para o turismo sustentável. Caminhos da Geografia. Uberlândia. v.14, n.15, mar/2013.

SOARES JUNIOR, J.S. Instrumentalização do desenvolvimento: Teorias, Conceitos e Indicadores. O\&S. v. 15, n.45. Abr-Jun 2008.

SOUZA, R.A.; CARVALHO, A.M. Programa de Saúde da Família e qualidade de vida: um olhar da psicologia. Estudos de Psicologia, v.8, n.3, pág. 515- 23, 2003.

SOUZA, G.A.A.; MOREIRA-JUNIOR, J.C.; SANTOS, M.L.V.; MENDONÇA, R.S.; FARIAS, T.F.C.; MARQUES, M.R. Arquitetura da Terra: alternativa sustentável para os impactos ambientais causados pela construção civil. Revista E-xacta. v.8, n.1, 2015. 
TEIXEIRAS, M.F.F.B. Pegada Ecológica e Políticas Públicas: estudo de caso de três cidades brasileiras. Revista Iberoamericana de Economia Ecológica. Vol. 19, pg. 15-28, 2012.

TOLEDO, C. Portal Cleber Toledo. Após ter sido provocado na Justiça, Estado regulariza fornecimento de água tratada em Mateiros. Disponível em: $<$ http://www.clebertoledo.com.br/estado/2015/07/06/70712-apos-ter-sidoprovocado-na-justica-estado-regulariza-fornecimento-de-agua-tratada-emmateiros> Acessado em: 15 de outubro de 2015.

TOCANTINS, Guia Turístico do Tocantins: Ecológico, Histórico e Cultural. Brasil. São Paulo. Empresa das Artes, 2011.

UNEP - United Nations Environment Programme. Tourism's Three Main Impact Areas. Disponível em: $<$ http://www.unep.org/resourceefficiency/Business/SectoralActivities/Tourism/Facts andFiguresaboutTourism/ImpactsofTourism/Environmentallmpacts/TourismsThree MainlmpactAreas/tabid/78776/Default.aspx> Acessado em: 15 de agosto de 2015.

UNWTO - World Tourism Organization - Tourism Highlights, 2015 Edition. 2015. Disponível em: <http://www.e-unwto.org/doi/pdf/10.18111/9789284416899> Acessado em: 30 de setembro de 2015.

UYSAL, M.; SIRGY, M.J.; WOO, E. KIM, H. Quality of life (QOL) and well-being research in tourism. Tourism Management. p. 1-18, 2015.

VEIGA, J. E. Desenvolvimento sustentável: o desafio do século XXI. Rio de Janeiro: Garamond, 2005.

WEAVER, D.B. Ecotourism as Mass Tourism: Contradiction or Reality? The Cornell Hotel and Restaurant Administration Quarterly. v.42, n. 2, April 2001.

WEAVER, D. Sustainable Tourism: Theory and Practice. BUTTERWORTH HEINEMANN, 2005. ISBN: 978-0-7506-6438-7

WESTPHAL, M.F. O Programa de Saúde da Família: um compromisso com a qualidade de vida. SANARE - Revista de Políticas Públicas. ANO IV, N.1, JAN./FEV./MAR. 2003.

WWF. World Wildlife Fund). Relatório Planeta Vivo: biodiversidade, biocapacidade e desenvolvimento. Disponível em: <http://www.wwf.org.br/natureza_brasileira/especiais/relatorio_planeta_vivo/> Acessado em: 15 de novembro de 2015. 